

\section{U. C. L. A. EDUC. DEPT,}

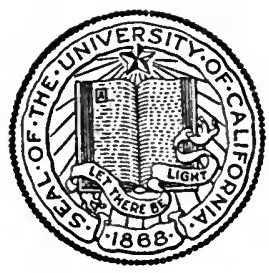

THE LIBRARY

OF

THE UNIVERSITY

OF CALIFORNIA

LOS ANGELES 
Digitized by the Internet Archive in 2007 with funding from Microsoft Corporation 



\section{Studies in the History of Educational Opinion from the Renaissance}




\section{7london: C. J. CLAY AND SONS, CAMBRIDGE UNIVERSITY PRESS WAREHOUSE, AVE MARIA LANE. \\ Blaggón: 5o, WELLINGTON STREET.}

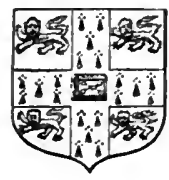

Zlipsig: F. A. PROCKHAUS.

Pew Gork: THE MACMILLAN COMPANY.

Bombay and ealcutta: MACMILLAN AND CO., LTD. 


\title{
Studies in the History of Educational Opinion from the Renaissance
}

\author{
By \\ S. S. Laurie, A.M., Ll.D. \\ Professor of the Institutes and \\ History of Education, University of Edinburgh.
}

Cambridge :

at the University Press.

$$
\begin{aligned}
& \text { U. C. } C^{190}\{\text {. A. } \\
& \text { EDUC. DEPT, }
\end{aligned}
$$




\section{Cambridge:}

PRINTED BY J. AND C. F. CLAY, AT THE UNIVERSITY PRESS. 


\section{U. C. L. A. EDUC. DEPT,

\section{PREFATORY NOTE.}

I VENTURE to issue these Lectures in the conviction that 1 the study of the History of Education in the writings of the most distinguished representatives of various schools of thought is an important part of the general preparation of those who adopt the profession of Schoolmaster. To present a general historical outline of opinion I have found in practice to be uninstructive as compared with an analytic exposition of the doctrines of eminent writers themselves. At the same time, the leading characteristics of the historical development have to be indicated.

To deal with the whole question of education during the period of transition from the scholastic philosophy and monastic and cathedral schools down to these times or even to 1600 , which may be regarded as the beginning of the Modern period, is beyond my power. And even if I had the necessary learning, I doubt if by so doing I would serve the purpose I have in view so well as by selecting representative 
men and interesting students of education in their methods. For my purpose is the education of those who mean to devote their lives to education.

The student, who adds to a study of this volume the accounts of Rousseau, Pestalozzi and Froebel in Quick's Educational Biographies and some good exposition of Herbart, will have a very fair acquaintance with the main lines of educational opinion since the Renaissance.

I would apologise for the large space I give to Locke, did I not think that his Thoughts read along with his Conduct of the Understanding is, spite of some obvious faults, the best treatise on education which has ever appeared with the (doubtful) exception of Quintilian.

$$
\text { S. S. I. }
$$

\section{UXIVERSITY OF EDINBURGH,}

December 1902.

NoTE. Four of the sixteen chapters of this volume have appeared in books now for some time out of print. 


\section{CONTENTS.}

CHAPTER

PAGE

I. The Renaissance, 1320-1600 . . . . . 3

II. The Renaissance and the School-First Period (1320-1450). Vittorino da Feltre, 1378-1446 . is

III. The Second Period of the Renaissance (I450-I600). Trotzendorf; Sturm; Neander . . . . 24

IV. Universities ..$\quad \cdot \quad \cdot \quad \cdot \quad \cdot \quad \cdot 3 \mathrm{I}$

V. "The Governour," by Sir Thomas Elyot ; ? 1490-1546 38

VI. Rabelais: Monk, Physician, Curé of Meudon. 1483(?)-1553. Note on Erasmus; I466-1536 (p. 55) . . . . . . . . . . 46

VII. Roger Ascham, the Humanist; 1515-1568. . 58

VIII. The Jesuits. Order founded I534 • • • . 86

IX. Montaigne, the French Rationalist, I 533-I 592 . 94

The Modern Period, from 1600 A.D.

X. Francis Bacon, 1561-1626. . . . . . 119

XI. Comenius, the Sense-Encyclopaedist and Founder of Method; 1592-167I . . . . . . 138

XII. John Milton, the Classical Encyclopaedist ; 1608 1674 . . . . . . . . . 159

XIII. John Locke, the English Rationalist ; 1632-1704 . 18 I XIV. John Locke-continued • • • . . . 208

XV. John Locke-concluded. "The Conduct of the Understanding" . . . . . . . 222

XVI. Herbert Spencer, the modern Sense-Realist . . 235 

"THE RENAISSANCE AND THE SCHOOL." 



\section{CHAPTER I.}

THE RENAISSANCE, I320-I600.

First Period, 1320-1450.

Second Period, 1450-1600.

THE Renaissance, or the Revival of Letters, is the name by which we distinguish the period which saw the revolt of the intellect of Europe against Mediaevalism in all its forms, political, ecclesiastical, philosophical, and literary. It has correctly enough been called a 'Humanistic' revival; but the word 'Humanistic,' if it is to be a true designation, must be interpreted broadly and not confined to the revived interest in Litterae Humaniores.

The revival, indeed, was inevitable from the day on which the intellect of Europe had built for itself a house to live in, and put on the roof, and made fast the doors. Thought on moral and religious questions had on certain lines exhausted itself and been rounded off, after having been organized into a system, provided with administrators and guarded by penalties. Of the Church Secular, the Church Monastic, and of Civil Polity this is true. Nay, of the Universities, presumed to be the centres of a living intellectual activity-the mind of Europe-it was also substantially true, from I 200 A.D. till the time of Descartes. The great organizing intellect of the Middle 
Ages was St Thomas Aquinas, who died in 1272 . The disputations, which gave zest to Academic life for centuries before and after St Thomas, contained, many of them, grave issues; but they were all within certain recognized authoritative lines. And even where they raised questions that might have called forth answers fatal to the prevalent theological system, these were often discussed as matters purely intellectual, which, however they might be settled in the dialectical arena, could not disturb the dogmas of Faith. Even after the Revival was in full swing, doctors had, not seldom, one opinion for philosophic schools, another for the Church and the world outside. They were scarcely honest, as we now count honesty; but intellectual honesty is in these days a cheap virtue; and yet, spite of this, a good many think it even now too dear at the price to be paid for it.

The House which mediaeval faith, scholastic philosophy and ecclesiastical administrative genius had built for itself, was, because of its very completeness, a prison. Perhaps it may safely be said that there is no possible organized system of thought and life, which could sustain for long its despotism over the mind of the higher races of men. Reason is in its essence free, and will always react against uniformity of opinion and custom. It is a disruptive force. The laying of the last stone of a temple is the beginning of its decay.

At the same time let us note this fact, that had it not been for the freedom of discussion inevitably connected with the mediaeval Universities from the i ith century onwards, the mind of Europe would not have been prepared for any new advance. The scholastic disputations and the revival of Hellenic abstract thought, while they gave form and stability to Catholic doctrine, yet stirred a speculative spirit which went far beyond the limits which the Church would have prescribed. We see this spirit operating as early as Abelard. The Hellenic literature and attitude to life was the great intellectual foe of the Church in the early centuries of the Christian era: again 
it intruded itself, and the conflict had to be renewed and is still progressing. It is, at bottom, a struggle between Naturalism in the broad Hellenic sense of that term and Supernaturalism. The former, while necessarily unstable, lends itself to progress ; the latter is, as authoritative, stable, and suspicious of all movement.

But there were other precursors of the Renaissance. The Crusades had disturbed the mind of Europe and brought nations into contact with each other. Above all, they had brought the more thoughtful and inquiring minds into touch with Byzantine and Arabic learning, which was itself in the direct line of Hellenic tradition. Secondly, the general rise of nationalities and the beginnings of national vernacular literatures were indications of a stirring of the mind of Europe of which it would be difficult to find an explanation. The national songs and poems which formed the basis of the Romance of the Cid in Spain (from II80 A.D. onward), the Chansons de Geste of a still earlier date, the Provençal poets, the Niebelunglied in Germany (1 $3^{\text {th }}$ century), the Scandinavian Sagas (from ninth century onwards), the Romance of Arthur among the Celts of England and its translation into English, the Romances (chief of which was Amadis of Gaul) were all unmistakable signs of the beginning of a way of looking at human life and of a free enjoyment of the human intellect in its own creations, which had little in common with the ecclesiasticism and monasticism of the ages prior to the I $3^{\text {th }}$ century ${ }^{1}$. It is probable, however, that the supreme agent in reinstating in man a belief in his natural powers was the intense intellectual activity at all University centres to which I have referred above, and which led to the raising of many questions which had been held to be finally settled. And

1 We get a very instructive account of the pre-Renaissance literary activity in Warton's History of English Poetry. 
to this we may add the order of Chivalry so closely associated with individual prowess and character. 'Thus Europe passed out of a period of dogmatic and ecclesiastical bondage into the freer life of the modern world by very gradual steps, and found itself unawares in a new intellectual attitude to life and possessed by a higher faith in human capacities and possibilities. This advance is correctly enough called the Renaissance.

The new movement ran in three main streams which had a common source, and that common source was simply Reason itself as a free, and even rebellious, activity. These streams were Art, Religion, and Science, or, to put it otherwise, life in life itself and nature-impelled by its fulness to seek the satisfaction of utterance in beautiful forms through the medium of language and the other materials and vehicles of artistic expression; a new and deeper sense of the personal and immediate relation of the spirit of man to the moral order and to God; and a pursuit of truth for its own sake. An immediate and fresh looking at man and human experience may be said to sum up the Revival. Thus we find living in the first period, Dante, Petrarch, Boccaccio, and Chaucer; and also Wykliffe, Huss, and Jerome of Prag. IVhen we consider the achievements of these men, and the still earlier vernacular literatures to which we have referred above, it is evident that the Renaissance was not dependent on the revival of Latin and Greek literature for its origin or its permanence.

It was, however, inevitable that in seeking for an expression of Life and Art, the more active minds should be drawn to what was ready-made, but had been forgotten. Latin literature and, subsequently, the study of Greek, accordingly, were the two great occupations of the Humanists. In the middle of the I $5^{\text {th }}$ century, says Hallam, "The spirit of ancient learning was diffused," on the Italian side of the Alps. "The Greek language might then be learned in four or five cities, and an acquaintance with it was a recommendation to the favour of the great; while the establishment of Universities at Pavia, 
Turin, Ferrara and Florence" (during the preceding generation) "bore witness to the generous emulation which they served to redouble and concentrate."-Hallam, 1. pt. I. ch. 2. Ambitious scholars from Northern lands visited Italy to participate in the new learning. Wessel was there in 1470 , Rudolf Agricola in 1476 .

It is correct to say that the first period of what is commonly known as the Renaissance was, to begin with, solely, and till towards the end of the $15^{\text {th }}$ century chiefly, Italian, whether we regard vernacular writings, the revived study of Latin and Greek literature, the growth of Art, or the reaction against mediaeval theology. Unfortunately, the new delight in literature, art, and a natural life, and the total breach with religious tradition, led to wide-spread scepticism and to a loosening of moral bonds. A life of pleasure and even of licence was characteristic of the time. Impatience with the theological conception of life took a negative character, and Christianity was nowhere at such a low ebb as in Rome and the other cities of Northern Italy.

The second period of the Revival may be dated from the fall of the Eastern capital ( 1453 ), and the consequent dispersion of Greek scholars. This gave fresh life to the pursuit of ancient learning, just as Hellenic studies received a great impulse in ancient Rome after the fall of Corinth. The invention of printing also was a vital factor in securing the diffusion and permanence of Humanism, while the invention of the mariner's compass had a potent effect in extending the world-view. For more than a century, before and after the above date, men occupied themselves chiefly with Hellenic and Roman literature. Thereafter, the slowly growing vernacular and original literatures of Europe began to take form, and gradually to oust the ancients from exclusive possession. These continued to hold the field only in the schools. Art in painting and architecture continued to share in the general reawakening.

The second stream of the rebirth, anticipated by Wykliffe 
Huss, and Jerome of Prag, was the Religious. In this field of thought, man longed to see through form, dogma and ritual into the realities of the life of the soul. The Humanistic movement was thus closely allied with the theological, north of the Alps. In Italy, theology had been abjured and moral laxity had been the result. North of the Alps, however, there was always present a genuine feeling for the spiritual life, although the Courts of Princes had been largely Italianized. A longing for 'reality' in divine things, as opposed to mere dogmatic form, was conspicuous in the Mystics and in such men as Wessel, of whom both Erasmus and Luther speak in laudatory terms. But prior to him, Florentius Radewin, with the consent of his master, Gerard Groote', had founded the "Brothers of the Common Life" (Hieronymians), whose governing idea was life rather than doctrine, and who allied their religious aims with a restricted humanistic study. Florentius died in 1400 , Wessel in 1489 , and Thomas à Kempis in $147 \mathrm{I}$. I name these men because the great intellectual and moral forces operating during the earlier portion of the second period are to be found chiefly north of the Alps, if we are to take a large view of the Renaissance. The pagan and unbelieving spirit among the Humanists of Italy was not shared by the Northern men. With them, Humanism and a reformed Theology based on the original Gospels went hand in hand. There was no separation of the Humanistic and the Religious revivals; nor indeed, when Humanism at its first dawn was recognized by Catholic prelates in Italy, was it ever imagined that there could be any necessary antagonism.

The houses and schools of the "brethren of the common life" spread throughout the Netherlands, Germany and France. The central motive-force was a religious one-an attempt to return to a simple New Testament life. They had, as I have said above, a tendency to Mysticism. They were in fact Mystics, in so far as subjective feeling and an intense personal experience

1 Born at Deventer $134^{\circ}$. 
arising out of this, as opposed to elaborate dogma, governed their Christianity. It was natural that such men should think more of the education of the mass of the people than dogmatists or the literary humanists could be expected to do. They welcomed humanistic learning certainly, but always as subordinate to the religious life; and, for a time, only in the restricted form of classical Latin and the literature of the Romans. Even in the struggles of the Reformation period, we find in Luther (d. 1546) and Melanchthon (d. 1560) the Humanistic and the Theological in perfect harmony. It has been usual to regard the more literary Erasmus, because he disapproved of some of Luther's methods and of his insistence on the doctrine of Justification by Faith alone, as a kind of literary sceptic, like the neo-pagan Italians. This accusation, it seems to me, is no more true of him than it would be if directed against his English friends Colet and Sir Thomas More. These men represented what in this country has been called evangelical Broad-Churchism, and worked in the genuine spirit of Protestantisn and of a spiritual Christianity. The moderation of Erasmus as contrasted with the fiery zeal of Luther does not detract from his earnestness. We find his humane and enlightened religious convictions stated in his Enchiridion and in his exquisite and sympathetic portraiture of the rare character of the Franciscan John Vitrarius'.

The third stream of the Revival was a Scientific streaman extended knowledge of the earth and inquiry into the causes of things. This followed the literary and religious. Advanced spirits began to study nature as a system of laws and to supersede scholastic and theological a priori constructions by knowledge based on the observation of facts. This and the extension of geographical knowledge profoundly affected

1 See Drummond's Life of Erasmus, cap. 1v. Also in his true "Method of Theology" in the Novum Testamentum. 
the world-view of all thinking men. Columbus, Galilei, Pomponazzi, Ludovicus Vives all belong to the second period.

The old order as represented by the Pope and Charles V. had now taken alarm and resisted all reform. The Church quickly gathered together its forces; and by the decrees of the Council of Trent and the activity of its agents everywhere and, with the help of the Jesuits (1540) and the Inquisition, made great way in recovering its hold on the rebellious mind of Europe. Humanism, the reformed religion, and national liberty had now all to fight for their existence against the principle of imperial absolutism supported by clerical absolutism centred in the Pope. The larger and more vital human interest necessarily obscured the lesser, and what concerned the life of the masses of the people dwarfed the claims of Humanism and culture which were for the few. Moreover, the example of Italy had shown the world that a society whose dominating idea was Art contained the germs of the decay of morals and of all manly virtues. Man does not live by bread alone,- that is to say, a material civilization: Italy placed it beyond all question that man cannot live by Art alone, however widely we interpret that word.

Protestant and Catholic alike, in strengthening their defences, had to surround themselves with the buttresses of dogma; and thus the reformed religion, while retaining at its heart the principle of freedom, yet narrowed itself to a stringent orthodoxy which was, and still is, wherever it exists, almost as great an enemy to the life and art and free philosophy that are the essential characteristics of pure Humanism as the mediaeval system was before it was put on its defence. With this new orthodoxy was inseparably bound up an earnest ethical spirit, the principles of civil and religious liberty, and the eternal interests of the individual. Where could literature and art find a footing in the face of such important political and tremendous personal issues? Those belong to the 'world'; 
and the true Christian, it was felt (as in the fourth century), can know nothing of them, or at best only play with them. We live in more fortunate times. The humanistic and the theological now respect each other's aims-the theological spirit having now accepted the best in literature and art and also that result of the Renaissance which we call science; and (what is of more importance), having become alive to fundamental questions, recognizing that these can only be answered by the help of a free philosophy and scientific investigation which shall unite religious thought with the humanistic and naturalistic theory of life. But the parallel streams have not yet wholly mingled their waters: that cannot happen until religion shall have been wholly humanised, and philosophy, literature and science have been in their turn consecrated.

In Italy we have, during this second period, in addition to those I have named, Pico, and his friends Politian and Ficino, and in the sphere of religion Savonarola (b. 1452); in Holland Erasmus, and in England his friends Grocyn, Linacre, Colet and More. Greek and a simpler theology than that of Aquinas had already established itself at Oxford, whither Erasmus came to extend his knowledge of it. In Germany we have, among others, Rudolf Agricola and Reuchlin; and in theology, the Mystics and Brethren of the Common Life, to whom I have already referred '

I am well aware that a brief survey of a great and complex historical movement is, simply because it is inadequate, to that extent inaccurate, but it is necessary to an intelligent comprehension of education as affected by the Renaissance that some such survey should be given. We may take the date of the death of Melanchthon ( 1560 ) as sufficiently well

1 Chiefly owing to the writings of the Neo-Platonist the pseudoDionysius Areopagiticus, mysticism had never died out during the Middle Ages; and, in truth, the writings of Dionysius taken along with those of St Augustine entered, though not so largely as the philosophy of Aristotle, into the work of the Schoolmen. 
indicating the period up to which the Religious Reformation and Humanism maintained a close alliance north of the Alps. The Humanism of the Reformation is, indeed, well represented by Melanchthon's text-books for school and college. To this date the Humanistic and Religious streams had not yet separated their waters. 'They now, however, began to diverge.

The Order of the Jesuits was founded in 1540 and flung down the gauntlet to Protestantism, while so far recognizing the modern spirit as to take up into its educational system as much of the new Humanism as was thought safe. Unfortunately, the reformers of Church and School were too exclusively occupied with the instruction in the evangelical faith of the masses of the people to institute any agency of secondary education capable of coping with the Jesuit organization. The Hieronymians, or a Protestant Order on the same basis, and with the same aims, could alone have done for modern ideas what the Jesuits did for mediaeval doctrine and papal supremacy. The scattered efforts of a great humanistic teacher here and there were helpless in the presence of an organized force, with an educational method, and backed by all the power of the Roman Catholic Church. They confined themselves to the education of the upper section of society, whilst the educational zeal of the Reformers, in perfect consistency with their point of view, expended itself (as I have indicated) chiefly on the common school and catechetical instruction. In the Universities the pervading influence was still theological and Aristotelian.

Classical Humanism had now reached the age of criticism and learned editions, culminating in those scholars, of whom the younger Scaliger and Casaubon may be regarded as principes. It is interesting to note in the divergent movements of religion and literature the same tendencies to criticism, revision and formulation after the first fervour had exhausted itself. And yet we may say that, down to about the 
year 1600 , Latin 'style' was still the mark of the humanistic man of culture, just as a genuine faith in the living substance, as opposed to the dogmatic form, of Christianity was still the mark of the reformed theologian.

The above brief survey will enable us to see how the study of language became the common bond between the literary and religious promoters of the Revival in the $15^{\text {th }}$ and 16 th centuries. A barbarous and monkish Latinity was the vehicle of a barbarous and monkish conception of life. We cannot separate Language and Thought. Hence the identification of the Humanistic Revival as Literary and Aesthetic with the study of Latin and Greek - the two great vehicles of literature and art common to the European world. Hence, too, the identification of the revival of a pure Christianity with the critical study of the same languages and of Hebrew. Latin and Greek literature contained models of literary excellence, while Greek and Hebrew contained the primitive record of a great historical faith. To understand the true significance of the faith it was necessary to understand the original records in which it was given first to the world. The great weapon against the religious corruptions of the time accordingly was the Bible and nothing but the Bible, and its interpretation in the spirit of antiquity and unencumbered by the dogmatism of the Church and the dialectic of the schoolmen. This was the teaching of the great Erasmus, who was less scholasic than Luther, but as genuinely Christian. Men had to receive the truths of God anew and to start afresh, as it were. Hence, we may here say, the necessity of always maintaining scholarship in a historical Church, if it is not to become an organ of ignorant fanaticism and alienate all save the unhistorical vulgar; nay, even because of its extravagances and superstitions, shut out the majority of reasonable men. In Philosophy, Literature, Art, Theology and, we may add, in Political Science also, we must ever and in all ages fall back on original sources, 
and be constantly bringing to light the primary significance of what has been achieved by our ancestors ; and this by a critical study not only of their language, but also of the conditions of past life. This, in fact, is History in its fundamental sense; and it will be granted universally that, if man is a progressive being, he must understand the steps of his past progress, or, failing this, go on repeating the barbarisms, not only of language, but of thought and life, which preceded the great intellectual epochs of the Hebrews, the Greeks and the Romans,-the nations which have laid the foundations of our modern political societies, our individual culture, our philosophies and our religious convictions.

Language, being thus the common bond of all the workers of the Renaissance period, we must not be surprised that in the education of youth it should itself have become an object of idolatry and ultimately also of well-deserved satire. This was one of the extravagances that attend all great movements, whether they be intellectual or aesthetic, political or religious. Note also that the idolatry of language was a restoration of the ideal of education of Roman imperial times, viz. Oratory. But we must never forget that the revival of Greek and Hebrew had other than literary objects in view. Reuchlin, in first introducing these languages into Germany, with his intense humanism and simple scriptural Christianity, truly prepared the way for Luther, by fixing attention on the original records, and thus on the true meaning of the documents on which the Church was founded.

It would be a great error, however, to suppose that the influence of the Renaissance on education was restricted to language. The Renaissance destroyed, as well as built up anew, in every department of education.

"The education of the Middle Ages," says Mons. Compayré, "once rigid and repressive, which condemned the body to a régime too severe and the mind to a discipline too narrow, is now to be followed (at least in theory) by an education broader 
and more liberal; which will give due attention to hygiene and physical exercises; which will enfranchise the intelligence hitherto the prisoner of the syllogism; which will substitute real studies for the verbal subtleties of dialectic; which will give the preference to things over words; which, finally, instead of developing but a single faculty, the reason, and instead of reducing man to a sort of dialectic automaton, will seek to develope the whole man in mind and body, taste and knowledge, heart and will" (p. 83).

The Humanism of Italy in the $15^{\text {th }}$ century gave Europe its new secondary school curriculum. Schoolmasters seem however never to have realized that the Humanistic school as originally conceived was much more than Humanistic; it was Renaissance. It embraced much more than grammar and,style. But even if we imitated the more eminent teachers of the 16 th century in the greater breadth of our curriculum, it would be a mistake to allow ancient languages to dominate the whole system as we have done hitherto. The Humanists educated the few: we have now to give the higher education to all above a certain age, and it is incumbent on us to remember this difference, and, in the light of it, to reconsider our educational instruments. And this we can do effectually only by considering the question of education itself-what it means, what it proposes to itself as aim. And this again must be considered in close relation to the environment and duties of modern nations. If we should come to the conclusion that the purpose of educating a human mind can after all, even in the 2 oth century, be best attained by bringing modern boys into a living acquaintance with the literature of Greece and Rome, then let us lay all our strength on this and try at last to succeed. We have as yet failed. I should like the Conference of Headmasters (confidentially) to tell the public how many boys are annually stirred by a line of Homer, touched by a line of Virgil, or led to appreciate eloquence by 
an oration of Cicero or Demosthenes. Whether from want of method or some other cause, failure is the one word that is applicable to what we call 'classical' education in the case of 95 per cent. of those who are said to have been 'put through' it. And as to the remaining 5 per cent. the educational result has in not a few cases been narrowness and pedantry and preciosity-the very negation of the true and living Renaissance spirit.

Personally I am disposed to think that there are no instruments that can compare with Latin and Greek literature if our purpose be culture. But to secure this result boys must, in the university, be fit to receive and in a position to continue the instruction which the school only begins. How many are fit to receive and what proportion of those who receive and respond are able, in face of the pressing demands of modern life, to acquire familiarity with the great masters of antiquity? Can we think of no other scheme of education which will conserve the past while fitting for the living present? Can we find no modern definition of Humanism ${ }^{1}$ ?

In the preceding pages I have endeavoured to give a brief and general survey of the Renaissance down to 1600 , and to indicate generally its relation to education in the larger sense. Our special business now is to speak of it solely in relation to the actual work of school and university; and this I shall best do by adverting, to begin with, to the first period of the Revival-1320-1450-and to the celebrated Italian school of Vittorino da Feltre, which led the way for all Europe in point of time at least, if not as a model.

Meanwhile let us note that we should expect to find in schools the fertilizing effects of what I have called the three streams of the Revival: the Literary, the Religious, and the Scientific.

1 The closing chapter of Professor Lodge's Close of the Middle Ages gives an excellent survey of the Renaissance Period, at once succinct and full. 
The restoration of antiquity gave the chief direction to the work of the secondary schools for obvious reasons. It was only at school and in the university that a knowledge of the ancients could be obtained. Latin and Greek had to be laboriously acquired, whereas the active-minded student could read his Dante and Petrarch and all vernacular contributions to literature without the help of masters. This theory of secondary instruction soon prevailed over all Europe, and still governs the curriculum and aims of British secondary schools. Nor, indeed, would there be much to regret in this if boys got what they were supposed to get, and if the modern "Public School" were as broad and vivifying in its teaching as the earliest schools of the Renaissance both north and south of the Alps. Save in a few cases, the European schoolboy is as a matter of fact not humanized by Latin and Greek. And I hold that it is not, under modern conditions, possible to humanize him on so narrow a basis without a liberal use of translations, familiarity with vernacular literature and an introduction to national and universal history. 


\section{CHAPTER II.}

\section{THE RENAISSANCE AND THE SCHOOL- FIRST PERIOD (I320-I450).}

ThE thought of the Middle Ages, penetrated and sustained (from A.D. I050 at least) by the philosophy of Aristotle ${ }^{1}$, may be said to have summed itself up in the organizing intellect of St Thomas Aquinas, who died r 274. St Thomas was an Italian, and it is in Italy also that we find the earliest intellectual movements which are associated with the revival of letters. In Italy it began, in so far as it was not an outburst of native genius in the vernacular tongue, with a resuscitation of the country's own ancient literature.

I have already said that it is incorrect to say that the new awakening of the mind of Europe to poetry and the arts was determined by the renewed interest in Virgil and Cicero and the subsequent influence of Greek writers. Europe had, in fact, long before begun to seek original expression for its own view of human life. The Provençal poetry, the Northern sagas, the Nibelungenlied, the poetry of the Anglo-Saxons, the mediaeval romances efflorescing in Amadis of Gaul, were the beginnings of a literature which owed nothing to a knowledge of the ancients; and it would be a curious speculation 
what modern literature would have been had it developed on its own independent lines. The rediscovery of the literary achievements of Rome and Greece accordingly, while they gave a powerful impulse to modern thought and linguistic expression, did not create it. And they gave more than impulse. They presented modern Europe, still struggling with its native forms of speech, with a perfected medium of sentiment and thought-literary art of the highest kind. The natural result was that Latin, which had always remained, though barbarized, the language of the educated, was now considered to be the only worthy vehicle of expression. The revival of pure Latinity was thus identified with the revival of literature itself. It cannot be said that at any time this revival of Latin gave birth, save in the case of Erasmus, to genuine literature in Latin. Even Petrarch only partially succeeded. From first to last the writers of the Renaissance were imitative, and even consciously imitative; and original genius could not find expression for itself through what was essentially a foreign medium. All that Latin even with the help of Greek could give, apart from the substance of thought, was vocables, form, and a standard of excellence. We are not far from the truth in saying that a genuine literature is not possible save as a native growth through the organ of the common speech of a people -the mother-tongue of the writer.

\section{Vittorino da Feltre, I378-1446.}

The typical school of the First Renaissance was that of Vittorino da Feltre, born 1378, died 1446. At Mantua, whither he had gone on the invitation of the lord of Mantua (Gonzaga), he opened a school for his children and such others as might be admitted. As directly connected with the reigning family this school might be called a Palatine school, like that of Charlemagne and the ninth century'.

1 Also the school of Nebuchadnezzar and of the Persian kings. 
The success of the school was due to the genius of Vittorino. Endowed with a large share of common sense, he was able to organize a school on the basis of Humanism which neither exaggerated the claims of the ancients nor broke with the mediaeval Christian ideal. The paganism, which already was infecting the Renaissance, was as far removed from Vittorino's sympathies as from those of the transalpine German Humanists of the second period of the Revival. His educational method was influenced by the ancients so far that a sound body was regarded as the condition of a sound mind. Hence games and bodily exercises, to which he attached great importance. The supreme aim, however, was the penetration of the Christian life with classical culture. But he did not exclude, as did many subsequent schools which called themselves Humanistic, other subjects of instruction. He believed that variety of work promoted greater energy and activity of mind in the pursuit of the dominant studies of the school. Arithmetic, geometry, natural philosophy, natural history and music were all admitted to the curriculum. As regards mere intellectual culture, this was measured by him, as by all Humanists everywhere, by command over language. Ratio showed itself in Oratio. Hence the great attention paid to constant composition in Latin on the model of Cicero. In corporal punishment Vittorino did not believe. He could dispense with it; and, indeed, I doubt if any great educator can be named who has not dispensed with it, save in the very last resort. The moral training of the pupils, extending even to their personal carriage, was, considering the looseness of the time, rigid in its character ; but it was accomplished by personal influence and supervision, not by coercion. Vespasiano says that $\mathrm{Da}$ Feltre's academy was a "sanctuary of manners, deeds, and words." Vittorino's school was thus, in marked contrast to the monastic and cathedral schools, an active, healthy, and happy school, with a clearly defined ethical character.

We cannot read the account given by Mr Woodward and 
Mr Addington Symonds (resting largely on Rosmini's life of $\mathrm{Da}$ Feltre) without seeing that this typical Humanist, both in respect of aim and method, was a close follower of Quintilian ${ }^{1}$. The education given was Roman, not Hellenic, as became an Italian school. Much of Quintilian was known before Poggio discovered a complete MS. in I4I4 at S. Gallen. Doubtless Vittorino had perused the whole.

Vittorino died at the age of sixty-nine in 1446 , - the date at which one may fix the beginning of the second period of the Renaissance. "Wholly dedicated to the cares of teaching," says $\mathrm{Mr}$ Addington Symonds", "more anxious to survive in the good fame of his scholars than to secure the immortality of literature, Vittorino bequeathed no writings to posterity. $\mathrm{He}$ lived to a hale and hearty old age, and when he died in 1446 it was found that the illustrious scholar, after enjoying for so many years the liberality of his princely patron, had not accumulated enough money to pay for his own funeral. Whatever he possessed he spent in charity during his lifetime, trusting to the kindness of his friends to bury him when dead. Few lives of which there is any record in history are so perfectly praiseworthy as Vittorino's: few men have more nobly realized the idea of living for the highest objects of their age; few have succeeded in keeping themselves so wholly unspotted by the vices of the world around them."

The "importance of the position of Vittorino" (says Mr Woodward, p. 9r) "lay partly in his own scholarship and reading but more in the genius which he manifested in reducing the vast body of rediscovered literature to the service of a new education." "The old ideal of knowledge, the growth of centuries, was replaced almost within a generation by a new one which should correspond in some way with a

1 "Roman Education," in The Historical Survey of Pre-Christian Education, Longmans, 1897 .

2 Revizal of Learning, p. 297. 
deeper sense of national continuity and of the breadth of human interests." "The relation of the new hope to the old faith, the balance between literary form and moral content, the conflict between the Greek ideal of the body and the asceticism of the Church-here were some of the graver problems that pressed for attention." And I think that we may say that Vittorino solved these problems for himself and for the modern spirit in a combination of religious and Humanistic teaching well-fitted to produce the cultured gentleman and capable citizen. Hallam (Lit. Hist. 1. pt. I. cap. 2) says, "If Gasparin (of Bergamo) was the best writer of this generation, the most accomplished instructor was Victorin of Feltre, to whom the Marquis of Mantua entrusted the education of his own children. Many of the Italian nobility and some distinguished scholars were brought up under the care of Victorin in that city; and in a very corrupt age he was still more zealous for their moral than their literary improvement. A pleasing account of his method of discipline will be found in Tiraboschi, or more fully in Corniani from a life written by one of Victorin's pupils, - Prendilacqua. 'It could hardly be believed,' says 'Tiraboschi, 'that in an age of such rude manners a model of such perfect education could be found: if all to whom the care of youth is entrusted would make it theirs, what rich fruits they would derive from their labours!' The learning of Victorin was extensive; he possessed a moderate library, and, rigidly demanding a minute exactness from his pupils in their interpretation of ancient authors as well as in their own compositions, laid the foundations of a propriety of style which the next age was to display."

Among the writers on Education in Italy bred under the impulse of the first Revival were:

(1) L. Bruni D'Arezzo who wrote De Studiis et Litteris about 1405 .

(2) Petrus Paulus Vergerius, one of the earliest humanistic 
writers on Education, who was born in 1349 and wrote a treatise, De ingenuis moribus, about 1392 .

(3) Battista Guarino, born in 1434, wrote De Ordine Docendi et Studendi (1459).

(4) Aeneas Sylvius Piccolomini (Pope Pius II., died I464), wrote a treatise, De Liberorum Educatione.

These treatises have been translated by $\mathrm{Mr}$ Woodward in his excellent book, Vittorino da Feltre and other Humanist Educators (1897). They all breathe a common spirit. The materials of education, apart from a grounding in Christian faith and practice, are, whether we look to the making of the man or the citizen, Language and Literature as exemplified in the practice of Vittorino. This was the conviction of the Humanists. The Christian life was to be sustained and adorned by the life of culture, and culture was attainable only through the Roman classics, and to a limited extent the Greek writers. The methods of teaching and discipline advocated were, on the whole, much sounder than any that were prevalent even during the second Revival, and far in advance of the practice of secondary schools down to the present time. The training of the body and gymnastic were not lost sight of, I have said, nor were other subjects than Latin ignored. In brief, the whole educational movement of the First Renaissance and much of the Second was an attempt to restore the best type of RomanoHellenic school as that is presented in Quintilian".

We are not, of course, to suppose that there were many schools modelled on that of Vittorino da Feltre or reaching the perfection conceived by those Italians who wrote on Education. But the general spirit and aim of the Humanists undoubtedly began to leaven much of the instruction and to suggest also a humaner moral discipline.

1 Greek was only beginning to be studied and taught. 


\section{CHAPTER III.}

\section{THE SECOND PERIOD OF THE RENAISSANCE (1450-1600).}

\section{Trotzendorf; Sturm; Neander.}

IT was only in the sphere of Christian doctrinal reform that the first Revival can be said to have been operative north of the Alps. It was identified largely with the names of Wykliffe and Huss, and, we may add, Florentius Radewin (died 1400), the founder of the "Brothers of the Common Life," whose aim was practical Christianity (with a tendency to Mysticism) rather than the cultivation of scholastic theology or religious ritual. The second period of the Revival it is customary to date from 1453, - the Fall of Constantinople. The renewed impulse given by the dispersion of Greek scholars, coinciding as it did with the earliest practical application of the printing art, guaranteed permanence. It was only this second Humanistic revival which fully reached Northern nations. To this period belong the transalpine names of Nicolaus of Cusa (d. I464), at once schoolman, Humanist, and religious reformer in the Catholic sense, Rudolf Agricola (d. I 485), Rabelais, Montaigne, Hegius, Erasmus, Sturm, etc. So early as 1476 we find Alex. Hegius at Deventer teaching the elements of Greek and a classical Latinity in the spirit of Humanism to the boy Erasmus among others. But it was quite the end of the century before this example was much followed. The Cathedral school of 
Münster under Langen and Murmellius was famous in the beginning of the r6th century.

The best results of the Humanistic revival in the school were, however, not fully visible north of the Alps until Trotzendorf, friend of Melanchthon, began his scholastic career in 1516 at Görlitz and afterwards as rector $(1524)$ of the Goldberg school. There were many schools, it is true, throughout Europe in which instruction was given on the lines of Trotzendorf, but none so celebrated as his. The organization of the school, the extent to which the elder boys were employed to assist the master both in the discipline and the teaching, the spirit of friendliness between the master and the elder pupils, all anticipate in a remarkable way what is related of Dr Arnold. His school was called a "second Latium." Latin alone was spoken, and the writing of themes in classical Latinity was one of the chief aims of the grammatical discipline. The authors read were, Cicero, Terence, Plautus, Virgil and Ovid. In addition to this, Greek grammar and selections from Greek authors formed part of the curriculum, while logic and rhetoric (the latter chiefly based on the study of Cicero's Orations, guided doubtless by the De Oratore) were taught. Natural philosophy, music, and arithmetic, as then understood, also received an adequate measure of attention. Religious teaching was a conspicuous feature of the school, no less than literature. From this course of instruction we may infer the character of the school, and of similar schools in their

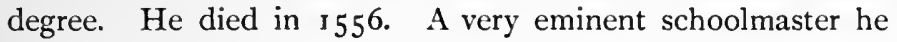
was.

The course of school instruction under the Humanistic influence may also be gathered from the record of John Sturm of Strassburg, where he began his celebrated Gymnasium in ${ }^{1537}$, continuing to superintend it for forty-five years. Sturm, a distinguished scholar and theologian who had taught Greek in Paris, was allied more to the French and Calvinistic than the Lutheran reformers. $\mathrm{He}$ was a vigorous and stern 
master and insisted on the strict obedience of his assistants in the Gymnasium as well as on application to study on the part of the boys. He was a typical disciplinarian. His great idea was education by means of Latin to which Greek was only accessory. The power of speech was with him almost an end in itself. Modern subjects, in so far as they were recognized in the school, were subordinate to the Iatinizing of them. He desired that Latin should meet all the requirements of modern life, and it is not an exaggeration to say that educated Europe would now be speaking and writing in Latin alone, if Sturm had had his way ${ }^{1}$. His strong points as a schoolmaster were the accuracy of work he demanded from each class and his power of organization. There were nine classes, beginning with boys of seven years of age. Each class had its master and each master had in his hand an epistle from the Rector which constituted his marching orders, so to speak. The Strassburg Gymnasium was in fact the model of the Jesuit schools and of all the secondary schools of Europe, much more than the more enlightened Lutheran and Italian schools.

Sturm wrote extensively on the subject of Education.

Michael Neander, again, pupil of Melanchthon, and rector of the Cloister school at Ilfeld in the Hartz, was born in 1525 , and died in $x$ 595. His conceptions of education were large and comprehensive. He had, I think, a more living mind than any other Northern schoolmaster. He even asked himself why he should teach Iatin and Greek at all-a daring, even audacious question in the full tide of Humanism. This openness of mind was, I say, of the essence of Humanism, though already many of the leading Humanists had foreclosed all such questions. Ciceronian Latin had become a fetich, as Erasmus saw. It was not possible for more than one generation of grown men to live solely by imitation. I do not say that Neander, or even 
Melanchthon, deliberately recognized this. They were too much involved in the movement. The question, indeed, could not arise with them; for the duty of all men, then and there, was to connect the life of the modern world with the preChristian. And yet, where the true Hellenic spirit showed itself it could not but be a living and progressive spirit.

Neander showed by his teaching and his curriculum that he possessed the true Hellenic spirit in fuller measure than most. History, geography, science, music,--all entered into his school in addition to the traditionary (but reformed) grammar, rhetoric, and dialectic. He had to make books to supply his wants, where Melanchthon had not already anticipated him. A handbook of natural philosophy and a Compendium Chronicorum (a kind of universal history) and a geography entitled Orbis Terrae Divisio came from his pen. Up to the sixteenth year Latin and Greek were the chief subjects studied; but there was a wide course of reading-so wide indeed that much of it must have been cursive. In the sixteenth year Hebrew was begun, and in the seventeenth and eighteenth the elements and chief precepta of logic and rhetoric; and thereafter physics, geography, and history. If we compare this curriculum with that of the seventeenth and eighteenth centuries, we become alive to the barrenness of even our best schools, after the ardour of young Humanism had cooled. The realism, which is also the reality, of Humanism was, in truth, nobly illustrated at Ilfeld; for there, under Neander, are found the direct contact of the young mind with a wide range of literature, with rhetoric, dialectic, history, and also with the world of nature.

We are not to imagine, however, that there were many schools even in the earlier decades of the 16th century like those of Murmellius, Trotzendorf, Neander, and Sturm; but there were not a few working on the same lines: and in England, after the reforms of Colet (friend of Erasmus and More) in the foundation of St Paul's, the stream of literary 
Humanism flowed through many schools during the 16th century -Stratford-on-Avon, among others, which Shakespeare attended. Elyot and Ascham (1515-1568) were along with Mulcaster its literary prophets.

In the institutions of the men whom I have named we find the best types of the Humanistic school. There was in all of them, as in the earlier Italian school of Da Feltre, a combination of religious with Humanistic aims. The classical fervour of Italy and the religious earnestness of the North met in the educational leaders; and many other teachers throughout Germany, France, and the Low Countries, though less personally distinguished, carried the same combined influences into the daily work of instruction. Nor did these combined aims ever after wholly cease to characterize the secondary schools of Europe. The general curriculum was, however, soon narrowed and the methods degenerated.

The narrowing of the educational aim and the return to mere verbalism was, in truth, not long of coming. If it be the essence of Humanism in its larger meaning that it was an opening of men's eyes afresh to nature and life, the exhaustion of the new movement can be easily understood. For it is given to few men, and those chiefly of poetic temperament, to keep their eyes open for long. There is an instinctive craving for dogma and form; for without these there is no intellectual repose. Each man's philosophy of life is fixed at the point where he grows tired of thinking, it has been said. Even the educated man begins to build his own prison-house very early. Especially must this be the case with teachers, simply because they have to teach; and for this a schoolroom creed of some sort is necessary. They gladly accept what is offered them in the name of authority and tradition, and it is the letter of the doctrine, not the spirit, that governs. They imitate what they have seen done, or apply the technique of a new doctrine which they have once accepted as if it were a revelation. Some schoolmasters will resent this estimate; but the fact is, it is 
only those who recognize the truth of what I say as to the tendency of the pedagogic mind who do think, and keep themselves fresh and open. The intellectual effort and the moral courage required to organize, and the personal enthusiasm required to maintain, the inner life of the Humanistic school of the $15^{\text {th }}$ and 16 th centuries must have been the endowment of few.

The second period of the Renaissance saw the philological and textual movement in full activity, and was distinguished by the names, among others, of the younger Scaliger and Casaubon, and on the religious side by the formulation of Protestant - dogma. The schools unfortunately felt the movement at once, because of the tendency of all teaching to content itself with form and formula and precept. There was no agency for maintaining a scholastic aim and method; the scholastic profession in short was not a profession: it took the colour of the time. It had no independent vitality and no philosophic basis.

But every great movement, even when it is spent, leaves some gain for the world. When we ask ourselves what the I 6th century did for the secondary schools of Europe, we have only to compare the work of the old cathedral and monastery schools with those of the 16 th and 17 th centuries. The classical authors of Greece and Rome were now firmly established as instruments of instruction. It is true that the spirit of Vittorino da Feltre, of Neander and Sturm and Ascham was lost in the 17 th century; but classical books remained, and could not be taken away. Grammar, though then (and now) badly taught, was simplified, because the text-books had been simplified. These were two solid facts which survived and defied the dullest of teachers.

But it appears to me that this was all. The glimmerings of method and the ethical fervour born of the alliance of Humanism with the reformed Christianity had disappeared, and grammar and flagellation, twin brothers, had reasserted themselves- 
indeed from many schools they had never disappeared. Many causes contributed to this: the school cannot be permanently in advance of the time, and every organ of progressive civilization must wait for peace among the nations.

Meanwhile the great scheme of the evangelical Humanists which contemplated a vernacular education for all had received practical effect in many towns; but as a universal scheme it had to wait (except in Scotland, and, later, in Saxony) on political enfranchisement for its full recognition; and this was a business of about 300 years. The extension, however, of primary vernacular religious schools, which had existed in towns . before the Reformation, had received a powerful impulse, and continued to advance wherever the reformed religion was honestly held as a religion of personal conviction and soulexperience. The central position of the Reformers was that between man and God in Christ the personal relation was immediate. No external authority could relieve a man of his duty to work out his onen salvation. For this, knowledge of the truth assimilated by himself was essential, and this, again, was impossible without instruction. Popular education was thus a logical necessity of the position. 


\section{CHAPTER IV.}

\section{UNIVERSITIES.}

IN the Universities the permanent gain to the Humanists was chiefly the introduction of Latin literature, of Greek, a little mathematics, and the genuine Aristotle (though still taught chiefly through a Latin medium), aided by scholastic text-books and bald epitomes. The study of Civil Law had now also more reference to the spirit and life of antiquity, and Medicine began to be more scientific in its ground-work. These higher institutions were however essentially conservative and responded very slowly and unwillingly to the claims of Humanism and of the modern spirit generally.

It has to be remembered that universities were for long placed in a difficult position. They were scholae publicae to which all might go, fit or unfit; and so long as the secondary schools were few in number they had themselves to discharge the function of secondary schools, as they still do at Oxford and Cambridge in the case of all who are unable to pass the previous examination on entrance ${ }^{1}$, and also in the case of the ordinary pass-man. The necessity thus imposed on universities, and which led to their being attended by boys of 13 or 14 , had in mediaeval times been fully accepted, especially at Paris. The result must have been a low standard

1 In the Scottish Universities all have to pass a preliminary examination on entrance. 
of general attainment, except for a select few. Then, the practice of giving school instruction at the universities reacted everywhere throughout Europe to prevent the erection of secondary schools. But the general conception of a university as a school of the higher faculties, law, medicine, theology, and of philosophy (which also was practically a higher faculty) was never quite lost sight of. In Italy during the $5^{\text {th }}$ and 16 th centuries Professors of Latin and Greek literature gathered round them at University and Court centres all who desired culture as opposed to professional instruction, but the universities themselves were not re-organized on a Humanistic basis. The lecturers were in truth constantly moving from place to place like the Greek Rhetoricians in Roman imperial times.

Prior to the i6th century the higher university intellect occupied itself in the department of Arts mainly with logic and metaphysics, as interpreted by the schoolmen in unclassical Latin, and too often based on a partially understood Aristotle. But in the midst of all this they were trying to read for themselves the riddle of life and thought, and they were accomplishing great things, when we consider the conditions under which they worked and the complex dogmatism which they had to rationalize. "Scarcely thirty years ago," says Erasmus ( 1516 ) in a letter to a friend (quoted in Seebohm's Oxford Reformers, p. 399), "nothing was taught at Cambridge but the paria logicalia of Alexander, antiquated exercises from Aristotle, and the 'Quaestiones' of Scotus. In process of time improved studies were added, viz., mathematics, a new, or at all events a renovated Aristotle, and a knowledge of Greek letters." After the $5^{5}$ th century, though scholastic logic and disputations still occupied the field, yet the ultimate reference was now to a better understood authority.

Luther desired to see the curriculum relieved from the Aristotelian metaphysics, ethics, and physics, as taught from text-books, and confined to the logic, rhetoric, and poetics in the original, or studied in epitomes of the original. Cicero's 
rhetoric also he advocated, but without cumbrous commentaries. These philosophic studies, with the addition of Latin, Greek and Hebrew and their literatures, would have constituted Luther's scheme of university reform; and substantially also Melanchthon's. And this with the introduction of a better mathematics was in truth the general line which reform took where it was welcomed. At best, however, it was only initiated.

In short, even after the 16 th century, the Aristotelian encyclopaedia (metaphysics, logic, ethics, poetics, politics, physics) was the ideal curriculum; but now more genuinely Aristotelian than formerly, and not so thickly overlaid with commentary. The mass of students, however, could never get beyond their text-books, and these were still highly scholastic in their form. Thus the complaints of men like Bacon (b. I 56I), and subsequently Milton (b. 1608 ), re-echoed by all educational reformers, were fully justified. In truth, the resettlement of the Faith of Europe, and the great political issues everywhere at stake, added to the natural conservatism of universities, and the inadequate preparation of those coming to them from secondary schools retarded the full growth of modern ideas in the higher education. And yet the planting of mathematics and Greek in Academic Halls and the study of the ancient literatures, by the few at least, were permanent gains. The universities, however, like the rest of the world, had to wait for Bacon and Descartes and Newton, before they could begin to throw off their mediaevalism; and they, doubtless, owed it to the growth of modern literatures that the true purpose of studying the ancient classics was kept alive by being understood.

George Buchanan, the Scottish Humanist, who had taught in the Humanistic College (secondary school) of Bordeaux when Montaigne was a pupil there, and was familiar with the work of the University of Paris, drew up a scheme for the reform of the University of St Andrews, which was printed in 1570 . This is to my mind a very interesting document, 
as being a product of the Humanistic revival, and a record of the university scheme of the Humanists ${ }^{1}$. It is well worthy of our attention as showing the then curriculum of a good university, and I shall give the substance of it. In what we should call the secondary school, but what Buchanan calls (as being part of the university) the "College of Humanity," the course was to extend over six years. From the first, all were required to speak Latin and write a Latin theme daily. Their first reading-book was to be Terence, and thereafter Cicero, Ovid, Virgil and Horace. In the fourth year they were to begin Greek, and in their fifth and sixth, read Homer and Hesiod. The boys were then to be admitted to the "College of Philosophy"-the university proper-and after two years' study they were eligible for the degree of bachelor, the subjects of examination being dialectic, logic and morals. The next year and a half was devoted to natural philosophy, mathematics and metaphysics, after which they received their licencia (equivalent to M.A.). Those intended for the Church then proceeded to the "College of Divinity," where they studied Hebrew, law and theology, expounding passages of Scripture and holding disputations. This scheme of Buchanan's has close affinities to the organization of the Jesuit 'colleges' and academies, the full organization of which was brought into operation about the same time.

In estimating the work of the universities, we must bear in mind that the want of books determined largely the method of teaching. The difficulties by which the diffusion of learning was beset before the invention of printing, may be gathered from the historians of the period, and are well summed up in the following quotation from Mr J. A. Symonds' Renaissance in Italy.

"Very few of the students whom the master saw before him possessed more than meagre portions of the text of Virgil or of Cicero; they had no notes, grammars, lexicons,

1 Hume Brown's vernacular writings of Buchanan (Scots Texts Society). 
or dictionaries of antiquities and mythology to help them. It was therefore necessary for the lecturer to dictate quotations, to repeat parallel passages at full length, to explain geographical and historical allusions, to analyse the structure of sentences in detail, to provide copious illustrations of grammatical usage, to trace the stages by which a word acquired its meaning in a special context, to command a full vocabulary of synonyms, to give rules for orthography and to have the whole Pantheon at his fingers' ends. In addition to this, he was expected to comment upon the meaning of his author, to interpret his philosophy, to point out the beauties of his style, to introduce appropriate moral disquisition on his doctrine, to sketch his biography, and to give some account of his. relation to the history of his country and to his predecessors in the field of letters.

"In short, the professor of rhetoric had to be a grammarian, a philologer, an historian, a stylist and a sage in one. He was obliged to pretend at least to an encyclopaedic knowledge of the classics, and to retain whole volumes in his memory. All these requirements, which seem to have been satisfied by such men as Filelfo and Poliziano, made the Professor of Eloquence -for so the varied subject-matter of Humanism was often called-a very different business from that which occupies a lecturer of the present century. Scores of students, old and young, with nothing but pen and paper on the desks before them, sat patiently recording what the lecturer said. At the end of his discourses on the Georgics or the Verrines, each of them carried away a compendious volume, containing a transcript of the author's text, together with a miscellaneous mass of notes, critical, explanatory, ethical, aesthetical, historical, and biographical. In other words, a book had been dictated, and as many scores of copies as there were attentive pupils had been made. The language used was Latin. No dialect of Italian could have been intelligible to the students of different nationalities who crowded the lecture-rooms. The 
elementary education in grammar requisite for following a professorial course of lectures had been previously provided by the teachers of the Latin schools which depended for maintenance partly on the State and partly on private enterprise."

Even after the invention of printing, books were scarce and dear and had often to be dispensed with. Hallam (Literature of Europe, chap. IV. $\$ 2,3$ I) says: "The process of learning without books was tedious and difficult, but not impracticable for the diligent. The teacher provided himself with a lexicon which was in common use among his pupils and with one of the grammars [he is referring to the teaching of Greek] published on the Continent, from which he gave oral lectures, and portions of which were transcribed by each student. The books read in the lecture-room were probably copied out in the same manner, the abbreviations giving some facility to a cursive hand; and thus the deficiency of impressions was in some degree supplied, just as before the invention of printing. The labour of acquiring knowledge strengthened, as it always does, the memory; it excited an industry which surmounted every obstacle, and yielded to no fatigue; and we may thus account for that copiousness of verbal learning which sometimes astonishes us in the scholars of the 16 th century, and in which they seem to surpass the more exact philologers of later ages.". Unquestionably learning without books had its advantages, but without the cheapening of the art of printing neither learning nor education could ever have been wide-spread.

I have endeavoured very briefly to sum up the gains of the Revival, in so far as it was educational, after it had hardened down into formula and routine. It must be admitted that, even in its narrowest conception, the curriculum of study

${ }^{1}$ In connexion with this, see an interesting passage in Plato's Phaedrus (Jowett's translation, I. p. 63). 
afforded materials, both in the school and the university, whereby a true education might be given by capable men to competent students-especially after the invention of printing. But materials do not themselves suffice: there can be no education where there is no life, no vital intercourse of mind with mind in pursuit of some ideal aim, whether that be style, science, philosophy, Protestant dogma, or Catholic doctrine. The fire burns out, and all that has not gone off in smoke is ashes, and with these generations of youth must content themselves, except where they are re-lighted here and there by the rare genius of an eminent teacher. It cannot be expected that the average schoolmaster or professor should rise above the spirit and methods of the age in which he lives. Great scholars, jurists and theologians, were notwithstanding produced, while the mass of students had now gained access to classical literature and the elements of mathematics. But in the secondary school, and for the ordinary boy, as for the ordinary teacher, life was almost as dreary as ever. Grammar was the despot and rotememory the slave. Verbalism had again reasserted itself, though now, it is true, with higher aims. The attempt to introduce real studies, even history and geography, broke down. In fact, how could it be otherwise? Who, or what agency was there to organize the spirit of the Revival in the school domain and sustain the teacher's ambition to the level which it had reached in a few enthusiastic and original minds?

After the preceding brief survey, the characteristics of the Revival in education will best be studied, I think, in the writings of representative men whom I proceed to speak of. 


\section{CHAPTER V. \\ "THE GOVERNOUR," \\ by Sir Thomas Elyot; d. 1546.}

The Governour, by Sir Thomas Elyot, was unknown save to the learned few until it was edited and reprinted by Mr Croft in I880. The writer was a lawyer, and after holding a legal office for some time he was appointed by Wolsey Clerk of the Council of King Henry VIII. in 1523 . He died in 1546. The Governour was printed 1530-31. The Institutio Principis Christiani of Erasmus is referred to by him, and he is indebted also to other writers (among whom I would include Plutarch).

I think Elyot's book of historical importance for two reasons : first because it seems to have been the first treatise in English written in the spirit of the earlier Italian Humanists, and secondly because it must have exercised influence on the mind of Roger Ascham. It would not serve much purpose to expound the whole of The Governour. I can give the reader a fair acquaintance with its spirit and aims by stringing together its leading precepts, and so letting Elyot speak for himself. Colet, I may mention, died only 10 or 12 years before the publication of Elyot's book, but it was only incidentally that he wrote on education, although historically he was an important figure as founder of the Humanistic School of St Paul's. Accordingly Elyot's work may be accepted as the first full exposition of the Humanistic point of view, not only in English but also in England. 


\section{Early Training.}

"Moreover to the nurse should be appointed another woman of approved virtue, discretion, and gravity, who shall not suffer, in the child's presence, to be shown any act or tache (quality) dishonest or any wanton or unclean word to be spoken: and for that cause all. men, except physicians only, should be excluded and kept out of the nursery. Perchance some will scorn me for that I am so serious, saying that there is no such damage to be feared in an infant, who for tenderness of years hath not the understanding to discern good from evil. And yet no man will deny, but in that innocency he will discern milk from butter, and bread from pap, and ere he can speak he will with his hand or countenance signify which he desireth. And I verily do suppose that in the brains and hearts of children, which be members spiritual, whiles they be tender, and the little slips of reason begin in them to burgeon, there may happen by evil custom some pestiferous dew of vice to pierce the said members, and infect and corrupt the soft and tender buds, whereby the fruit may grow wild, and some time contain in it fervent and mortal poison, to the utter destruction of a realm.

"And we have in daily experience that little infants essayeth to follow, not only the words, but also the facts and gesture, of them that be provect (advanced) in years. For we daily hear, to our great heaviness, children swear great oaths and speak lascivious and unclean words, by the example of other whom they hear, whereat the lewd parents do rejoice, soon after, or in this world, or elsewhere, to their great pain and torment. Contrarywise, we behold some children kneeling in their games before images, and holding up their little white hands, do move their pretty mouths as they were praying: other going and singing as it were in procession: whereby they do express their disposition to the imitation of those things, be they good or evil, which they usually do see or hear. Wherefore not only princes, 
but also all other children, from their nurses' paps, are to be kept diligently from the hearing or seeing of any vice or evil tache. And incontinent as soon as they can speak, it behoveth, with most pleasant allurings, to instil in them sweet manners and virtuous custom. Also to provide for them such companions and playfellows which shall not do in his presence any reproachable act or speak any unclean word or oath, nor to advance him with flattery, remembering his nobility, or any other like thing wherein he might glory: unless it be to persuade him to virtue, or to withdraw him from vice, in the remembering to him the danger of his evil example."

\section{Beginnings of Latin.}

"But there can be nothing more convenient than by little and little to train and exercise them in speaking of Latin: informing them to know first the names in Latin of all things that cometh in sight, and to name all the parts of their bodies: and giving them somewhat that they covet or desire, in most gentle manner to teach them to ask it again in Latin. And if by this means they may be induced to understand and speak Latin; it shall afterwards be less grief to them, in a manner, to learn anything, where they understand the language wherein it is written. And, as touching grammar, there is at this day better introductions, and more facile, than ever before were made, concerning as well Greek as Latin, if they be wisely chosen.

"And in this wise may they be instructed, without any violence or enforcing: using the more part of the time, until they come to the age of seven years, in such dissports as do appertain to children, wherein is no resemblance or similitude of vice."

\section{Variety of occupation.}

"The discretion of a tutor consisteth in temperance: that is to say, that he suffer not the child to be fatigued with con- 
tinual study or learning, wherewith the delicate and tender wit may be dulled or oppressed : but that there may be therewith interlaced and mixed some pleasant learning and exercise, as playing on instruments of music."

Latin not to be seriously begun till the child knowes his own tongue. Qualification of teacher. Discipline.

"After that the child hath been pleasantly trained, and induced to know the parts of speech, and can separate one of them from another, in his own language, it shall then be time that his tutor or governor do make diligent search for such a master as is excellently learned both in Greek and Latin, and therewithal is of sober and virtuous disposition, specially chaste of living, and of much affability and patience: lest by any unclean example the tender mind of the child may be infected, hard afterwards to be recovered. For the natures of children be not so much or soon advanced by things well done or spoken, as they be hindered and corrupted by that which in acts or words is wantonly expressed. Also by a cruel and irous master the wits of children be dulled; and that thing for the which children be oftentimes beaten is to them ever after fastidious: whereof we need no better author for witness than daily experience. Wherefore the most necessary things to be observed by a master in his disciples or scholars (as Lycon, the noble grammarian, said) is shamefastness and praise. By shamefastness, as it were with a bridle, they rule as well their deeds as their appetites. And desire of praise addeth a sharp spur to their disposition toward learning and virtue. According thereunto Quintilian, instructing an orator, desireth such a child to be given unto him, whom commendation fervently stirreth, glory provoketh, and being vanquished weepeth. That child (saith he) is to be fed with ambition, him a little chiding sore biteth, in him no part of sloth is to be feared. And if nature disposeth not the child's 
wit to receive learning, but rather otherwise, it is to be applied with more diligence and also policy, as choosing some book, whereof the argument or matter approacheth most nigh to the child's inclination or fantasy, so that it be not extremely vicious, and therewith by little and little, as it were with a pleasant sauce, provoke him to have a good appetite to study."

After seven years of age the boy should learn Greek before Latin, meanwhile practising Latin colloquially with his fellows and masters. If this be not done, then at least the serious study of both languages should be begun at the same time.

Grammar not to be too prolonged. Authors to be read as soon as possible. Method: Committing to memory.

"Grammar being but an introduction to the understanding of authors, if it be made too long or exquisite to the learner, it in a manner mortifieth his courage: And by that time he cometh to the most sweet and pleasant reading of old authors, the sparks of fervent desire of learning is extinct with the burden of grammar, like as a little fire is soon quenched with a great heap of small sticks: so that it can never come to the principal logs where it should long burn in a great pleasant fire.

"Now to follow my purpose: after a few and quick rules of grammar, immediately, or interlacing it therewith, would be read to the child Esop's Fables in Greek : in which argument children much do delight. And surely it is a much pleasant lesson and also profitable, as well for that it is elegant and brief (and notwithstanding it hath much variety in words, and therewith much helpeth to the understanding of Greek), as also in those fables is included much moral and politic wisdom. Wherefore, in the teaching of them, the master diligently must gather together those fables which may be most accommodate to the advancement of some virtue, whereto he perceiveth the child inclined: or to the rebuke of some vice, whereto he 
findeth his nature disposed. And therein the master ought to exercise his wit, as well to make the child plainly to understand the fable, as also declaring the signification thereof compendiously and to the purpose, foreseen alway, that, as well this lesson, as all other authors which the child shall learn, either Greek or Latin, verse or prose, be perfectly had without the book: whereby he shall not only attain plenty of the tongues called Copie (Copia) but also increase and nourish remembrance wonderfully."

Lucian, Aristophanes and Homer are next recommended to Virgil, Ovid and Lucan; considerable portions of which Elyot will have the boy familiar with by the time he is 14 years old. Thereafter Logic (Topics), Rhetoric (Quintilian) and the Orators, Greek and Latin. He strongly urges the teaching of Geography and the study of Maps. Then History as in Livy, Caesar, Sallust, Xenophon. Then after he is I 7 years old the first two books of Aristotle's Ethics, Cicero's De Officiis, and Plato.

\section{Deficiencies of Schoolmasters. The true method of teaching Literature.}

"Lord God, how many good and clean wits of children be now-a-days perished by ignorant schoolmasters. How little substantial doctrine is apprehended by the fewness of good grammarians. Notwithstanding I know that there be some well learned, which have taught, and also do teach, but God knoweth a few, and they with small effect, having thereto no comfort, their aptest and most proper scholars, after they be well instructed in speaking Latin, and understanding some poets, being taken from their school by their parents, and either be brought to the court, and made lackeys or pages, or else are bound apprentices; whereby the worship that the master, above any reward, coveteth to have by the praise of his scholar, is utterly drowned; whereof I have heard school- 
masters, very well learned, of good right complain. But yet (as I said) the fewness of good grammarians is a great impediment of doctrine. (And here I would the readers should mark that I note to be few good grammarians, and not none.) I call not them grammarians, which only can teach or make rules, whereby a child shall only learn to speak congruous Latin, or to make six verses standing in one foot, wherein perchance shall be neither sentence nor eloquence. But I name him a grammarian, by the authority of Quintilian, that speaking Latin elegantly, can expound good authors, expressing the invention and disposition of the matter, their style or form of eloquence, explicating the figures as well of sentences as words, leaving no thing, person, or place, named by the author, undeclared or hidden from his scholars. Wherefore Quintilian saith, it is not enough for him to have read poets, but all kinds of writing must also be sought for ; not for the histories only, but also for the propriety of words, which commonly do receive their authority of noble authors. Moreover without music grammar may not be perfect; for as much as therein must be spoken of metres and harmonies, called rythmi in Greek. Neither if he have not the knowledge of stars, he may understand poets, which in description of times (I omit other things) they treat of the rising and going down of planets. Also he may not be ignorant in philosophy, for many places that be almost in every poet fetched out of the most subtle part of natural questions. These be well nigh the words of Quintilian.

"Then behold how few grammarians after this description be in this realm."

His remarks on the method of teaching literature are beyond all question the best ever written in so far as my knowledge extends.

Elyot then goes on to advocate games, such as tennis, dumb-bells, wrestling, running, swimming, fencing, riding and dancing; above all archery. 
Painting and carving should be taught to boys where there is any natural talent in that way.

Music also is to be taught but not indulged in to excess.

As regards discipline Elyot was much in advance of his time.

Hallam (Literature of Europe, chap. vil. $\S 2,32$ ) says:"Elyot deprecates [as we have seen] 'cruel and irous schoolmasters, by whom the wits of children be dulled, whereof we need no better author to witness than daily experience.' All testimonies concur to this savage ill-treatment of boys in the schools of this period. The fierceness of the Tudor government, the religious intolerance, the polemical brutality, the rigorous justice, when justice it was, of our laws, seem to have engendered a harshness of character, which displayed itself in severity of discipline, when it did not even reach the point of arbitrary or malignant cruelty. Everyone knows the behaviour of Lady Jane Grey's parents ${ }^{1}$ towards their accomplished and admirable child; the slave of their temper in her brief life, the victim of their ambition in death. The story told by Erasmus of Colet is also a little too trite for repetition. The general fact is indubitable, and I think we may ascribe much of the hypocrisy and disingenuousness which became almost national characteristics in this and the first part of the next century to the rigid scheme of domestic discipline so frequently adopted: though I will not say but that we owe some part of the firmness and power of self-command, which were equally manifest in the English character, to the same cause."

Taking Elyot as a whole we find him to be a genuine believer in the power of education and an admirable representative in England of the fine Humanism of Da Feltre, and one of the most charming writers on education that ever wrote.

1 Alluded to by Ascham in his Scholemaster. 


\section{CHAPTER VI.}

RABELAIS: MONK, PHYSICIAN, CURÉ OF MEUDON. I 483 (?)-I 553 .

\section{[Note on Erasmus (page 55).]}

A CONTEMPORARY of Elyot, but a man of a very different type, was Rabelais. In his great satire and burlesque, the Life of the Great Gargantua, we have some remarks on the education of the hero and, afterwards, advice addressed by Gargantua to his son Pantagruel, giving his own views of the education which he wished him to receive from his tutors ${ }^{1}$. Rabelais satirizes word-teaching - the grammar and logic instruction of his time-pointing out, by producing a cultured youth of the name of Eudemon (an extravagant illustration, of course, like everything in Rabelais), how the ends of education might be attained without the absorption of all the lumber of the Schools. He gives prominence to Latin and Greek, as was inevitable, because these languages contained (for the Western European, at least) all learning both of the past and cotemporary world: but he would direct the attention of the pupils to the real instruction which these languages gave as opposed to the technicalities and formalities of Logic, Rhetoric, and Grammar - the trivium of the Middle Ages.

1 Book 1. caps. 14, 15, 21, 22, 24 ; Book 11. caps. 5, 6, 18. 
In these few words I believe I have summed up the chief lessons which Rabelais teaches. His aim, in brief, is the expansion and enrichment of the human mind as opposed to the overloading of it with the subtleties and superfluous details of a formal grammar, and a still more formal scholasticism. This appears from the account he gives of Gargantua's own education, conducted in the age of pedantry.

\section{Gargantua's ozen education.}

"Presently they appointed him a great sophister-doctor, called Master Tubal Holofernes, who taught him his A B C so well that he could say it by heart backwards; and about this he was five years and three months. Then read he to him, Donat (the popular Latin Grammar for the Middle Ages), Le Facet, Theodolet, and Alanus in Parabolis'. About this he was thirteen years six months and two weeks. But you must remark, that in the meantime he did learn to write in Gothic characters, and that he wrote all his books; for the art of printing was not then in use.

"And did ordinarily carry a huge writing-case, weighing about seven thousand quintals, the pen-case whereof was as big and as heavy as the pillar of Enay; and the horn was hanged to it in great iron-chains, it being of the wideness to hold a ton of merchandise.

"After that was read to him, the Book de Modis Significandi, with the Commentaries of Hurtbise, of Fasquin, of Tropditeux, of Gaulhault, of John Calf (Jehan le veau), of Billonio, of Brelinguandus, and a rabble of others; and herein he spent more than eighteen years and eleven months, and was so well versed therein, that to try masteries in school disputes with

1 Notes explanatory of the books used by Gargantua will be found in François Rabelais. Gedlanken ïber Erziehung und Unterricht, by $\mathrm{Dr}$ Arnstadt, Leipzig. (n. d.) 
his own co-disciples he would recite it by heart backwards; and did sometimes prove on his finger-ends to his mother 'Quod de Modis Significandi non erat Scientia.' Then was read to him the Compost [for knowing the age of the moon, etc.] on which he spent sixteen years and two months. And at that very time, which was in the year 1420, his said Preceptor died.

"Afterwards he got an old coughing fellow to teach him, named Master Jobelin Bridé, who read unto him Hugutio, Hebrard's 'Graecism,' the 'Doctrinale' [a metrical Latin grammar], the 'Partes,' the 'Quid est,' the 'Supplementum, Marmotretus, De Moribus in Mensa Servandis,' Seneca 'de quatuor Virtutibus Cardinalibus,' 'Passavantus cum Commento'; and 'Dormi Securè,' for the holidays, and other such like stuff; by reading of which he became as wise as any we have since baked in an oven."

But what was the result of all this? "That he did profit nothing; but, which is worse, grew thereby a fool, a sot, a dolt, and a blockhead." Being introduced to a youth of excellent accomplishments, called Eudemon, who had followed a more modern style of education - intelligence instead of mere technical memory having been cultivated-Grandgousier thereupon resolves to send his son :to Paris, placing him under Ponocrates, the tutor of the charming Eudemon. We have an account of his life there, which was devoted to hard work, bodily and mental. In the midst of much absurdity and grotesque exaggeration we see that athletics, mathematics, medicine, music, and the reading of classic authors, constituted his chief studies. Rabelais points to the importance of method when he represents Ponocrates, the tutor of Eudemon, as studying the character and natural bent of his pupil Gargantua. He also points to the value of manual work; for Gargantua and his companions "did recreate themselves with bottling hay, cleaving and sawing wood, and threshing sheaves of corn in the barn. They also studied the art of painting and carving." 
At a subsequent period Gargantua writes a letter of advice to his own son Pantagruel, in which we find the views of Rabelais further developed. Athletics, music, classical studies, and the study of Nature are all included in his proposed curriculum. Religious instruction is to be from the Bible as opposed to both scholastic theology and ceremonialism. The aim is, like that of Montaigne subsequently, to develope the pupil's onen thought. 'The letter is as follows:-

"But although my deceased father, of happy memory, Grandgousier, had bent his best endeavours to make me profit in all perfection and political knowledge, and that my labour and study was fully correspondent to, yea, went beyond his desire; nevertheless, as thou may'st well understand, the time then was not so proper and fit for learning as it is at present, neither had I plenty of such good masters as thou hast had: for that time was darksome, obscured with clouds of ignorance, and savouring a little of the infelicity and calamity of the Goths, who had, wherever they set footing, destroyed all good literature, which in my age hath by the divine goodness been restored unto its former light and dignity, and that with such amendment and increase of knowledge, that now hardly should I be admitted with the first form of the little Grammar schoolboys : I say, I, who in my school-days was (and that justly) reputed the most learned of that age. Which I do not speak in vain-boasting.

\section{* * * * * * *}

"Now it is that the minds of men are qualified with all manner of discipline, and the old sciences revived, which for many ages were extinct: now it is, that the learned languages are to their pristine purity restored, viz. Greek (without which a man may be ashamed to account himself a scholar), Hebrew, Arabic, Chaldean, and Latin. Printing likewise is now in use, so elegant, and so correct, that better cannot be imagined, although it was found out in my time but by divine inspiration; 
as by a diabolical suggestion, on the other side, was the invention of ordnance. All the world is full of knowing men, of most learned school-masters, and vast libraries; and it appears to me as a truth, that neither in Plato's time, nor Cicero's, nor Papinian's, there was ever such conveniency for studying, as we see at this day there is. Nor must any adventure henceforward to come in public, or represent himself in company, that hath not been pretty well polished in the shop of Minerva. I see robbers, hangmen, free-booters, tapsters, ostlers, and such like, of the very rubbish of the people, more learned now, than the doctors and preachers were in my time.

"What shall I say? The very women and children have aspired to this praise and celestial manna of good learning; yet so it is, that at the age I am now of, I have been constrained to learn the Greek tongue which I contemned not like Cato, but had not the leisure in my younger years to attend the study of it. And I take much delight in the reading of Plutarch's morals, the pleasant dialogues of Plato, the monuments of Pausanias, and the antiquities of Athenaeus, whilst I wait the hour wherein God my Creator shall call me, and command me to depart from this earth and transitory pilgrimage. Wherefore, my son, I admonish thee to employ thy youth to profit as well as thou canst, both in thy studies and in virtue. Thou art at Paris, where the laudable examples of many brave men may stir up thy mind to many gallant actions; and hast likewise for thy tutor the learned Epistemon, who by his lively and vocal documents may instruct thee in the arts and sciences.

"I intend, and will have it so, that thou learn the languages perfectly. First of all, the Greek, as Quintilian will have it; secondly the Latin; and then the Hebrew, for the holy Scripture's sake. And then the Chaldee and Arabic likewise. And that thou frame thy style in Greek, in imitation of Plato; and for the Latin, after Cicero. Let there be no history which thou shalt not have ready in thy memory; and to help thee 
therein, the books of cosmography will be very conducible. Of the liberal arts of geometry, arithmetic, and music, I gave thee some taste when thou wert yet little, and not above five or six years old; proceed further in them and learn the remainder if thou canst. As for astronomy, study all the rules thereof: let pass nevertheless the divining and judicial astrology, and the art of Lullius, as being nothing else but plain cheats and vanities. As for the civil law, of that I would have thee to know the texts by heart, and then to compare them with Philosophy.

"Now in matter of the knowledge of the works of nature, I would have thee to study that exactly; so that there be no sea, river or fountain, of which thou dost not know the fishes; all the fowls of the air; all the several kinds of shrubs and trees, whether in forest or orchard; all the sorts of herbs and flowers that grow upon the ground; all the various metals that are hid within the bowels of the earth; together with all the diversity of precious stones that are to be seen in the orient and south parts of the world; let nothing of all these be hidden from thee. Then fail not most carefully to peruse the books of the great Arabian and Latin physicians: not despising the Talmudists and Cabalists; and by frequent anatomies get thee the perfect knowledge of the microcosm, which is man. And at some hours of the day apply thy mind to the study of the holy Scriptures: first in Greek, the New Testament with the Epistles of the Apostles; and then the Old Testament, in Hebrew. In brief, let me see thee an abyss and bottomless pit of knowledge : for from henceforward, as thou growest great and becomest a man, thou must part from this tranquillity and rest of study; thou must learn chivalry, warfare, and the exercise of the field, the better thereby to defend our house and our friends and to succour and protect them at all their needs against the invasion and assaults of evil-doers.

"Furthermore I will that very shortly thou try how much thou hast profited, which thou canst not better do than by 
maintaining publicly theses and conclusions in all arts, against all persons whatsoever, and by haunting the company of learned men, both at Paris and otherwhere. But because, as the wise man Solomon saith, wisdom entereth not into a malicious mind and that science without conscience is but the ruin of the soul; it behoreth thee to serve, to love, to fear God, and on Him to cast all thy thoughts and all thy hope, and by faith formed in charity, to cleave unto Him so that thou may'st never be separated from Him by thy sins. Suspect the abuses of the world; set not thy heart upon vanity, for this life is transitory; but the word of the Lord endureth for ever. Be serviceable to all thy neighbours, and love them as thyself; reverence thy preceptors; shun the conversation of those whom thou desirest not to resemble, and receive not in vain the graces that God hath bestowed upon thee. And when thou shalt see that thou hast attained all the knowledge that is to be acquired in that part, return unto me, that I may see thee and give thee my blessing before I die. My son, the peace and grace of our Lord be with thee. Amen.

Thy father,

\section{GARGANTUA.}

From UTOPIA,

the I 7 th day of the month of March."

There is in this letter much extravagance, and it is to be presumed that Rabelais did not regard his whole scheme as practicable, while yet holding to its main purport. If we collate this letter with Gargantua's own education in Paris, the opinions of Rabelais on education may be summed up as follows:- He was bitterly opposed to the grammatical and scholastic studies of his time, and had a wholesome dislike of commentators and critics. He accepted to the full the teaching of the Humanistic revival and desired to send the pupil direct to the works of great writers, and away from futile 
rhetorical rules and empty dialectic. In truth, Rabelais, like Montaigne and all educational reformers, felt with Cleanthes, the philosopher, who, looking back on a better time, says "tunc quidem ipsa res exercebatur, nunc autem verba solum." He certainly inculcates the study of languages; but this not for the sake of languages, but merely because in no other way could the treasures of literature be reached. He urges also the study of science, and commends personal contact with nature. In general, he sees the importance of instruction through the senses and advocates a wide range of realistic study.

Attention to the body and to personal habits, and a good bearing, are also important in Rabelais' eyes. He keeps in view a good, useful and becoming life as the practical end of all education.

It seems to me absurd to call Rabelais a 'realist' because he holds these views. His aim is an intellectual and moral one, and for the attainment of this he recommends the humanistic instruments. If he seems to dwell on the importance of a wide and encyclopaedic knowledge of things, it has to be remembered that he was led to exaggerate this aspect of education through his antagonism to grammarians and schoolmen, and their useless burdening and choking both of the intellect and memories of their pupils with the mere dead forms, - grammatical, rhetorical, and logical,_-of true knowledge. He was no more a realist than Montaigne, who was twenty years old when Rabelais died, and who advocated the views of his precursor at greater length, with a more penetrating insight, and in a more genial, gentle, and rational spirit. With Montaigne the end of education was summed up in the word 'philosophy,' by which he meant wisdom and the conduct of life. A similar aim unquestionably runs through Rabelaiş' teaching. 'The real was opposed to the formal throughout. Religion, again, was with him simple, pure, practical: more nearly allied to the Protestant than the Roman Catholic conception 
of the religious life. Both Rabelais and Montaigne alike were, I hold, Humanists, not Realists, although they naturally emphasized the knowledge of things, because (as I have already said) of the time in which they lived and the special evils they had to combat. No one will hesitate to give Rabelais the credit of having recalled attention to the study of Nature and to the poetic enjoyment of it, as elements in the education of a man. But this does not make him a Sense-Realist.

The importance of Physical Training was also first, in modern times, urged by Rabelais, although it had already received practical attention from leading Renaissance schoolmasters. And when the weather will not admit of outdoor athletics, he makes Gargantua give himself to indoor manual occupation. In truth, there is a great deal in Rabelais-brief as his treatment of the subject is.

The large and liberal curriculum contemplated, including gymnastic and military training as well as music, suggests that Milton's Tractate owed not a little to Rabelais, as did also Locke's Thoughts through the mediation of Montaigne.

I would direct your attention to this : the further we extend our study of writers on Education, the more are we struck with the substantial unity of opinion and object among the greatest of them. Rabelais and Montaigne would have subscribed to almost every word of the early Italian Humanists, and these Humanists, again, reproduced Quintilian. All alike have always before them, as the outcome of all sound teaching, a self-active, living mind. "Accendere animos" is the aim. Plutarch reminds us that the soul is not a vessel to fill, but a hearth on which to kindle a fire. And if the intellectual aim is always the same with the best writers, so even still more are they at one on the supreme importance of moral education and the value of gymnastic.

It is with the rise of the Baconian school that a new idea enters. It is, then, chiefly by acquiring that man is to be 
educated. Knowledge takes the place of wisdom, moral precepts of moral training and personal discipline. This is what is commonly meant by Realism. But even with Ratke and Comenius and their numerous followers, the ultimate purpose is the same as with other writers, viz. wisdom and virtue; but they exaggerate the value of mere instruction as insuring these. The contribution to the science of education made by the Baconian school is not so much in the attention they gave to sense-realism as in the department of method. Locke's Thoughts will be found to be a wise mixture of the Baconian views and of Montaigne. In the Conduct of the Understanding, however, the discipline of the intellect is the theme; and that valuable treatise virtually, in my opinion, restores the grammar and dialectic of the Middle Ages, but these based on the vernacular and on the analysis of concrete writings by the pupil, and not to be attained by the study of formal grammars and logics.

\section{Note ON ERasmus; b. 1466, d. 1536.}

Erasmus was the most brilliant man of the second period of the Revival. I have not had time to study all he has said on Education, and I consequently content myself with this note.

The educational programme of this eminent scholar and thinker was that of the Italian Humanists:-Return to the ancients; classical tongues to be studied in the sources, and no longer in barbarous manuals ; rhetorical exercises to be substituted for useless and obscure dialectic; the study of nature to animate and vivify literary studies; the largest possible diffusion of human knowledge without distinction of age or sex ${ }^{1}$. He severely criticised universities as the homes of mediaeval barbarism and obscurantism, and he advocated strongly a milder discipline in all schools, and cheerful and sanitary class-rooms.

There can be little doubt that Ascham was as largely influenced by Erasmus as by Quintilian. It is superfluous to say that school-

1 Buisson's Dictionnaire de Pédagogie. 
masters listened to neither the one nor the other. Even in these days we see that the tendency of the majority of secondary schoolmasters is to look with all the suspicion which ignorance engenders on all serious study of the principles, aims, and methods of the work to which they have devoted their lives. Some have however advanced far enough to write sentimentally and prettily about it. The most important educational works of Erasmus, apart from his Adages and Colloquies, were the following. [In what follows, I quote from Payne's translation of Compayré's History of Pedagogy.]

\section{Eatucational Works of Erasmus.}

In his book, On the Order of Study (De Ratione Studii), he seeks out the rules for instruction in literature, for the study of grammar, for the cultivation of the memory, and for the explication of the Greek and Latin authors. Another treatise, entitled Of the First Liberal Education of Childrin (De Pueris statim ac liberaliter instituendis), is still more important, and covers the whole field of education. Erasmus here studies the character of the child, the question of knowing whether the first years of child-life can be turned to good account, and the measures that are to be taken with early life. He also recommends methods that are attractive, and heartily condemns the barbarous discipline which reigned in the schools of his time.

Erasmus is one of the first educators who comprehended the importance of politeness. In an age still uncouth, when the manners of even the cultivated classes tolerated usages that the most ignorant rustic of to-day would scorn, it was good to call the attention to outward appearances and the social value of politeness. Erasmus knew perfectly well that politeness has a moral side, that it is not a matter of pure convention, but that it proceeds from the inner disposition of a well-ordered soul. So he assigns it an important place in education.

The Instruction of Women was adrocated by Erasmus. The scholars of the Renaissance generally did not exclude women from all participation in the literary treasures that a recovered antiquity had disclosed to themselves. Erasmus admits them to an equal share. 
In the Colloquy of the Abbe and the Educated Woman, Magdala claims for herself the right to learn Latin, "so that she may hold converse each day with so many authors who are so eloquent, so instructive, so wise, and such good counsellors." In the book called Christian Marriage, Erasmus banters young ladies who learn only to make a bow, to hold the hands crossed, to bite their lips when they laugh, to eat and drink as little as possible at table, after having taken ample portions in private. More ambitious for the wife, Erasmus recommends her to pursue the studies which will assist her in educating her own children, and in taking part in the intellectual life of her husband ${ }^{1}$.

1 Ludovicus Vives, a contemporary of Erasmus ( $4492-1540)$, a Spanish writer of great eminence, expressed similar ideas on the education of women. He recommends young women to read Plato and Seneca. 


\section{CHAPTER VII.}

ROGER ASCHAM, THE HUMANIST';

b. 1515 , d. 1568 .

THE leading topic of Ascham's Scholemaster is the classical languages and literatures as instruments of the education of youth. Mulcaster and Brinsley were the first to advocate the teaching of English"

"Roger Ascham," says Thomas Fuller, "was born at Kirkby-weik in this County (Yorkshire); and bred in Saint John's Colledge in Cambridge, under Doctor Medcalfe, that good Governour, who, zehet-stone-like, though dull in himself, by his encouragement, set an edge on most excellent wits in that foundation. Indeed Ascham came to Cambridge just at the dazening of Learning, and staid therein till the bright-day thereof, his own endeavours contributing much light thereunto. $\mathrm{He}$ was Oratour and Greek Professour in the University (places of some sympathy, which have often met in the same person); and in the beginning of the Raign of Queen Mary, within three days, wrote letters to fourty-seven severall Princes, whereof the meanest was a Cardinal. He travailed into Germany, and there contracted familiarity with John Sturmius and other learned men; and,

1 The quotations which follow are from Bennet's quarto edition, $1 ; 6 \mathrm{r}$.

2 There is a great deal of interesting information on the pre-Reformation schools in Furnivall's Education in Early England. 
after his return, was a kind of teacher to the Lady Elizabeth, to whom (after she was Queen) he became her Secretary for her Latine letters.

"In a word, he was an honest man and a good shooter; Archery (whereof he wrote a Book called 'Tokóolidos') being his onely exercise in his youth, which in his old age he exchanged for a worse pastime, neither so healthfull for his body, nor profitable for his purse, I mean Cock-fighting, and thereby (being neither greedy to get, nor carefull to keep money) he much impaired his estate.

" $\mathrm{He}$ had a facile and fluent Latine-style (not like those who, counting obscurity to be elegancy, weed out all the hard words they meet in Authors): witness his 'Epistles,' which some say are the only Latine-ones extant of any Englishman, and if so, the more the pity. What loads have we of Letter's from Forraign Pens, as if no Author were compleat without those necessary appurtenances! whilst surely our English-men write (though not so many) as good as any other Nation. In

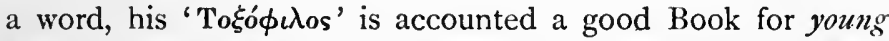
men, his 'School-master' for old men, his 'Epistles' for all men, set out after his death, which happened Anno Domini r 568," in the $53^{\text {rd }}$ year of his age. He was buried in St Sepulchre's, London.

To the above nervous and concise statement I may add that Ascham was privately educated in the family of $\mathrm{Mr}$ Anthony Wingfield, entered St John's College, Cambridge, in 1530 , and took his bachelor's degree in 1534 .

At the University he took with ardour to the new learning and while yet a boy himself instructed others in Greek with a view to his own perfect mastery of the language. Mr Pember, a man of some contemporary eminence, had assured him in a letter that he would gain more knowledge by explaining one of Aesop's Fables to a boy than by hearing one of Homer's poems explained by another.

Being elected to a Fellowship he began to take pupils and 
was soon highly esteemed as a teacher of Greek and became by appointment University Lecturer in that language.

As a writer of Latin he was eminent. All the University letters were written by him in his official capacity of Public Orator. He excelled also in the art of penmanship. $\mathrm{He}$ was appointed to succeed Sir J. Cheke, who probably more than any other one man had promoted the study of Greek literature in Cambridge. He did so not by talking about it, but by reading Greek authors with select pupils, going over a large amount of ground. Being of a delicate constitution and unable to sustain prolonged exertion of mind Ascham took to archery as a recreation; and partly as a defence of his practice he published a book on Archery called "Toxophilus or the School and Partitions of shooting contained in two books written by Roger Ascham i 544. Pleasant for all gentlemen and yeomen of England, for their pastime to read, and profitable for their use to follow both in war and peace."

In writing from Brussels in $\mathbf{1} 553$ to Cecil he defends his practice of archery at the same time that he indicates that he has given it up. "Yet," he says, "I do amiss to dislike shooting too much which hath hitherto been my best friend; and even now looking back to the pleasure which I found in it and perceiving small repentance to follow after it, by Plato's judgment I may think well of it. No, it never called me to go from my book, but it made both wit the lustier and will the readier to run to it again. And perchance going back sometime from learning may serve even as well as it doth at leaping to pass some of those which keep always thus standing at their books; besides that seeking company and experience of men's manners abroad is a fit remedy for the sore wherewith learned men (many say) be much infected withal which is "the best learned not always the wisest.'"

In 1548 Ascham was called to Court to superintend the studies of the Princess Elizabeth.

Being appointed secretary to an English Embassy to 
Germany, he spent nearly three years in various parts of the continent of Europe and wrote his Report and discourse of the affairs in Germany. When at Strassburg he visited the celebrated Rector of the Gymnasium there, John Sturmius, with whom he had maintained a correspondence, but much to his regret found him from home.

It was on his return to England that he served as Latin Secretary at Court under Edward, Philip and Mary, and Queen Elizabeth successively.

The most important of his writings, The Scholemaster, was not published till after his death.

Notwithstanding somewhat straitened circumstances Ascham married on the ist June, 1554. He seems to have been happy in his marriage. In a quaintly expressed letter to Mr W. Pawlett, he says, "God, I thank him, hath given me such an one as the less she seeth I do for her the more loving in all causes she is to me, when I again have rather wished her well than done her good: and therefore the more glad she is to bear my fortune with me the more sorry am I that hitherto she hath found rather a loving than a lucky husband unto her. I did choose her to live withal, not hers to live upon, and if my choice were to choose again I would even do as I did."

Also in a letter to Sturm he says :

"I have such a wife as John Sturm would willingly desire for his Roger Ascham. Her name is Margaret, and I was married on the ist of June, whatever of joyful omen may be in that name and that day."

Ascham, we may see, was not merely a man of great learning but also a man of the world and of affairs, and this adds to the weight of his opinions.

The men who in England were not only most conspicuous, but also most eminent, as representatives of the revival in all strictly educational matters, were Dean Colet, Cheke, and Ascham. The first-named founded St Paul's School, and, 
with the help of Iilly, made it a kind of normal school, as it were, for all England. They both shared the Humanism of their friend Erasmus, but they possessed nore definite Christian conviction and religious purpose than he did. On the other hand, they were not dominated by the theological (as distinct from the Christian) spirit so prevalent among many of the Reformers on the continent of Europe, especially those who lived in the latter half of the sixteenth century. They exhibited, in truth, that example of moderation in opinion and action which, until very recent times at least, has always characterized the reformed Church of England. Ascham lays very little stress on theology; indeed, he seems to me rather to evade the subject. I regard him as a pure Humanist. Colet and his friends belong to the school of Melanchthon; Ascham more to the school of Erasmus, but with a genuine clear, sound and specifically English vein in him.

What is Humanism in education? It is, when largely interpreted, the formation of the mind of youth omnibus artibus quae ad humanitatem pertinent. In its more restricted meaning, as understood in the first revival of letters, it is the formation of the human mind by literature, as opposed to the study of barren words, abstract rules, grammar, rhetorical technicalities, logical sophisticalities, and bald epitomes, all expressed, by master and pupil alike, in barbarous Latinity. It is also the study of style or the beautiful in expression, and this by the perusal of the great writers who express themselves beautifully. At the time of the revival there were (with the single exception of Italian) only two languages known to Europe which, to any large extent at least, exhibited perfection of style, whether in prose or poetry, Greek and Latin. But Latin being the indispensable and universal language of the time, it was Latin literature that had to be chiefly cultivated. Terence, Ovid, Caesar, Virgil, Cicero, constituted the substance of education in the eyes of the Humanists, because they were the best available models of the artistic expression of human thought on human things. Observe that 
I say human thought; for the Humanists, though apparently aiming mainly at education in style, considered that they were thus giving education in 'humane' things-the substance, as well as artistic form, of Literature through which the highest culture of the man was alone possible. Humane letters, the humanities, did not really mean merely style or rhetoric, but the free unencumbered thought of reason on nature and man. It is true that the Humanists emphasized mere style as such, but this arose from the fact that their movement was a reaction against bald and hard grammaticism, barbarous uncouth language, and monkish notions. They truly hated mere words quite as much as the modern senserealists. They were themselves Realists; but their realism was the realism which sought for the things of reason and imagination,- - the product of mind which underlies words. That the truest thought and beauty, or at least fitness, of expression, went together, was in those days simply a fact; and if we do not limit our definition of beauty too narrowly, it is probably still the fact. "Away, then, they said, with grammatical abstractions, with barbarous Latin and logical futilities-that mere 'agitation of wit,' as Bacon calls it, by which the schoolmen lived, and give us literary form, and with literary form true literary substance. This is the proper milk for the growing mind, this is the proper strong meat for the matured!"

In sum, the Humanists went back to Quintilian; and the "good orator" as conceived by the Roman was the aim of the new scholastic method. The correctness of this explanation of the humanistic attitude to the school might be established by citing many writers, were this the place to do so; but, as I am here speaking of Ascham, I shall confine myself to quoting a passage from his chapter on "Imitation," as illustrating and confirming what I have said-a passage all the more worthy of quotation that it exhibits well the trenchancy and amusing vigour of his style. Speaking of the connexion between language and thought, he says- 
"We find always wisdom and eloquence, good matter and good utterance, never, or seldom, asunder. For all such authors as be fullest of good matter and right judgment in doctrine be likewise always most proper in words, most apt in sentence, most plain and pure in uttering the same.

"And contrariwise in those two tongues, all writers, either in religion or any sect of philosophy, whosoever be found fond in judgment of matter be commonly found as rude in uttering their minds. For stoics, anabaptists, and friars, with epicures, libertines, and monks, being most like in learning and life, are no fonder and more pernicious in their opinions than they be rude and harbarous in their writings. They be not wise, therefore, that say, 'What care I for a man's words and utterance, if his matter and reasons be good?' Such men say so, not so much of ignorance as either in some singular pride in thernselves, or some special malice of others, or some private and partial matter, either in religion, or other kind of learning. For good and choice meats be no more requisite for healthy bodies than proper and apt words be for good matters; and also plain and sensible utterance for the best and deepest reasonings; in which two points standeth perfect eloquence, one of the fairest and rarest gifts that God doth give to man.

"Ye know not what hurt ye do to learning that care not for words, but for matter, and so make a divorce between the tongue and the heart. For mark all ages, look upon the whole course of both the Greek and Latin tongues, and ye shall surely find that, when apt and good words began to be neglected, and properties of those two tongues to be confounded, then also began ill deeds to spring; strange matters to oppress good orders; new and fond opinions to strive with old and true doctrine, first in philosophy and after in religion; right judgment of all things to be perverted, and so virtue with learning is contemned, and study left off. Of ill thoughts cometh perverse judgment, of ill deeds springeth lewd talk; which 
four mis-orders, as they mar man's life, so destroy they good learning withal. But behold the goodness of God's providence for learning; all old authors and sects of philosophy which were fondest in opinion and rudest in utterance, as stoics and epicures, first contemned of wise men, and then forgotten of all men, be so consumed by time, as they be now not only out of use, but also out of memory of man. Which thing, I surely think, will shortly chance to the whole doctrine, and all the books of phantastical anabaptists and friars, and of the beastly libertines and monks ${ }^{1}$."

Literary art, or the beautiful in expression, then, was the humanistic aim; and with it, as an inevitable concomitant, the highest and best thought on things human. Even in the teaching of formal rhetoric and logic, which still constituted the higher part of the curriculum of youth, the realism of the Humanists led them to prefer the analysis of rhetorical pieces, and the exhibition of the logical sequence of great literary efforts, to abstract rules of logic or rhetoric. When "Master Cheke" read Greek with Ascham and others in Cambridge, he read author after author. He did not stop to dwell on particles, or to write Greek iambics. He, and men like him, preferred the reality to the mere naming of things, the material to the formal in the abstract sense of the term, though ardent students themselves of perfect form in the æsthetic sense.

Hence, too, the importance the Humanists assigned to the study of the characteristics of the various writers of antiquity. Criticism was revived. Most know the admirable summary of literary history in Quintilian's tenth book. We find in Ascham, in his chapter on "Imitation," to which I have already referred, an equally admirable review, and the student will do well to read both and observe in what respects great writers differed in handling the same subject. An admirable discipline of mind this. Language is so bound up with thought, that in

${ }^{1}$ My quotations are from the large paper quarto ed. of James Bennet, 1761. The best ed. is that of Giles, 1865 . 
teaching language in this critical way, we teach thought and literary appreciation. In criticism, it is not rules of criticism, opinions about authors, to which the student is directed by Ascham, but to the authors themselves. Here, again, the Humanistic Realism shows itself.

Unfortunately, ere long the substance of literature disappeared from the humanistic curriculum: mere style or form, and Ciceronian imitation, became the aim; and then, finally, alas ! grammar, although in a less offensive form than in previous generations and freed from dialectic, reasserted itself. This degeneracy characterized all higher education till quite recently, and still indeed survives.

Ascham wishes it to be distinctly understood that he is not dealing with the question of education in general (as did Elyot, Rabelais and Montaigne) but of school education. He takes the subject up from the day on which a boy enters the grammar school-seven years of age; and the title of his book, The Scholemaster, indicates his self-imposed limitation. And yet, as we shall see, he cannot escape the larger questions.

Ascham's object is to show what a literary or humanistic training truly is, and how it should be set about. It was of course inevitable that he should first deal with the acquisition of the language which was to be the vehicle of the training, viz. Latin; what applied to Latin applied, mutatis mutandis, to Greek. While giving his conclusions as to language-teaching, he always, however, has in his thought the great humanistic purpose of all school instruction. His almost exclusive attention to Latin is explained by the fact that Greek was only beginning to claim attention in the secondary schools, and seems to have been first taught in Colet's school at St Paul's. Few, even in the universities, yet studied Greek, few but ardent ; and these were looked upon with suspicion as innovators and heretics ${ }^{1}$.

I. Method of teaching and learning Latin. After

1 Even elegant Latinity was suspected at Rome. (Pattison's Life of Casaubon.) 
learning the parts of speech-that is to say, what we now call the accidence-and being exercised in the joining together of adjectives and nouns, nouns and verbs, and the relative with its antecedent, the pupil should not be introduced at once, as was the then custom, to Latin composition, because he has not yet the materials, and the result is that wrong words, wrong turns and order in the sentences swarm, and the boy acquires bad habits in Latinity which are never afterwards uprooted. Besides, nothing more discourages children, "dulls their wits, and takes away their will from learning, than the care they have to satisfy their masters in making of Latines."

The proper way to proceed is this: Let the "master read to his pupils the Epistles of Cicero, gathered together and chosen out by Sturmius for the capacity of children.

"First, let him teach the child cheerfully and plainly, the cause and matter of the letter; then let him construe it into English so oft as the child may easily carry away the understanding of it ${ }^{1}$ lastly, parse it over perfectly. 'This done thus, let the child, by-and-by, both construe and parse it over again; so that it may appear the child doubteth in nothing that his master taught him before. After this, the child must take a paper book, and sitting in some place where no man shall prompt him, by himself, let him translate into English his former lesson. Then, showing it to his master, let the master take from him his Latin book, and pausing an hour at the least, then let the child translate his own English into Latin again in another paper book. When the child bringeth it, turned into Latin, the master must compare it with 'Tullie's book, and lay them both together; and where the child doth well, either in choosing or true placing of Tullie's words, let the master praise him and say, 'Here do ye well.' For I assure you, there is no such whetstone to sharpen a good wit, and encourage a will to learning, as is praise" (p. 200).

1 Ratke also advocated this plan. 
"In these few lines I have wrapped up the most tedious part of grammar, and also the ground of almost all the rules that are so busily taught by the master, and so hardly learned by the scholar in all common schools; which after this sort the master shall teach without all error, and the scholar shall learn without great pain, the master being led by so sure a guide, and the scholar being brought into so plain and easy a way. And therefore we do not contemn rules, but we gladly teach rules; and teach them more plainly, sensibly, and orderly than they be commonly taught in common schools. For when the master shall compare Tullie's book with his scholar's translation, let the master at the first lead and teach his scholar to join the rules of his grammar-book with the examples of his present lesson, until the scholar, by himself, be able to fetch out of his grammar every rule for every example; so as the grammarbook be ever in the scholar's hand, and also used of him as a dictionary for every present use. This is a lively and perfect way of teaching of rules; where the common way, used in common schools, to read the grammar alone by itself is tedious for the master, hard for the scholar, cold and uncomfortable for them both" (p. 20r).

"All this while, by mine advice, the child shall use to speak no Latin; for, as Cicero saith in like matter, with like words, 'Loquendo, male loqui discunt.' And that excellent learned man, G. Budæus, in his Greek commentaries, sore complaineth that, when he began to learn the Latin tongue, use of speaking Latin at the table and elsewhere, unadvisedly, did bring him to such an evil choice of words, to such a crooked framing of sentences, that no one thing did hurt or hinder him more, all the days of his life afterwards, both for readiness in speaking, and also good judgment in writing ${ }^{1}$ " (p. 202).

As you will see, the pupil is to have two paper books, the

${ }^{1}$ Muretus, the celebrated humanistic Ciceronian Latinist, always declined to speak Latin. 
one for translation from Latin into English, the other for retranslation from English into Latin.

When he begins to show some facility in these two exercises, the master will begin to call his attention to those words which, though like, have diverse shades of meaning, to words which are synonymous, to phrases, to idioms, and require him to open a third paper book for the recording of these, the pupil classifying what he records under the proper heads. This should be done first with the Ciceronian Epistles, and then he should be introduced to the simpler orations, such as Pro Archia Poeta, and Pro Lege Manilia etc.; and the continuance of exercises in Cicero "shall work such a right choice of words, so straight a framing of sentences, such a true judgment, both to write skilfully and speak wittily as wise men shall both praise and marvel at."

After the pupil has been for some time exercised as above, then read daily with him the third book of Epistles as selected by Sturmius, the De Amicitia, and De Senectute, and also some comedy of Terence or Plautus. Caesar's Commentaries also should be read, "wherein is seen the unspotted propriety of the Latin tongue"; and the speeches of Livy.

It is not necessary at this stage that the pupil should write translations daily. It is sufficient if he construe orally and be examined in the parsing. But the teacher himself, every second or third day, "should choose some epistle ad Atticum, some notable commonplace out of his orations or some other part of Tullie, by his discretion, which the scholar may not know where to find, and translate it himself into plain, natural English; and then give it to the scholar to translate into Latin again, allowing him good space and time to do it both with diligent heed and good advisement." When the scholar brings up his exercise, bring out the Tullie, and compare the work of the pupil with the original, sentence by sentence, word by word, "commend his good choice and right placing of words; show his faults gently but blame them not over sharply; for of such 
missings gently admonished of, proceed glad and good heedtaking; of good heed-taking springeth chiefly knowledge, which after groweth to perfectness, if this order be diligently used by the scholar and gently handled by the master. For here shall all the hard points of grammar both easily and surely be learned up; which scholars in common schools by making of Latines be groping at with care and fear, and yet in many years they scarce can reach unto them" (p. 264).

"I remember," he says, "when I was young, in the north they went to the grammar school little children; they came from thence great lubbers always learning and little profiting; learning without book everything, understanding within the book little or nothing." By the suggested method the pupils will truly know what is in the book. To construe orally, to write translation, then to retranslate, to parse, and to analyze the passage with a view to mark out all the peculiarities, involves the perusal of the passage a dozen times at the least. Thus we follow Pliny's advice to his friend Fuscus_-"Multum, non multa ${ }^{1} . "$

When the scholar has attained considerable skill in retranslating into Latin, then the teacher should proceed as follows. Let him write some letter as if from him to his father or some friend, " naturally according to the disposition of the child," or some fable or narrative, and let him translate this into Latin, "abiding in some place where no other scholar can prompt him." The teacher will use his discretion in such a way as to choose matter within the compass of the boy's previous reading, and "now," says Ascham, "take heed lest the scholar do not better in some point than yourself, except ye have been diligently exercised in these kinds of translating before."

II. CRiticism of CONTEMPORARY Methods. Ascham now proceeds to consider the ways "appointed by the best learned men for the learning of tongues and increase of eloquence,"

${ }^{1}$ Ratke, Milton, and Jacotot, all advocated the thorough "lessoning" of one book in acquiring a language. 
and to give his judgment on the value of these. And first of these is Translation.

Regarding translation and its importance, all agree, he says, but it brings forth little comparatively, (I) because it is single and not double translation; and (2) because of the lack of the daily use of writing, "which is the only thing that breedeth deep root both in the wit for good understanding, and in the memory for sure keeping of all that is learned." 'Tullie, "De Oratore," commends this way. Plinius Secundus also, in an epistle to his friend Fuscus, recommends this mode of procedure with a view not merely to the acquisition of a language, but of Rhetoric, and of a sound judgment in the selection of arguments and expressions. Ascham maintains that any scholar who will translate in this way Tullie, "De Senectute," and the "Epistle ad Quintum Fratrem,". and the other "Ad Lentulum," the last save one in the first book, "will come to a better knowledge of the Latin tongue than the most part do who spend four or five years in tossing all the rules of grammar in common schools." He tells us that Queen Elizabeth, his pupil, never took grammar in her hand after the first declining of the noun and verb, " but only by this double translating of Demosthenes and Isocrates daily without missing every forenoon, and likewise some part of Tullie every afternoon, for the space of a year or two, had attained to such a perfect understanding in both the tongues and to such a ready utterance of the Latin, and that with such a judgment as they be few in number, in both the universities or elsewhere in England, that be in both tongues comparable with her majesty" (p. 272).

Another argument used by Ascham is that in this exercise the master as well as the pupil is guided to correct expression.

At this stage, instruction in the mere structure of the language may be held to end. What follows belongs to the best means of forming style as distinct from merely grammatical writing in its plainest form. Paraphrasing, meta- 
phrasing, epitome, imitation, declamation, are all considered in their order.

Of Paraphrasing, he says: This was first tried by C. Carbo, and tried for a while by Lucius Crassus, but condemned by him and Cicero. Quintilian, it is true, commends the practice. Pliny, Quintilian's pupil, however, condemned it. He calls it audax contentio. Ascham calls the practice "the turning, chopping and changing the best to worse." The scholar, if he has, as he is presumed to have, a good model, is in fact trying to express in a worse and inferior way what is already expressed beautifully. "The scholar," says Ascham, "shall win nothing by paraphrasis, but only (if we may believe Tullie) to choose worse words, to place them out of order, to fear overmuch the judgment of the master, to mislike overmuch the hardness of learning; and by use to gather up faults which hardly will be left off again" (p. 274). Ascham here enters into the question of the rhetorical benefit, as well as the grammatical, of such exercises. He quotes Sturmius, who counsels all to avoid paraphrasis, unless it be from worse to better.

The only case in which paraphrasis is valuable is, Ascham thinks, in turning Ionic or Doric into the Attic form or style. A good example of this is the translation of Herodotus' story of Candaules and Gyges out of the Ionic into the Attic by

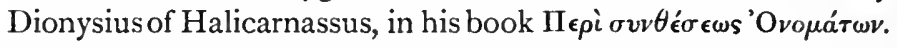
Ascham believes that such exercises would give great power over the Greek tongue, but it is evident that they are beyond the scope of grammar-school teaching, and belong rather to the university.

Metaphrasis is the turning of prose into verse, or vice-versâ. Socrates amused himself in prison by turning Æsop's fables into verse. Quintilian lauds the exercise, but Ascham thinks it of doubtful value save at the university stage (boys went to the university at fifteen or even younger), and then only in very competent hands. He gives examples; but, in truth, they are not truly examples, it seems to me, of deliberate 
metaphrasis, but rather of imitation, which is unquestionably a good exercise. We have an illustration in the comparison of parallel passages in eminent writers, the study of which is, in capable hands, I think, full of the elements of literary and rhetorical culture.

Under the head of Epitome, he remarks that Epitomes are of great utility if made by a student himself for his ozen use; but they are hurtful to teach from.

The rest of the chapter is, in reality, a short treatise on vices of style, and has reference rather to rhetoric than to the work of the schoolroom. There occur in the course of it many wise observations and not a little keen criticism and sarcasm, and it is as a whole most interesting and instructive.

Imitation.- "Imitation is a faculty to express lively and perfectly that example which ye go about to follow."

"All languages both learned and mother-tongues be gotten and gotten only by imitation."

"If ye would speak and write as the best and wisest, ye must be conversant where the best and wisest are."

This chapter is, in truth, a continuance of the treatise on rhetoric begun in the previous chapter. $\mathrm{He}$ dwells on the necessity of comparing the great classical authors one with another, so as to ascertain and mark carefully in what respects they differed in their mode of handling the same subjects. In Ascham's generation, pure style was the mark of true learning, as opposed to the barbarous Latinity and vain disputations of the schoolmen, which were identified with ignorance. There is consequently an exaggeration of the necessity of imitation, which was due to the circumstances of the time and the state of learning. The object of the Humanists was to form style through the study and reproduction of the best models. Every classical student should read this chapter, as it contains many just criticisms on classical authors. A portion of it may be compared with Quintilian's remarks on great writers in his tenth book to which I have already 
referred. I doubt if more sound criticism on the literature of Greece and Rome is to be had, than may be found in the brief analysis contained in the writings of these two men taken together.

Ascham, in his commendation of imitation, has evidently in view the literary translation of a passage in a famous author from the language in which he writes into another, and is influenced by the opinion of Pliny in Epist. vil. 9, where he says, writing to his friend Fuscus, "You ask me what I think should be your method of study in the retirement which you have been for some time enjoying. As useful as anything, as it is frequently recommended, is the practice of translating either your Greek into Latin, or your Latin into Greek. By practising this, you acquire propriety and dignity of expression, an abundant choice of the beauties of style, power in description and in the imitation of the best models, a facility of creating such models for yourself. Besides, what may escape you when you read, cannot escape you when you translate. From this follows a quick appreciation of beauty and sound taste. There is no reason why you should not write about the subjects which you have been already reading, keeping to the same matter and line of argument, as if you were a rival; should then compare it with what you have read, and carefully consider whether the author has been the happier of the two, and wherefore. You may congratulate yourself much if sometimes you have done better, but should be much ashamed if he is always superior. Sometimes you may select even very famous passages, and compete with what you select. The competition is daring enough, but, as it is private, cannot be called impudent '." Such exercises are only, it is clear, for advanced scholars.

III. The IMPoRtance OF KNOWING MORE THAN ONE LANGUAGE. Speaking again of the importance of knowing

1 Translared by Messrs Church and Brodribb in Ancient Classics for English Readers. 
more languages than one, with a view to style, he says (p. 308)-

"Therefore thou, that shootest at perfection in the Latin tongue, think not thyself wiser than Tullie was, in choice of the way that leadeth rightly to the same: think not thy wit better than Tullie's was, as though that may serve thee that was not sufficient for him. For, even as a hawk flieth not high with one wing, even so a man reacheth not to excellency with one tongue.

"I have been a looker-on in the cock-pit of learning these many years; and one cock only have I known, which with one wing, even at this day, doth pass all other, in mine opinion, that ever I saw in any pit in England though they had two wings. Yet nevertheless, to fly well with one wing ${ }^{1}$, to run fast with one leg, be rather rare masteries much to be marvelled at, than sure examples safely to be followed. A bishop, that now liveth, a good man, whose judgment in religion I better like than his opinion in perfectness in other learning, said once unto me, "We have no need now of the Greek tongue, when all things be translated into Latin.' But the good man understood not, that even the best translation is for mere necessity but an evil imped wing to fly withal, or a heavy stump leg of wood to go withal. Such the higher they fly, the sooner they falter and fail: the faster they run, the ofter they stumble and sorer they fall."

IV. School Discipline. In handling this part of method, Ascham speaks with justice, though sometimes with acerbity, of teachers. His remarks being quite fresh, and applicable, to a large extent at least, to the circumstances of our present time, I shall ask your attention to them. Apart from their intrinsic value, the raciness and verve of the language in which they are expressed justify my quoting them.

Discipline was, in Ascham's own view, a very important

1 " Habeas licebit alterum pedem Ladae, Inepte, frustra crure ligneo curres" (Martial, x. 82). 
part of his treatise. In the preface narrating the circumstances which led to his undertaking the book, we see that it was the question of school discipline which led him to take up his pen. Some boys had run away from Eton because of the severities there practised, and this led to a conversation among some men of the time, in the course of which Ascham maintained that "children were sooner allured by love than driven by beating to attain good learning." Others concurred, Sir Robert Sackville citing his own sad experience, which, however, seems to have been a very common one. Ascham's school-method, accordingly, had for its motive a moral purpose. In the course of his remarks he is naturally led, like Quintilian, to make various wise and discriminating remarks on the different characters of boys.

As to the relation between teacher and scholar Ascham wishes that the scholar should never have any hesitation in asking the master questions. The relation should be of so free a kind, that he will not be driven to seek for prompting or to resort to unlawful means of obtaining help'.

"If the child miss," he says, "either in forgetting a word, or in changing a good with a worse, or mis-ordering a sentence, I would not have the master either frown or chide with him, if the child have done his diligence and used no trowandship therein. For I know by good experience that a child shall take more profit of two faults gently warned of, than of four things rightly hit" (p. 20r).

As to discipline generally, Ascham is an advocate for love rather than fear. "I do gladly agree," he says, "with all good schoolmasters to have children brought to good perfectness in learning, to all honesty in manners, to have all faults

1 Another great Humanist, Cardinal Wolsey, in his directions to the master of Ipswich School (1528), says, "Imprimis hoc unum admonendum censuerimus ut neque plagis severioribus neque vultuosis minis aut ulla tyrannidis specie tenera pubes afficiatur; hac, enim, injuria ingenii alacritas aut extingui aut magna ex parte obtundi solet." 
rightly amended, to have every vice severely corrected; but for the order and way that leadeth rightly to these points we somewhat differ" (p. 206). Schoolmasters, he says, rather mar than mend their pupils by their severity. When angry with some other matter altogether, they make their pupils suffer for it. These be foolish schoolmasters, you will say, and there be few of them: foolish they be, but "over many such be found everywhere." "In punishing, too, they quite as often punish nature, as correct faults. Yet some men, wise indeed, but, in this matter, more by severity of nature than any wisdom at all, do laugh at us when we thus wish and reason that young children should rather be allured to learning by gentleness and love, than compelled to learning by beating and fear." "They say our reasons serve only to breed forth talk and pass away time; but we never saw good schoolmasters do so, nor never read of wise men that thought so." He then brings against them the judgment of Plato, who says: "No learning ought to be learned with bondage; for bodily labours wrought by compulsion hurt not the body, but any learning learned by compulsion tarrieth not long in the mind." $\mathrm{He}$ also points out that young men trained by compulsion, when by time they come to their own rule, carry commonly from school with them a perpetual hatred of their master, and a continual contempt for learning. He then contravenes the opinion that children have a natural distaste for learning, and throws the blame on the schoolmaster. $\mathrm{He}$ also advises doubters to read John Sturmius, "De Institutione Principis." At the same time, he countenances beating for moral faults; but not for intellectual shortcomings. "Yea, many times the better nature," he says, "is sore punished: for if one by quickness of wit take his lesson readily, another by hardness of wit taketh it not so speedily, the first is always commended, the other is commonly punished; when a wise schoolmaster should rather discreetly consider the right disposition of both their natures, and not so much weigh what either of them is able 
to do now, as what either of them is likely to do hereafter. For this I know, not only by reading of books in my study, but also by experience of life abroad in the world, that those which be commonly the wisest, the best learned, and best men also, when they be old, were never commonly the quickest of wit when they were young. The causes why, amongst other, which be many, that move me thus to think, be these few which I will reckon. Quick wits be commonly apt to take, unapt to keep; soon hot, and desirous of this and that, as cold, and soon weary of the same again; more quick to enter speedily than able to pierce far; even like over sharp tools, whose edges be very soon turned. Such wits delight themselves in easy and pleasant studies, and never pass forward in high and hard sciences. And therefore the quickest wits commonly may prove the best poets, but not the wisest orators : ready of tongue to speak boldly, not deep of judgment, either for good counsel, or wise writing. Also for manners and life, quick wits commonly be, in desire newfangled, in purpose unconstant, light to promise anything, ready to forget everything, both benefit and injury: and thereby neither fast to friend, nor fearful to foe: inquisitive of every trifle, not secret in greatest affairs ; bold with any person, busy in every natter; soothing such as be present, nipping any that is absent; of nature also always flattering their betters, envying their equals, despising their inferiors ; and, by quickness of wit, very quick and ready to like none so well as themselves" (p. 206).

Ascham afterwards gives the notes of the best wits for learning, following Plato, viz. -

A mind well disposed generally,

Of a good memory,

Loving learning,

Loving labour,

Loving to learn of others,

Disposed to ask questions,

Loving praise.

We may compare with this a parallel passage in Quintilian's 
first book; but Ascham works the whole question out much more fully than Quintilian.

V. Virtue. We now see Roger Ascham's aim in education : it was a humanistic aim in the broadest sense. I have shown you briefly his method of teaching language and forming style, and given you his views of scholastic discipline. In all you see a man of simple and direct outlook, of strong and manly sense, of moral purpose and vigour. Had he no higher purpose than culture in the humanistic sense? Of course he had. All men who have written about education, and who are worth reading, have placed before themselves the ethical outcome of school and its studies as the highest. In the latter part of his treatise (and, indeed, all through) Ascham shows how sensible he was of the prime importance of this aspect of education, and in the whole of the first book of The Scholemaster, the moral result of the discipline which he advocates is constantly present to his mind. "Virtue and learning," these go together as inseparable. He desires that children be brought up in "God's fear" to "honesty of life and perfectness of learning." This training to virtue is, after all, his main interest. In his Toxophilus he says, "If a young tree grow crooked, when it is old a man shall rather break it than straight it." He was too much of a Greek not to have constantly before

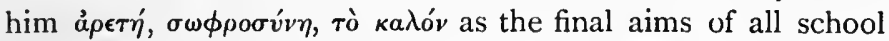
work. "To come down," he says, "from higher matters to my little children, and poor schoolhouse again, I will, God willing, go forward orderly to instruct children and young men both for learning and manners." "I wish," he says, "to have love of learning bred up in children. I wish as much to have young men brought up in good order of living, and in some more severe discipline than commonly they be." The schoolmaster has to see to this, but "always using such discreet moderation as that the schoolhouse should be counted a sanctuary against fear."

But he felt that the most pressing matter was the method and quality of the instruction; as alone insuring milder discipline, and 
he accordingly devotes himself formally to the consideration of these; but the higher aim runs like a thread through the whole treatise. To the attainment of this higher aim a better method and a milder discipline were preconditions, and accordingly he throws his force on them. But learning, he well knew, will not suffice alone; and yet we may be assured that if a youth's mind be brought into contact with the highest literary forms, and through literature with the substance of morality, learning will do much.

"Learning," says Ascham, "teacheth more in one year than experience in twenty; and learning teacheth safely when experience maketh more miserable than wise. He hazardeth sore that waxeth wise by experience. An unhappy master he is that is made cunning by many shipwrecks ${ }^{1}$." And again, "Learning, ye wise fathers, and good bringing up, and not blind and dangerous experience, is the next and readiest way, that must lead your children, first to wisdom, and then to worthiness, if ever ye purpose they shall come there. And to say all in short, though I lack authority to give counsel, yet I lack not good will to wish, that the youth in England, specially gentlemen, and namely nobility, should be by good bringing up so grounded in judgement of learning, so founded in love of honesty, as, when they should be called forth to the execution of great affairs in service of their prince and country, they might be able to use and to order all experiences, were they good, were they bad, and that according to the square, rule, and line of wisdom, learning, and virtue" (p. 238). "Italy and Rome," he elsewhere says, "have been, to the great good of us that now live, the best breeders and bringers-up of the worthiest men, not only for wise speaking but also for welldoing in all civil affairs, that ever was in the world." "Virtue once made that country mistress over all the world; vice now

1 The saying of Erasmus may be applied to those schoolmasters who do not study philosophy and method as well as to young men: "Experience is the common schoolhouse of fools and ill men." 
maketh that country slave to them that before were glad to serve it." If we would avoid such a fate, we must train and discipline the young, so that they may "find pain in doing ill"; and if "to the goodness of nature be joined the wisdom of the teacher, in leading young wits into a right and plain way of learning, surely children kept up in God's fear, and governed by His grace, may most easily be brought well to serve God and their country both by virtue and wisdom" (p. 221 ). "The foundation of youth well set (as Plato doth say), the whole body of the commonwealth shall flourish thereafter."

VI. Gymnastic and Music. A man of Ascham's antique habit of thought was not likely to omit the Greek gymnastic out of his consideration. He urged that young gentlemen should "use and delight in all courtly exercises and gentlemanlike pastimes." The Athenians, by making Apollo and Pallas "patrons of learning to their youth," meant that learning should always be mingled with honest mirth and comely exercises. "All pastimes joined with labour, used in open place and in daylight, containing either some fit exercise for war or some pleasant pastime for peace, be not only comely and decent, but also very necessary for a courtly gentleman to use." But it is in the Toxophilus that we find gymnastic as an element in education most strongly urged. He says there, "I heard a good husband at his book once say, that to omit study some time of the day and some time of the year, made as much for the increase of learning as to let the land lie sometime fallow maketh for the better increase of corn." And he quotes Aristotle as saying, "that as rest is for labour and medicines. for health, so is pastime at times for sad and weighty study." For keen and able minds physical exercise was more necessary than for dull and plodding intelligences: "The best wits to learning" (he says in his Toxophilus) "must needs have much recreation and ceasing from their books, or else they mar themselves, when base and dumpish wits can never be hurt by continual study." 
It was as pastime only that he advocated gymnastic. The Hellenic idea that gymnastic had itself a moral aim did not occur to Ascham. At the same time, he points out that some pastimes not only contribute more to the health of the body than others do, but are more conducive to morality, by being public and demanding labour of body. For Ascham, and indeed the Humanists generally, were practical believers in the old saying of Epicharmus, that God has sold virtue and many other good things to man in return for labour, and that amusement where there was no labour was hurtful to youth.

In his Toxophilus Ascham regrets that not more than one youth in six entering Cambridge can sing. $\mathrm{He}$ also deplores the decline of the practice of teaching the children of England "plain-song and prick-song"." $\mathrm{He}$ evidently attaches a moral value to music-teaching, and on this point quotes Plato and Aristotle with approval. In the Cathedral grammar-schools prior to the Reformation the course of instruction almost always included singing. In fact the schools were often called "Song schools." Ascham complains that only one in six could sing; how many Cambridge freshmen can sing to-day?

Ascham's aim, as we have seen, was the same as that of all the Humanists and we may say of all educational writers worth reading - the promotion of virtue and wisdom. In his Preface he says, "In the bringing up of youth there are three special points-truth of religion, honesty of living, and right order in learning. In which three ways I pray God my poor children may walk." The means whereby the end was to be obtained was literature, and the "criticism of life" which is embodied in literature. Literature furnished the materials with which the human mind was to be fed, as well as the vehicle of discipline. In the acquisition of literature, and in coming into personal contact with great and heroic examples,

1 Music in parts. 
the true moral discipline for youth consisted. The study of language, which specially belongs to boyhood, is the study of literature in its elements, and trains at every step the powers of perception, discrimination, and judgment, while laying the foundation for higher things.

Do not suppose that I have exhausted Ascham : this is a mere introduction to the study of him. Of his method, generally, we may say that it was a sound and sensible one. If followed, it would certainly give the intellectual and moral discipline at which he aimed, and remove those obstacles to learning which make it hateful to boys. He did not deal with the art of education on psychological principles. In his time there was no psychology. But a keen, vigorous, and sane mind like Ascham's could hit very near the mark without the formal machinery of philosophy :-

"He knew what's what, and that's as high As metaphysic wit can fly."

(Butler's Hudibras, pt I, canto I, 1. I 49.)

And what came of it all, so far as the practice of schools is concerned? Nothing. And yet that staunch old Tory, Samuel Johnson (and not alone weak-headed "theorists" who have always been suspected of revolutionary proclivities), says that "it contains, perhaps, the best advice that was ever given for the study of languages." And Mr Quick tells us that Professor J. E. B. Mayor declares that "this book sets forth the only sound method of acquiring a dead language." Had Ascham's own college (St John's, Cambridge) founded a lectureship on education, three hundred years ago, restricted to Quintilian and Ascham, the whole course of English education would have been powerfully influenced.

To return to Ascham himself: his characteristics, as revealed in his writings, appeared in his life. He was a pleasantmannered and a brave man, and called forth the affection as 
well as esteem of his contemporaries. We find no exaggeration in the epigraphic lines of George Buchanan-

\author{
"Aschamum extinctum patriæ, Graiæque Camenæ \\ Et Latice, vera cum pietate, dolent ; \\ Principibus vixit carus, jucundus amicis, \\ Re modica, in mores dicere fama nequit."
}

\title{
SUPPLEMENTARY NOTES.
}

I. Among the educational treatises of note during this century was that of Hieronymus Wolf, "Docendi discendique ratio," published about 1576.

2. The student of Education would do well to read in connexion with the whole period of the Renaissance Guizot's Lectures on Civilization in Europe, and Hallam's Literary History of the Middle Ages, and to consult Symonds' exhaustive work.

3. The two passages on which Ascham confessedly bases his system of "Double Translation" are Cic. de Orat. I. 34, and Plin. Epistol. vil. 9. In the passage from the De Oratore the words are put into the mouth of M. Licinius Crassus, the most illustrious of Roman orators before the time of Cicero. The latter was not only trained by Crassus when a boy (de Oratore, II. I, 2) but appears to have selected him as the mouthpiece of his own views in the dialogue. The passage referred to is as follows :

Cicero de Orat. I. 34. "But in my daily exercises I used, when a youth, to adopt chiefly that method which I knew that Caius Carbo, my adversary, generally practised; which was, that having selected some nervous piece of poetry, or read over such a portion of a speech as I could retain in my memory, I used to declaim upon what $I$ had been reading in other words, chosen with all the judgment that I possessed. But at length I perceived that in that method there was this inconvenience, that Ennius, if I exercised myself on his verses, or Gracchus, if I laid one of his orations before me, had forestalled such words as were peculiarly appropriate to the subject, and such as were the most elegant and altogether the best; so that if I used the same words, it profited nothing: if others, it was even prejudicial to me, as I 
habituated myself to use such words as were less eligible. Afterwards I thought proper, and continued the practice at a rather more advanced age, to translate the orations of the best Greek orators; by fixing upon which I gained this advantage, that while I rendered into Latin what I had read in Greek, I not only used the best words, and yet such as were of common occurrence, but also formed some words by imitation, which would be new to our, countrymen, taking care, however, that they were unobjectionable.'

Watson's Translation (Bohn's series).

4. The letter of Pliny (vil. 9) referred to in the text is addressed to Fuscus, one of his many literary friends, who had been asking him for advice as to his studies. The whole letter is exceedingly interesting.

5. The most important English writers of the period after Ascham were Mulcaster, d. I6II, who wrote Positions (vide Quick's edition) and The Elementarie; and Brinsley, who wrote on the Grammar School.

6. The most important of the men omitted is probably the German Wimpheling, whose book, Guide for the German Youth, was published in 1497, followed by Die Jugend in 1500. The writings of this distinguished educationalist would, I have no doubt, repay a study which I have not time to give to him. The man who wrote (Janssen's History of the German People at the Close of the Middle Ages, p. 8o) "Let cultivation be for the quickening of independent thought" was far removed from the Mediaeval school. 


\section{CHAPTER VIII.}

\section{THE JESUITS.}

Order founded in 1534 .

IN some respects the greatest educational movement generated during the second period of the Renaissance was that of Ignatius of Loyola (born I49I, died 1556), the founder of the Jesuit Order. To this I have already adverted; but it merits a fuller notice, because it was a scheme of university as well as of secondary instruction. This order, founded in 1534 by Ignatius of Loyola and five associates, knew what it wanted; the Protestant Humanists did not. As recognized by Papal Bull in $154^{\circ}$, it was primarily a missionary organization. Adapting themselves to the urgent wants of the time, the members devoted themselves to education and to the cultivation of learning. Primary education certainly received its great impulse from the Reformers, dogma and the "godly upbringing" of the young being the governing aim. We cannot say the same of secondary instruction, although there were many excellent secondary schools of a Protestant character. But the higher education generally was left to the Jesuits to undertake.

It was not the Renaissance as a literary and aesthetic, but as a theological movement, which led to the institution of the 
Jesuit schools. They were bulwarks of the Faith. They adopted as much of Humanism as served their purpose. To say what a Jesuit school was as compared with a cathedral or monastery school is not difficult. Latin formed in the former, as in the latter, the central subject of instruction, but now it was the Latin of classical antiquity. Eloquence in the restricted sense of Latin style was the aim. The main purpose of this system apart from its governing religious idea was to give command of Latin as a medium of communication no less than of personal culture. The service of the Church was the end of all learning. Orators and poets were studied with a view to this. A marked advance on the mediaeval studies was thus a conspicuous feature of the school system, and as Lord Bacon says in The Advancement of Learning "partly in themselves, partly by the emulation and provocation of their example, they quickened and strengthened the state of learning." One hundred Colleges and Houses were established within fifteen years of the foundation of the Order. In 1640 they numbered 372. Prior to the French Revolution there were ninety Colleges (secondary schools, and high schools or "Academies") in France alone. And these secondary schools and universities were far in advance of Protestant and State institutions. If we add the elements of Greek to Latin oratory we say all that there is to be said as to the central subjects of secular instruction. There is no record of any Jesuit school, so far as I know, which approached in its breadth of study or in the organization of school work the Protestant Gymnasium of Sturm at Strassburg, much less the school of Neander or of Trotzendorf - examples however which were not largely followed by Protestants.

How was it then that the Jesuit schools so far excelled the Humanistic secondary schools of the Reformation as wholly to eclipse them and to evoke the approval of Bacon and other Protestant men of eminence? The answer is contained in one word, organization. 
(I) There was a ratio studiorum deliberately laid down and carried out.

(2) There was an organization of the teaching staff so conceived as to attain the objects of the school and suited to a system of carefully graded classes. The work was thorough throughout.

(3) There was a ratio docendi et discendi. A great many sensible rules of method in teaching were adopted and put into practice. All parts of the school were subjected to one idea and to one unquestioned authority. The school worked as an organism.

To these characteristics we must add that the discipline was comparatively mild (always a consequence of good organization). There were unwholesome elements in the discipline, it is truetoo much emulation and a tendency to espionage and its consequent evils; but it was freed from the harshness that characterized other schools. Great attention also was paid to the health and bodily vigour of the pupils. If we add to this that all the schools were everywhere alike as being under one Order, and thus commanded the confidence of parents, we can easily see that success was certain. The Protestant schools had too much individualism about them. Their educational theory was larger, their course of instruction for a time theoretically wider, the spirit that animated them was more that of Humanism and freedom, but against such characteristics, admirable as they are, organization and recognized system will always carry the day.

7 It was, then, not only by their activity in politics and Church work that the Jesuits arrested the tide of Protestantism, but also and chiefly by their schools. They believed in education as moulding the future man, and had a conviction of its power, which even to this day Protestants do not share, spite of all their platform talk. At one time it almost appeared as if the whole secondary and university education of the Continent of Europe would fall into their hands, and had it not been for the 
restriction of their aims by Church requirements, the tendency of their system to crush out spontaneity, the reactionary character of their most advanced teaching, the ultimate issue and crown of which was, mediaeval philosophy and theology, complete success, it seems to me, would have been assured.

The school organization of the Jesuits became a tradition; the ratio studiorum and the ratio docendi were handed down. They have not written much on Paedagogy, but their system embodies a Paedagogy. That even in these days the Protestant intellect does not believe in a School of Education is shown by the opposition or indifference which the movement to instal education as a university subject has had to encounter, and by the fatuous and complacent satisfaction with which secondary schoolmasters have regarded their own ignorance of the principles and method of their art as more of a distincfion than a misfortune.

In the field of distinctively secondary education, I have said, the Jesuits were strong. Their higher or university instruction was also far from contemptible: they gave a thorough training in scholastic philosophy, theology, and the sciences to the members of the order; but, spite of the fact that there have been among them men eminent in many departments, they cannot be said to have succeeded as representatives of the higher intellectual ambitions of men. And this for the obvious reason that, as I have above indicated, all teaching was restricted within certain lines with a view to conserve the interests of the Roman Catholic Church. I do not say this by way of reproach : it could not have been otherwise, and they were fortunate in having a definite aim. Latin was the central subject, and the philosophy and theology of the schoolmen, especially of St Thomas Aquinas, bounded their vision. All else was either useless or dangerous to "The Faith." Now, it is essential to the advance of humanity that there should be freedom, and equally essential to a university as standing in the forefront of the movement of reason in the 
world, that there should be free teaching and free learning. Truth, and truth alone, whithersoever it leads, must be the aim of all intellectual activity.

Again, and for similar reasons, while the Jesuit order does not forbid, they have never advanced, the education of the masses. There is manifest danger to the Faith in so doing. Their purpose has been to get hold of those whose business is to lead and govern, while confining all others to the simplicities and crudities of faith and obedience.

Accordingly, we may say with confidence, that the essential characteristic of the humanistic revival (as I have tried to explain it) was alien to the Jesuit spirit, and that the Order was under obligation, in accordance with its own principles, to ally itself with arbitrary authority, despotism, and obscurantism. It is only while it does not possess the educational field to the exclusion of other and more modern forces that it can be regarded with complacency in a free country. And even as to their educational efficiency in the 16 th and 17 th centuries we may put against the encomium of Bacon the opinion of Leibnitz, who said that the Jesuits "fell below mediocrity," and the words of Macaulay, who said that the Jesuits seemed to have found the point to which they could push intellectual culture without reaching intellectual emancipation. All modern studies have been regarded with distrust. Obedience and Faith resting on Authority virtually sum up their educational aim. Formalism, consequently, characterises all their methods.

How remote the spirit and aims of the Jesuits were, and are, from the true spirit of the Humanistic Renaissance is evident enough the moment we recognize in this movement "the endeavour of man to reconstitute himself as a free being, not as the thrall of theological despotism, and the peculiar assistance he derived in this effort from Greek and Roman literature, the litterae humaniores, letters leaning rather to the side of man than of divinity ${ }^{1} . "$

1 Encyc. Brit., Art. Renaissance. 
The record of the Humanistic Revival in so far as it told on the schools repeats to us the old lesson that a new idea or a new enthusiasm is very efficacious while it lasts, but cannot long endure. Men cannot go on living at high pressure. It is only in so far as the new idea admits of rational formulation, or at least of being absorbed into the existing civil economy, whether of politics or learning, that it can perpetuate itself. Classical literature in the schools or universities came quickly to mean merely the classical tongues - a great gain when compared with mediaeval barrenness; but Latin and Greek certainly are not Humanism, but merely vehicles for Humanism. If the humanistic fervour-partly aesthetic, partly ethical-be not in the teacher, the whole teaching degenerates rapidly into language-teaching in its most abstract and uninteresting form. To all but the select few among pupils it thus conveys nothing, while engendering disgust of all books and all thought. This was a fact already before 1600 ; it is a fact now. The verbal, the abstract, the formal, is not mental food; it cannot, as such, be so. Its work is discipline; and this in itself is of little account if divorced from the real elements of literature and life.

No man interested in the progress of humanity can be indifferent to the question: Can we not so use the admirable and various material now in our possession as to excite in the majority of our pupils a genuine interest in literature, in thought, and in the truth of things? We cannot imperil the intellectual and moral welfare of generations on the chancebirth of teaching genius here and there. Is there a method by which learning would be as pleasant as eating when one is hungry, and which could be made the common possession of all who teach? If there be not such a method then we must just go on as we have been doing, trying to coerce the mind of youth; and failing even in this. Is it not possible that by making up our minds as to the end we have in view in educating, we may get some light on the method to be pursued in order to 
reach that end, nay get inspiration from the mere contemplation of it? These questions occurred vaguely to Bacon, and were taken up by the Baconians, Ratke, Comenius, Locke, Pestalozzi. The race of schoolmasters called these men "theorists"; and there an end. This was enough to condemn them. The questions which they started seem to me very important, nay vital questions, if we are to educate at all.

In endeavouring to answer the questions let us take advantage of history. Look at the universities of Europe at the present day. Whence comes their life, their progressiveness, without which there is no life? From Bacon and the Baconian induction and from vernacular literatures, I say without hesitation. It is the scientific spirit engaged in every department of human inquiry, physical, historical, philosophical, philological, aesthetic, that keeps them, in these days, centres of intellectual energy. With all their deficiencies, the learning of the world and all its highest rational interests were never so adequately represented in the universities as now. They are true centres of light, and why? Because they seek scientific results, and follow a scientific method. Method has done it all. Is this same method practicable in the school? If so, under what modifications? There is always a certain percentage of dullards-born in the good providence of God to be hewers of wood and drawers of water. But can we not touch to fine issues 70 or 80 per cent. of the youth of the country? It is certainly worth trying. In fact many schools, especially of the humbler kind, have been already converted by method (and that even imperfectly understood) from dens of darkness and despair into chambers of light and hope.

Whether education in the true sense is possible or not, this is certain, that until the secondary schoolmasters study the subject at our universities before entering on what they are pleased to call their "profession," an improvement which shall be genuine and progressive, because scientifically and historically grounded, is hopeless. Science and scientific method in all 
subjects alone prevent the world from falling back into barbarism. Pure literature itself might seem adequate to this; but even literature is only a part of the universal thought-movement, and has never flourished in its grander forms save as the artistic expression of a philosophy of life and of the earnest pursuit of truth. Take, for a painful example, Italy in the $15^{\text {th }}$ century.

To return: Meanwhile the vernacular and vernacular literatures of France, Germany and England had been growing up side by side with the classical revival, until it was found that the true meaning of the whole Renaissance movement, in so far as it was an Art, Literature, and Science movement, was to be found in modern art, modern literature, and modern science-not in the servile imitation of the Greek and Latin writers, though these were wisely retained in the schools as the foundation of linguistic discipline, as models of literary expression, and sources of modern thought. This was, and is, the true Humanism. The use of a more and more refined vernacular now also began to affect that exclusive use of Latin as a means of intercourse in the schools which gave colloquial familiarity with it, and which, even if it had done nothing else, had put into the hands of the student the key to all that had once been worth knowing. Knowledge in every department of human activity was advancing. It is clear enough to us, looking back, that the question of education demanded reconsideration in $\mathbf{1} 600$. Europe was passing into new conditions. In England the voice of Mulcaster was raised in advocacy of the study of English and the training of schoolmasters, but it was as that of one crying in the wilderness. There were now many, however, to express discontent with both school and university. The problem of education in its large and liberal sense must be always substantially the same; but the materials by means of which, and the conditions under which we are to educate, must be subject to continual modification. 


\section{CHAPTER IX.}

\section{MONTAIGNE, THE FRENCH RATIONALIST, $1533-1592^{1}$.}

Michel Montaigne was born in Perigord, 1533, and died in Bordeaux, 1592, in the 59th year of his age. He was the son of a landed proprietor. On succeeding his father he lived a retired life, free from all political and business harassment, on his paternal estate.

In due course he studied law, and was appointed a Councillor in the Parliament of Bordeaux when he was only 2 I years of age; but he soon gave up public life as unsuited to his temperament and genius. Educationally he is the true successor of Rabelais, who died when Montaigne was 20 years old.

Montaigne was an ardent student of ancient literature, and his essays are full of references and quotations. He was neither a scholar, nor a philosopher, nor a theologian, nor a politician. He had formed his ethical views mainly on Plutarch and Seneca, and was by nature and in his criticism of life more nearly allied to Horace perhaps than to any other man. If he is to be classed among the Philosophers he must be placed among the Epicureans rather than the Academics. His Essays treat of all sorts of subjects, and are discursive in their character. His way of looking at life was singularly fresh and original, and having no philosophical or political

1 The first edition of the Essays appeared in Bordeaux in 1580 . 
purpose to serve he set down his thoughts and observations as they occurred to him, simply and naively, not caring much to preserve consistency. The art in which he especially excelled was the art of living for the day.

The great essayist and sceptic continues, after a lapse of three hundred years, to speak to us with all the freshness of a contemporary. "We converse with Montaigne," says Hallam, "or rather hear him talk: it is almost impossible to read his essays without thinking that he speaks to us: we see his cheerful brow, his sparkling eye, his negligent but gentlemanly demeanour: we picture him in his arm-chair, with his few books round the room, and Plutarch on the table." As a man of letters, who is also in the best sense a man of the world, he stands alone. $\mathrm{He}$ is original and unique as a thinker, and at the same time a type of a class which he had done much to create. Though the class he represents may not be a large one, he yet gives expression to a way of estimating life which is a passing mood of all thoughtful minds. He thus leads a large constituency-all the larger that he makes no tyrannical demands, and warns the reader not to labour after even him. Few writers say so many wise things as Montaigne does, and no one appears so little solicitous about convincing others that his sayings are wise. His intellectual philosophy is essentially sophistical and sceptical, his morality conventional, and his moral philosophy epicurean.

We are not disposed, however, to allow to Montaigne, and such easy-going sceptics as he, the superiority to limitations which they affect. It is all very well to proclaim the impossibility of finding absolute truth, and to luxuriate in a cultured indifference, but as the foundation of such talk there lies a philosophical conviction as positive as that of the most ardent zealot. The conviction is that, doomed as man is to nescience, the happiness of each individual is for himself the only solid pursuit, and is to be at all hazards cherished. The standard of happiness will doubtless vary with the idiosyncrasies 
and circumstances of each man, but must always, with cultivated men, embrace equability of mind, balance of judgment, a kindly disposition to all with whom they are brought in contact, an indisposition to exertion for any purpose whatsoever as leading to certain disturbance and almost as certain disappointment, a horror of a "Cause," and a strict regard to the comforts of the animal economy generally. And these were, it seems to me, the characteristics of Montaigne, characteristics which belong to natures fundamentally cold and selfish, incapable of sacrifice. Intellectual scepticism is itself, in truth, an implicit dogmatism, and in the field of moral action it is a self-complacent epicurean dogmatism. No man, in truth, holds more tightly to a positive philosophy of life than Montaigne. Doubtless the attitude of inquiry, the que scais-je? gives a breadth and elasticity of mind and promotes a geniality of nature that have their charms. They are, however, the true possession only of those who are not "too sure" of anything. A steady sustained conviction that there is nothing admitting of conviction runs through Montaigne's life and writings, and he is in respect of this as positive as his neighbours. No man can build his house on shifting sand. Montaigne may in words defy us to find him in earnest, but he fails: for he never doubts his attitude of doubt, and he never loses his grip of his ethical standard such as it is. So far at least he is in sober earnest.

We should like sometimes to find this arch-philosopher of practical life-wisdom in earnest about other things than indifference, and we naturally seek for this quality of earnestness in his views of religion and politics-subjects which call forth the passions of men more than any other. But notwithstanding all that has been said and written on these points, I think we shall find that his whole mental attitude was such as to forbid definite conclusions even on those vital subjects. His Apology for Sebonde does not throw light on his personal religious beliefs. If readers are disappointed in their expectations of definite conclusions here, they have themselves to blame, for 
they search for something which his philosophy has beforehand told them not to expect. The fact seems to be that in religion he was strictly conventional, and in politics he was equally conventional. "For Heaven's sake," he might be supposed to say, "don't disturb the status quo; things are bad enough, I grant, but in seeking to make them better, you will probably make them worse. Let us go on from day to day, quietly meeting little difficulties as they arise, and making the best both of the good and of the bad. The practical guidance of life, in the interests of a universal bonhommie - that is our business."

If we prosecute our inquiry after the "earnest" side of Montaigne's character, we shall find it perhaps most conspicuous in a genuine desire to amend the condition of the poor (probably because their condition offended his sensibilities), and in his views on education. It is the latter with which we have to do here; but of both characteristics I would say that they were the fruit of his positive philosophy of negation. A happy, useful (provided usefulness did not call for too much exertion), practically wise life was his summum bonum, and it was this aim that unconsciously determined the substance of his educational theory. In considering, then, his views on education, we must keep Montaigne's personal character and theory of life before our minds. For education, as distinct from instruction, is a subject on which no man can possibly write without being, more or less consciously, controlled in all his utterances by his philosophy of man and of the meaning of human life.

So much is necessary for the proper understanding of Montaigne on education. But more than this is needed for the proper placing of him in the series of educational writers. We have to understand his historical relations and the circumstances of his life and time, of which receptive men like Montaigne are in a special sense the product and reflexion.

Luther died when Montaigne was thirteen years old. It was during the latter period of Luther's life that the Humanistic 
movement among the leaders of thought north of the Alps began to tell (as all great philosophic and political movements inevitably do sooner or later) upon the education of youth. The reformation of religion was itself, as we have seen, only part of the larger Humanistic movement. For Humanism was essentially a rebellion against words and logical forms in the interest of the realities of life and thought. The Italian Humanists and their pupils prepared the way for the Religious reformation. An intellectual movement of this kind could not fail to niake itself felt in education as well as in the domain of religion, for it was truly a philosophical movement; and philosophy ultimately determines all such things. Up to the period of university life, and even beyond it, education consisted in the acquisition of Latin words and rules about Latin, and this, as the boy grew, received the addition of logic with all its scholastic subtleties, and such physics as abridgments of Aristotle could supply. Prior to Montaigne's school-days the intellectual life of the schoolboy was, as may be supposed, very wretched; but those who survived it, and continued to devote themselves to grammar, rhetoric, and logic, certainly acquired an amount of discipline which could not fail to sharpen their wits. Intensity and subtlety of thought were the natural outcome of the educational system, but accompanied with a restricted range of view and a belief in arid terms and phrases. Luther's educational activity, like that of Erasmus and Melanchthon, was directed to aid the Humanists in reviving in the school a regard for substance as opposed to form. Pure Latinity, the study of the substance of the great Roman writers, and of rhetoric and logic by the perusal of those great products of literary genius out of which the rules of rhetoric and logic were themselves generalized, began (as previously in certain schools of Italy) to take the place of mere words and of barbarous Latinity. The typical schoolmaster of this period, though not the most enlightened, was John Sturm, the rector of the High School of Strasbourg, 
whose course of instruction, severe and mainly linguistic, was yet such as to give genuine culture to all those who were capable of culture. Sturm died in 1589 . Already the Humanistic movement in schools had been represented in England by Dean Colet, who died in 1519, after founding S. Paul's School and putting at its head Mr Lilly; by Sir Thomas Elyot, who died in 1546 ; and by Roger Ascham, who died in 1568, and was a correspondent of Sturm. Erasmus, the friend of Colet, and of all the Oxford Reformers, died in 1536 . Rabelais died in 1553. Montaigne's position is thus clearly defined. Born in 1533, and dying in 1592, he was in the midst of the full tide of the reaction against, what Milton calls, "the scholastic grossness of barbarous ages," "ragged notions and babblements"; and also, curiously enough, in the full tide of the Catholic reaction against Protestantism.

Montaigne's father, a gentleman of private estate in the province of Guienne, had notions of his own as to the education of the young Michel, and whatever we may think of them, the son thought highly of his father's method, and all through life retained the profoundest affection and respect for "the best father that ever was." He used to ride in his father's old military cloak, "because," he said, "when I have that on, I seem to wrap myself up in my father." His education, under the paternal roof, was directed morally to the cultivation in him of an intense love of truthfulness and of kindliness of feeling and manners towards the poor and dependent. So solicitous was the father to surround his child with every beneficent influence that he had him roused every morning by the sound of music, that there might be no violent disturbance of his nervous system. Montaigne further tells us the novel arrangements his father made for initiating him in the Latin language without straining his powers. He gave him a Latin-speaking tutor, and surrounded him with Latin conversation, so that when he was six years old he spoke Latin 
fluently-much better, indeed, than he could speak his own tongue. The whole household, indeed, became so Latinized that the domestics, and even the peasants on his father's property, began to use Latin words.

Greek was taught by the invention of a game, but it would appear without much success, for Montaigne's knowledge of Greek literature was never much more than he could obtain through a Latin medium.

$\mathrm{He}$ was only six years old when he was sent to the College of Guienne at Bordeaux, an institution of mark, in which the Humanistic culture must have reigned supreme, if we may judge from the names of the teachers-William Guerente the Aristotelian, Muretus the classical Latinist and rhetorician, and our own George Buchanan the historian and Latin poet ${ }^{1}$. At college he lost his familiar acquaintance with colloquial Latin, but largely extended his private reading in classical authors; this, however, only by a breach of school rules in which he was wisely encouraged by his masters. George Buchanan seems to have been his private tutor as well as his schoolmaster, and it says much for Buchanan that he encouraged young Montaigne's wide reading. At the early age of thirteen he had accomplished his college course, and although he afterwards affected to study law, it cannot be said that he had any special public instruction outside his professional reading after he was a boy. Had it not been for the wise connivance of his masters, which enabled him to make acquaintance with the literature of Rome, he would have "brought away from college nothing but a hatred of books, as almost all our young gentlemen do." His father was satisfied with the result of his school-life, "for the chief things he expected from the endeavour of those to whom he had delivered me for education was affability of manners and good humour." Montaigne was, to speak the truth, though not idle, yet desultory, and he would be the first to admit it. $\mathrm{He}$

1 Here also the father of Casaubon received his instruction. 
also complains that he had "a slothful wit that would go no faster than it was led, a languishing invention and an incredible defect of memory, so that it is no wonder," he adds, "if from these nothing considerable could be extracted." He was incapable of sustained effort and of taking much trouble about anything. Nor could it be said that, with all the leisure at his command, he was ever master of any subject : he had "only nibbled," he himself says, "on the outward crust of sciences, and had a little snatch of everything and nothing of the whole." Even of Latin he was not a master, and Scaliger speaks with contempt of his scholarship; to which, however, Montaigne never made any claim. His innumerable classical allusions and quotations were, however, the genuine fruit of his own reading ; but he read not as a grammarian or philosopher, but as a man of letters. "I make no doubt," he says, with his usual naïveté, " that I oft happen to speak of things that are much better and more truly handled by those who are masters of the trade.... Whoever will take me tripping in my ignorance will not in any way displease me; for I should be very unwilling to become responsible to another for my writings, who am not so to myself nor satisfied with them. Whoever goes in quest of knowledge, let him fish for it where it is to be found: there is nothing I so little profess." Again, "I could wish to have a more perfect knowledge of things, but I will not buy it so dear as it will cost. My design is to pass over easily, and not laboriously, the remainder of my life. There is nothing that I will cudgel my brains about ; no, not knowledge of what price soever. . . I do not bite my nails about the difficulties I meet with in my reading, and after a charge or two I give them over. . . Continuation and a too obstinate endeavour darken, stupefy, and tire my judgment."

The moral result was more satisfactory. Montaigne's disposition was naturally kindly, and its kindliness was further fostered by his father's affectionate upbringing. If ever there was a man distinguished for "sweet reasonableness" that 
man was Montaigne. He had the light of culture and also its sweetness.

I have dwelt a little on Montaigne's own character, because that has to be taken into consideration along with the circumstances of his time, in forming a true estimate of his educational opinions. The character of the man, also, is itself to be regarded as, to some extent at least, the fruit of his education, and retrospectively his father's method comes up for judgment according to the saying, "By their fruits ye shall know them." It is sufficiently clear that of discipline, intellectual or moral, Montaigne had received none, and that his nature was one that stood in some need of it. On the other hand, the love that his father bore him and the gentleness of his treatment unquestionably nurtured the ingenuous spirit of his son and gave him a freedom of judgment and a frankness of intelligence which are among Montaigne's principal charms. His mind was not at any time oppressed with too strong a burden of duty or warped by fear. He grew up into an open-eyed, gentle, and sweetblooded man, with a sound practical judgment-a wise man, if not a learned one-capable of looking at every side of a question by turns and dallying with each.

But to follow the example of Montaigne's father would not always succeed. He had a man of genius as his child and pupil, and all he did was felicitously adapted to develop the boy's natural endownents. But the system pursued did not cure the pupil's manifest defects of character. Even his natural weakness of memory, so far from being remedied, was probably increased by the father's lax treatment. Perhaps all the better for the world, it may be said. In this particular case it was so; but we have not young Montaignes to deal with. We have to discipline the intellectual and moral nature of the average boy if we would give energy of will, earnestness of purpose, power of application, and love of duty. 
When Montaigne gives us his own views' on the education of the young we find them to be very much a reflex of his own experience and character. I shall speak of them as they bear on the end of education, on the materials of instruction, on method, on intellectual and moral discipline, and on the penalties whereby the work of the school is usually enforced. One thing is certain, that on the subject of education Montaigne had no doubts: on the contrary, he speaks with all the zeal of a reformer.

If we were to put in the shortest form Montaigne's idea of the End of education we should say that it is this : that a man be trained up to the use of his own reason and to virtue. "The trouble and expense of our fathers are directed only to furnish our heads with knowledge; not a word of judgment and virtue." "A man," he says, "can never be wise save by his own wisdom." Might we not add, A man can never be virtuous save by his own virtue? Again, "If the mind be not better disposed by education, if the judgment be not better settled, I had much rather my scholar had spent his time at tennis, for at least his body would by that means be in better exercise and breath. Do but observe him when he comes back from school, after fifteen or sixteen years that he has been there: there is nothing so awkward and maladroit, so unfit for company and employment; and all that you shall find he has got is, that his Latin and Greek have only made him a greater and more conceited coxcomb than when he went from home. He should bring back his soul replete with good literature, and he brings it only swelled and puffed up with vain and empty shreds and snatches of learning, and has really nothing more in him than he had before." The author of Hudibras, when he wrote the following lines, gave expression to the impatience of both Montaigne and Milton :-

1 Chiefly in chapters 24,25 of the First Book. 
"No sooner are the organs of the brain Quick to receive and steadfast to retain Best knowledges, but all's laid out upon Retrieving of the curse of Babylon.

And he that is but able to express

No sense in several languages,

Will pass for learneder than he that's known To speak the strongest reason in his own."

It is true that great men and vigorous natures overcome the defects of their schooling; but "it is not enough that our education does not spoil us, it must alter us for the better." "It is not enough to tie learning to the soul, but to work and incorporate them together; not to tincture the soul merely, but to give it a thorough and perfect dye; and if it will not take colour and meliorate its imperfect state, it were, without question, better to let it alone." Knowledge will not "find a man eyes; its business is to guide, govern, and direct his steps, provided he have sound feet and straight legs to go upon." Neither Persia nor Sparta, I may interpose, made much account of mere knowledge, and Rome was at its greatest in virtue and vigour before schools were much thought of. To train to valour, honesty, prudence, wisdom, justice-these were the aims of the greatest nations. As Agesilaus said when asked "what boys should learn": "Those things" (he said) "that they ought to do when they become men."

Montaigne, then, would keep in view the end of education from the very first ; and that end is to train to right reason and independent judgment, to moderation of mind, and to virtue. The cultivated and capable man of affairs, fit to manage his own business well and discharge public duties wisely, is his educated man. This is the antique idea of education, and is very much what Quintilian has in view in the training of the "Good Orator." Philosophy, according to Montaigne, is the highest fruit of education - not the philosophy which has logical 
formulae for its subject-matter, but philosophy which has virtue for its end. Virtue and philosophy are not (to use Milton's words) "harsh and crabbed as dull fools suppose," but the "enemies of melancholy and the friends of wisdom: they teach us how to know and make use of all good things, and how to part with them without concern." "Philosophy instructs us to live, and infancy has there its lessons as well as other ages." We are not, however, to force to virtue and to philosophy, but to attract by showing that they alone yield happiness, and by leading the pupil to recognize their essential beauty and charm. It may be that there are youths who are inaccessible to all that is noble and beautiful and ingenuous in thought and action, and turn aside by preference to common pleasures. What is to be done with these? "Bind them 'prentice," says Montaigne, "in some good town to learn to make mince-pies, though they were the sons of dukes"; and in a manuscript emendation he recommends that the masters should "strangle such youths if they can do it without witnesses"!

What now has Montaigne to say as to the Materials of instruction whereby his end is to be attained? "The most difficult and most important of all human arts is education," he says. The differences among children increase the difficulty; but the promise of the future is with young children so uncertain that it is better, so far as the matter of instruction goes, to give to all the elements of knowledge alike. In any case, let us begin when they are young, when the clay is moist and soft. From the very first, the lessons of philosophy in their simple and practical form can be inculcated. In philosophy Montaigne includes all that we now understand by the religious and moral, and he maintains, and rightly maintains, that a child's mind is more open to all such lessons than to reading and writing. In selecting other materials of instruction, we must bear in mind that a child "owes but the first fifteen or sixteen years of his life to discipline, and the rest to action. Let us, therefore, 
employ that time in necessary instruction." At every stage that which constitutes the ultimate aim of education is to appear in some form or other-philosophy, namely; for it forms the judgment and conduct. This has a hand in everything: "She is always in place, and is to be admitted to all sports and entertainments because of the sweetness of her conversation. By guiding conduct, as well as by discourse in season, this instruction is to be given and habits thus formed."

Montaigne is generally classed by educational writers as a realist -as the very founder of realism. Those who so write, write, it appears to me, without understanding. Educational realism in our modern sense means the substitution of a knowledge of nature and of the practical work of after-life for the study of language and literature and all that we include in the Humanities. 'Those who advocate the latter are Humanists, and are the true descendants of the Humanists of the Renaissance. All educationalists, however (except, perhaps, the majority of schoolmasters), are realists in this sense--Montaigne's sensethat they desire to see reality, that is, to see the substance of fact and thought dominant in the education of youth. Montaigne's realism opposed itself merely to verbalism, and he fought a good fight in this. But all this belongs to the past; in the region of educational theory at least, whatever may be said of practice. We all now seek reality; we are all opposed to mere verbalism. The difference now consists in this, that one school of philosophy holds by language and literature as introducing youth to the highest and best realities - the realities of feeling and thought; the other school holds by facts, the facts of nature and of man's relation to nature as yielding the highest and best realities for educational purposes. If we may make a distinction between the real-humanistic and the verbal-humanistic, there can be no doubt that Montaigne belonged, like Quintilian, to the former class, and not to the utilitarian realists of whom Mr Spencer and Professor Bain are the best contemporary types. 
The ordinary subjects of reading, writing, and casting accounts are, of course, to be taught. After this, whatever you teach, avoid words simply as words. So far Montaigne and Bacon would agree. Most modern Humanists, however, would not go so far as Montaigne in their opposition to words. They see more in them. But we must bear in mind the state of things at the time Montaigne wrote. The Humanistic revival, which was a revival in the interest of realities, was also a revival of style; and the tendency was to give prominence to art in language, and consequently to what may be called the formulas of style. This must always be the case : teachers in their daily work cannot, without the greatest difficulty, consistently maintain from hour to hour the reality of any subject, be it language, literature, or science. The tendency inevitably is to fall back upon mechanical expedients, on the learning of rules, and on symbolism generally. It is so even with religion and morality. To the end of time, the task of the true teacher, who desires truly to educate, will be a struggle against the dominion of words and forms, and this quite irrespectively of the subjects he may choose to make the basis of his school-work. The virtues of the educational profession are all summed up in the words-life, reality; but, like other virtues, they are not always easily practised.

"The world," says Montaigne, "is nothing but babble.... We are kept four or five years to learn nothing but words and to tack them together into clauses; as many more to make exercises, and to divide a continued discourse into so many parts ; and other five years, at least, to learn succinctly to mix and interweave them after a subtle and intricate manner. Let us leave this to the learned professors!" Words, grammar, style, and rhetoric constituted the main end of school and college instruction in those days, and this was supplemented by logic. Montaigne held that if a man had really anything to say he could manage to say it without all this training. "Let the pupil be well furnished with things" (i.e. thoughts), he says, 
"words will follow but too fast." People who pretend to have great thoughts which they cannot express are deceiving them: selves; they are not labouring to bring forth, but merely "licking the formless embryo" of their minds. If a man has any clear conceptions, he will express them well enough, though ignorant of "ablative, conjunctive, substantive, and grammar." "When things are once formed in the fancy, words offer themselves in muster." "Ipsae res zerba rapiunt," says Cicero. "The fine flourishes of rhetoric serve only to amuse the vulgar, who are incapable of more solid and nutritive diet." 'The attack on mere rhetoric in the sense of the technique of style is keen and incisive, and has not a little truth in it. "Words are to serve and to follow a man's purpose." He quotes Plato as approving of fecundity of conception rather than of fertility of speech, and Zeno as dividing his pupils into two classes, the philologi, who loved things and reasonings, and logophili, who cared for nothing but words. "I am scandalized," he says, "that our whole life should be spent in nothing else."

What would he have, then, in addition to the usual elements of all education, and the teaching of philosophy and of virtue? He would have a man learn thoroughly his own language first, and then that of his neighbour, regarding Greek and Latin as ornamental merely. Little, however, did Montaigne think that instruction, even in our own language, could degenerate into what it has become in these latter days-verbalism of a kind much more offensive than any to be found in classical teaching. He could not foresee detailed analysis of sentences, and the dreary pedantry of the school grammars of our native tongue. Paedagogic ingenuity had not yet invented such arid substitutes for the substance and living form of our motherspeech-arch-enemies of true humanistic culture-the logical babblement of the primary school. Truly teachers have an "infinite capacity for sinking."

Vernacular and modern languages once secured, Montaigne 
would thereafter limit the course of study "to those things only where a true and real utility and advantage are to be expected and found. To teach a boy astronomy, for example, instead of what will make him wise and good, is absurd. After you have done this last, the pupil may be admitted to the elements of geometry, rhetoric, logic, and physics; and then the science which his judgment most affects he will generally make his own." But we must above all teach him "what it is to know and what to be ignorant, what valour is, and temperance and justice; the difference between ambition and avarice, servitude and subjection, licence and liberty ; in brief, season his understanding with that which regulates his manners and his sense, that which teaches him to know himself, and how both well to die and well to live. Over and above this, let us make a selection of those subjects which directly and professedly serve for the instruction and use of life." But the direct instruction of the master is not all. "Human understanding is marvellously enlightened by daily conversation with men, for we are otherwise of ourselves so stupid as to have our sight limited to the end of our own noses. One asking Socrates of what country he was, he did not make answer 'of Athens,' but 'of the world.'" We must learn to measure ourselves aright: "whosoever shall represent to his fancy, as in a picture, that great image of our mother Nature portrayed in her full majesty and lustre, whoever in her face shall read her so universal and constant variety, whoever shall observe himself, and not only himself but a whole kingdom, no bigger than the least touch or prick of a pencil in comparison with the whole,-that man alone is able to value things according to their true estimate and grandeur." The great world is the mirror wherein we are to behold ourselves, to be able to know ourselves as we ought to do. History naturally suggests itself in this connexion as a leading subject of study, for "thereby we converse with those great and heroic souls of former and better ages"-an empty and an idle study as commonly conducted, but of "inestimable 
fruit and value" when prosecuted with care and observation. The object of history-teaching in the school is not facts, but the appreciation of historical characters.

Meanwhile the body is not to be forgotten, for, not to speak of the moral instruction which may be conveyed in connexion with leaping, riding, wrestling etc., we have to form the youth's outward fashion and mien at the same time as his mind: for "'tis not a soul, 'tis not a body we are training only, but a man, and we ought not to divide him." And, as Plato says, "we are not to fashion one without the other, but make them draw together like two horses harnessed to a coach." "It is not enough to fortify the soul: you are also to make the sinews strong, for the soul will be oppressed if not assisted by the bodily members, and would have too hard a task to discharge two offices at once." Effeminacy in food or clothes or habits is also to be eschewed.

So much for the end of education according to Montaigne, and the materials of instruction whereby that end is to be attained. Montaigne's public school, if he had to construct one in these days, would certainly be somewhat after the fashion of a German Real school, as regards its external organization, and, so far, he is rightly named a realist. But the leading purpose of all his instruction would essentially be ethical and humanistic. The only respect in which his curriculum would be realistic in the utilitarian meaning would be in the subordinate place assigned to Latin and Greek. So far is he from being a Realist in the modern sense, that he may be rather set down as an enemy of mere knowledge or information. "The cares and expense our parents are at in our education, point at nothing save to fill our heads with knowledge," he says, "but not a word of judgment or virtue. We toil and labour to stuff the memory, and in the mean time leave the conscience and the understanding unfurnished-void."

It has to be noted that Montaigne, and after him Milton and Locke, think only of the education of the few and not of 
the many-of the sons of gentlemen only : but we may remark that, while the extent to which school instruction is carried depends for the most part on the social position of the parent, the principles which regulate a prolonged education are equally operative in the briefest, if they are worth anything at all as principles.

Of equal importance with end and means is Method. On this Montaigne has less to say, but what he says contains probably the germs of the most important principles of all method.

" "Tis the custom of schoolmasters to be eternally thundering in their pupils' ears as if they were pouring into a funnel, whilst the business of the pupil is simply to repeat what the teacher has before said. I would have a tutor correct this error, and at the very first he should, according to the capacity he has to deal with, put it to the test, permitting his pupil himself to taste and relish things and of himself to choose and discern them, sometimes opening the way to him and sometimes making him break the ice himself; that is to say, I would not have him alone to invent and speak, but also hear his pupil invent and speak in his turn. Socrates, and since him Arcesilaus, made first their scholars speak and then they spoke to them. The authority of those who teach is very often an impediment to those who desire to learn. It is good to make the pupil, like a young horse, trot before the master, that he may judge of his going and how much he, the master, is to abate of his own speed to accommodate himself to the vigour and capacity of his pupil. For want of this due proportion we spoil all: to know how to adjust this and to keep within an exact and due measure is one of the hardest things I know ; and it is an effect of a judicious and well-tempered soul to know how to condescend to the boy's puerile movements and to govern and direct them. Those who, according to our common way of teaching, undertake with one and the same 
lesson and the same measure of direction to instruct several boys of differing and unequal capacities, are infinitely mistaken in their method; and at this rate it is no wonder if, in a multitude of scholars, there are not found above two or three who bring away any good account of their time and discipline." Here we have the foreshadowing of the organization of instruction and the classification of pupils. The importance of examination as a part of good method is also insisted on. "Let the master," he says, "not only examine him about the grammatical construction of the bare words of the lesson, but about the sense and meaning of them, and let him judge of the profit he has made, not by the testimony of his memory, but of his understanding. Let him make the pupil put what he hath learned into a hundred several forms, and accommodate it to many subjects to see if he yet rightly comprehend it and have made it his own, taking instruction in his progress from the "Institutions of Plato." "Tis a sign of crudity and indigestion," he says, "to vomit up what we eat in the same condition it was swallowed down, and the stomach has not performed its office unless it have altered the form and condition of what was committed to it to concoct." "What is the good of having the stomach full of meat if it do not nourish us?" Here we have what used to be called the "Intellectual method" anticipated, the importance of assimilation enforced, and the distinguishing characteristic of cram well exposed. Montaigne, further, in opposition to theories of education still current, advises that the pupil be made to sift and examine for himself, and to accept nothing on mere authority. "We can say, Cicero says thus: that these were the manners of Plato: that these, again, are the very words of Aristotle: but what do we say ourselves that is our own? What do zee do? What do we judge? A parrot would say as much."

So much for the method of intellectual instruction. The method of moral teaching is summed up in the words that it should "insensibly insinuate" itself in so far as it is direct, as 
lessons do which are not set and formal, but suggested by time and place.

Of intellectual and moral discipline, in the true sense of that term, we find in Montaigne nothing. Nor does religion, in any true sense, or a high ideal of personal life enter into his scheme of education. And when we have said this, we convict him of having left unwritten the two chief chapters in educational theory. These grave omissions the character and upbringing of the man would lead us to expect ; and we must not quarrel with what we have, because it falls short of all our demands.

With respect to Discipline, in the vulgar school sense-that is to say, the means taken to force boys to do what their masters want then to do-Montaigne takes up a position substantially the same as that of the great majority of eminent writers on education. $\mathrm{He}$ is persuaded that, by following a good method, instruction will become pleasant, and that it will not be difficult to allure the pupil to both wisdom and virtue. "If you do not allure the appetite and affection," he says, "you make nothing but asses laden with books, and, by virtue of the lash, give them their pocket full of learning to keep ; whereas, to do well, you should not merely lodge it with them, but make them to espouse it." Physical punishment fails of its aim, and must fail by the nature of the case. If it be necessary at any time to punish a child, it should be done when we are calm. "No one," he says, "would hesitate to punish a judge with death who should have condemned a prisoner in a fit of passion. Why is it allowed any more to parents and masters to beat and strike children in their anger? That is not correction : it is revenge. Chastisement stands to children in the place of medicine; and should we endure a physician who was angry and violent with his patient?" "Education," he says elsewhere, "should be carried on with a severe sweetness, quite contrary to the practice of our pedants, who, instead of 
tempting and alluring children to letters by apt and gentle ways, do, in truth, present nothing before them but rods and ferules, horror and cruelty. Away with this violence! away with this compulsion! than which nothing, I certainly believe, more dulls and degenerates a well-descended nature. If you would have the pupil alive to shame and chastisement, do not harden him to them. . . The strict government of most of our colleges has even more displeased me; and peradventure they might have erred less perniciously on the indulgent side. The school is the true house of correction of imprisoned youth. .. I Do but come in, when they are about their lesson, and you shall hear nothing but the outcries of boys under execution, with the thundering noise of their pedagogues, drunk with fury, to make up the concert. A very pretty way this to tempt these tender and timorous souls to love their book-with a furious countenance and a rod in hand! A cursed and pernicious way of proceeding!... How much more decent would it be to see their classes strewn with green leaves and fine flowers, than with the bloody stumps of birch and willows! Were it left to my ordering, I would paint the school with the pictures of Joy and Gladness, Flora and the Graces, that where the profit of the pupils is, there might their pleasure also be."

We are all of Montaigne's opinion nowadays; for he did not forbid punishment or coercion, in some form or other, when all other means failed. Extrema in extremis. $\mathrm{He}$ merely protested against the scholastic tyranny of his time (and we may say of all time, as may be learned from almost every writer on education for the last 2000 years) - a tyranny still existing, and till lately prevalent. Slave-driver and schoolmaster were almost convertible terms. The school and the rod were ideas of inseparable association. Samuel Butler calls "whipping"

"Virtue's governess,

Tutoress of arts and sciences." 
"Oh! ye" (says Byron) "who teach the ingenuous youth of nations, Holland, France, England, Germany, and Spain,

I pray ye flog them upon all occasions :

It mends the morals; never mind the pain."

Thomas Hood, again, in looking back on his school-days, recalls chiefly his floggings; and yet his pleasant humour can call up some sentimental regret :-

\section{"Ay, though the very birch's smart Should mark those hours again, I'd kiss the rod, and be resigned Beneath the stroke, and even find Some sugar in the cane."}

The subject, however, is too serious for jocular treatment. Before Montaigne's day, and long after it, the brutality of schoolmasters was such as to leave an almost indelible stain on the profession. The whole body should make an annual pilgrimage of penitence for the sins of their predecessors. Schoolmasters are now beginning to understand that it is only by balanced temper and by sound method that they can dispense with physical motives, and out of the more or less contemptible "dominie" of the past, evolve the educator of the future. In no other way certainly can they make good their claim to that social position which they, often too morbidly, claim. A mere castigator puerorum has no claim to anything save his wages, which should be the minimum for which he can be hired.

Montaigne's educational views were defective, certainly, though in substance and in their main purpose sound. The defects, as before observed, may be traced to his own upbringing and character. Everything with him is too easy. Wisdom's ways, alas! are not always ways of pleasantness, nor are her paths always those of peace. 'The easy and harmonious way of life of Montaigne is for a few fortunate souls only. We have to train our boys to work hard, to will vigorously, to be much in earnest, to have a high sense of duty. Such qualities do not come by wishing. By intellectual and moral discipline, 
by inducing him to do what may be disagreeable, by requiring obedience, by enforcement of law, we have to mould our British boy. For all this kind of work Montaigne has little to teach us ; but we can learn much from him, and we part from the wise and kindly Frenchman with gratitude, and even affection.

To one taking a survey of the history of education it is interesting to note that Montaigne was brought up in a Humanistic school taught by men who stood high in Europe as Humanists, and yet he has nothing but hard words for the system. When Montaigne was at school, Humanism in education was at high tide north of the Alps. We may learn from him that the revival was restricted in its aims and not wholly successful. As I have said elsewhere: a simpler grammar than that popular in previous centuries and the substitution of classical Latin authors for bad Latin and a little Greek sums up the revival so far as all save a few schools were concerned. They still had much to learn from Quintilian, of whom Montaigne sometimes reminds us. An important advance had been made, but containing in it the seeds of relapse. For even with an improved grammar, abstract rules and the study of words for their own sake would still hold sway, and when the freshness of the new movement had worn off the inevitable result would be the restoration of the rule and the whip. The only true and permanent reform of education must comprehend not only a reform of Method but a school of Method at our universities. The need of a method well thought out was felt as we have seen by Ascham, but it was not till Bacon arose that method on a scientific basis became possible. 
THE MODERN PERIOD, FROM I600 A.D. 


\section{CHAPTER X.}

\section{THE MODERN PERIOD, FROM I600 A.D.}

THE characteristics of what may be called the Modern Period in education are I think the following:

ist. Belief in the power of mere knowledge to educate the human mind.

2nd. A tendency to exalt the sense-realistic, and consequently to advocate the study of physical science as opposed to the Humanities.

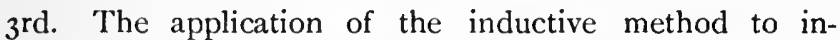
struction.

These doctrines of the Modern School of Naturalists derive themselves from the Baconian philosophic movement, although Bacon himself would be the first to repudiate its advocates as his legitimate descendants. It is only in recent years that they have had any success. Conservative narrowness has held the citadel of the Schools against the equally narrow aggressiveness of the Liberals. In the impending reorganization of educational systems, the victory will go to neither party.

FRANCIS BACON, $1561-1626$.

In 1605 there appeared a book which was destined to place educational method on a scientific foundation, although its mission is not yet, it is true, accomplished. This was Francis Bacon's Advancement of Learning, which was followed, 
some years later, by the Organon. For some time the thoughts of men had been turning to the study of Nature. Bacon represented this movement, and gave it the necessary impulse by his masterly survey of the domain of human knowledge, his pregnant suggestions, and his formulation, imperfect as it was, of scientific method. Bacon was not aware of his relations to the science and art of Education; he praises the Jesuit schools, not knowing that he was by his philosophy subverting their very foundations. We know inductively: that was the sum of Bacon's teaching. In the sphere of outer Nature, the scholastic saying, Nihil est in intellectu quod non prius fuerit in sensu, was accepted, but with this addition, that the impressions on our senses were not themselves to be trusted. The mode of verifying senseimpressions, and the grounds of valid and necessary inference, had to be investigated and applied. The educational bearing of this is manifest ; for it is clear that if we can tell how it is we know, it follows that the method of intellectual instruction is scientifically settled.

Bacon himself says, writing to Lord Burleigh in $1592,-$ "I have as vast contemplative ends as I have moderate civil ends, for I have taken all knowledge to be my province; and if I could purge it of two sorts of rovers, whereof the one with frivolous disputations, confutations and verbosities (the schoolmen), the other with blind experiments and auricular traditions and impostures (unmethodical investigators, e.g. alchemists, astrologers, etc.) hath committed so many spoils, I hope I should bring in industrious observations and profitable inventions and discoveries - the best state of that province. 'This... is so fixed in my mind that it cannot be removed." And in his letter to Toby Matthews in 1609 he says, - "......the question between me and the ancients is not of the virtue of the race, but of the rightness of the way." As the philosopher of Realism and of the Inductive method, Bacon, it may be, only summed up the thoughts and practice of several pre- 
decessors; but he was the man of genius who (as frequently happens) gathered up those hints, anticipations and aspirations which constitute a "tendency," and gave them shape.

In the department of education one of the chief services Bacon rendered was his including it among the sciences to be studied. It was by him called "tradition"-the handing down of the acquired intellectual possessions of mankind to those who are to be our successors. But this was not all; for, in speaking of this subject, he was naturally influenced by the new gospel of the real-of the founding of knowledge on seeing for ourselves what was there before us, and basing our conclusions on accurate observation, and a sound method of rational procedure. Nature was no longer to be studied by means of divisions and definitions of hastily formed concepts, and compelled to fit itself into premature axioms in which the very processes of nature were forestalled. Generalization was to follow only in the wake of carefully observed facts. "Man," he says, in the Novum Organum, "who is the servant and interpreter of Nature, can act and understand no further than he has, either in operation or contemplation, observed of the method or order of Nature." And again, "Men have sought to make a world from their own conceptions and to draw from their own minds all the materials which they employed; but if instead of doing so, they had consulted experience and observation, they would have had facts and not opinions to reason about, and might have ultimately arrived at the knowledge of the laws which govern the material world...... Thus they may hope to arrive at principles......luminous and well defined, such as Nature herself will not refuse to acknowledge." But Bacon did not invent Induction any more than he invented the human mind; he, however, unquestionably gave to the world the Logic of Induction and formulated the practice of Galilei and the premonitions of $\mathrm{Da}$ Vinci. $\mathrm{He}$ was, as Isaac Walton called him, "the great secretary of Nature and Science." 
To speak of the Baconian induction as Goethe did, is to misapprehend it. It is true that to the man of genius one fact is worth a thousand to the uninspired laboratory hodman, and that the laborious collection and comparison of "instances" is not always necessary. On the other hand, it is equally true that the flashes of insight, which enable a great man to put his finger on the true cause and ultimate generalization in any department of knowledge, are simply swift anticipatory inductive processes. Nor will any "flash of insight" ever be accepted by the world as objective truth, until it has been indirectly verified and established by the reverse process of Deduction--that is to say, by applying the supreme generalization to the elucidation of lower generalizations, and ultimately of individual facts, thereby showing that it truly explains them by containing them.

Bacon was not in his reform of Method thinking of psychology and the manner in which the mind attains to knowledge: he had his eye fixed chiefly on the matter itself of knowledge, and he saw that it was inductively, and by various steps of inductive activity, that what was presented to the senses received its verification. This, and this only, was the way in which we knew a thing for certain. It no doubt followed from this that we should teach inductively; but it was to Bacon's successors that we owe the full exposition of what was implicit in Bacon's thought. Bacon and his school were thus, I hold, the founders of modern method in education-not as based on reflective psychology, but rather as revealed by the actual process whereby the truth of things was ascertained. He looked at the matler of thought, not at the thinking process. A more advanced psychology claims in these days to ground the realistic or inductive method of inquiry and instruction on a study of abstract mind itself, on a criticism of knowing, and so to extend its sphere and supplement its defects.

Bacon and the Baconians, in short, occupied themselves with the Content, not the pure Form, of Thought, and found 
their method in the zeay in which things were truly known. They fixed their attention on things as growing into the thought or truth of themselves in our minds, not on thought or thinking as such.

We thus find in Bacon the pregnant seeds of reforms both as regards the substance and method of education. $\mathrm{He}$ attacks the universities as still the home of scholastic traditions and futile sophistries; he sketches a pansophic ideal; he points to the importance of method; he recognizes teachers as students of an Art; he points the way to realistic studies:-above all, he has faith in the future. It is these ideas which we find taking practical shape in his successors.

Allowing all possible credit to his precursors, Ludovicus Vives, Da Vinci, Galilei and others (and to certain contemporaries whom he strangely ignores), we yet recognize in Bacon the true Father of Modern Method. He represents the transition from the old world to the new, and more than any other man is to be revered as the "first of the Moderns"; and this not only in the large sphere of investigation generally, but in the narrower sphere of the School, with which we have here to do. That we now enter on the distinctively "modern" period of European intellectual activity is sufficiently attested by the great names in every department of investigation. It was not by accident, but rather in accordance with the natural evolution of mind, that we find almost as contemporaries Galilei, Bacon, Descartes, Boyle, Kepler, and Hugo Grotius.

It seems to me that, while we certainly fail to find in Bacon a developed system of education correlated with the method of the sciences, we yet encounter in the Advancement of Learning, in the conclusion of the sixth book of the $D e$ Augmentis (the Latin translation of the Adrancement extended), in the Essay on Studies, and in the letter to Savile (Provost of Eton), many pregnant hints which suggest a method, as well as 
a curriculum, of instruction. In the De Augmontis, for example, he gives the preference to the teacher who "transplants knowledge into the scholar's mind as it greas in his own." "A gardener, again," he says, "takes more pains with the young than with the full-grown plant, and men commonly find it needful in any undertaking to begin well." And on the training of teachers he adds, "We give scarce a thought to our teachers and care little for what they may be; and yet we are for ever complaining because rulers are rigid in the matter of laws and penalties, but indifferent to the right training of the young." The importance of proceeding from the more easy to the more difficult in learning, and the mental effects of different kinds of studies, are also adverted to. And as to subjects, it was no difficult matter for his followers to recognize in their master an advocate for realities in the school: "Be not wrapt up in the past; there is an actual present lying all about you, look up, and behold it in its grandeur."

If encyclopaedism or pansophy, that is to say, the correlation of sciences in a unity as taught in that encyclopaedic university of which Bacon has a brilliant vision in the Neze Atlantis, was the ultimate resting-place of the adult mind, it was only one step to the conclusion that the education of the young should be so begun and conducted as to lead to this Great Temple of all Knowledge. A broad realistic foundation was thus necessary. Education he calls an "early custom"; it is all important then that the custom should be a wise custom from the beginning. Here we have the germ of much in Comenius.

We read the history of educational thought in its relation to wider movements with small intelligence, if we do not see in Bacon the gatherings of the fruits of the renaissance movement in so far as it was a study of the realities both of things and thoughts, - a groping after reality both in science, philosophy and literature; and further, detect in all this a formulation of intellectual Protestantism. Authority, as such, was not in 
precise terms set aside, but its doom was fixed wherever the New Method was heartily accepted. The truth, as founded on an ever-fresh and an ever-growing study of the facts of nature and mind, was now and henceforth to be the sole aim of thinkers in every field of inquiry. The opinions of Colet, More, and Erasmus were about to become the convictions of all educated men, but now carried into spheres of thought which these men had not contemplated. Authority, tradition, even revelation had all to be thrown into the melting-pot, not by an individual here and there in advance of his time as in the previous centuries, but by the method and general consensus of the age. Thus it is that we, for the most part, find an intense Protestant feeling in those who advocated educational reform in the method and substance of instruction on Baconian lines. Ratke and Comenius are in scholastic matters representative of the school of Bacon in a wider than in a school sense. They are the reformers of the schools, it is true, but always with an eye to social and ecclesiastical, if not also political, changes. The Humanists, on the contrary, after their first efflorescence, ranged themselves with the conservative reaction, and Loyola himself found no difficulty in annexing much of their territory in the interests of Obscurantism.

We need not fear the result of this free investigation. So long as the recognition of the fact that the true life of man is a life in the ideals which we call philosophy and literature survives, the purpose of education will be found where the true life of man himself lies; that is to say, in philosophy and literature. The past, accordingly, will for ever retain its hold. It is essential that it should do so, if humanity is not to revert to barbarism. ${ }^{1}$

I think I shall now best serve the student of education by bringing together those passages in Bacon which give a general indication of his contribution to the subject.

1 Every student of Education should read the Advancement of Learning (Aldis Wright's Edition). 


\section{UNIVERSITIES, ETC.}

"First therefore, amongst so many great foundations of colleges in Europe, I find strange that they are all dedicated to professions, and none left free to arts and sciences at large. For if men judge that learning should be referred to action, they judge well; but in this they fall into the error described in the ancient fable, in which the other parts of the body did suppose the stomach had been idle, because it neither performed the office of motion, as the limbs do, nor of sense, as the head doth : but yet notwithstanding it is the stomach that digesteth and distributeth to all the rest. So if any man think philosophy and universality to be idle studies, he doth not consider that all professions are from thence served and supplied. And this I take to be a great cause that hath hindered the progression of learning, because these fundamental knowledges have been studied but in passage. For if you will have a tree bear more fruit than it hath used to do, it is not anything you can do to the boughs, but it is the stirring of the earth and putting new mould about the roots that must work it. Neither is it to be forgotten, that this dedicating of foundations and ditations to professory learning hath not only had a malign aspect and influence upon the growth of sciences, but hath also been prejudicial to states and governments. For hence it proceedeth that princes find a solitude in regard of able men to serve them in causes of estate, because there is no education collegiate which is free; where such as were so disposed mought give themselves to histories, modern languages, books of policy and civil discourse, and other the like enablements unto service of estate.

"And because founders of colleges do plant, and founders of lectures do water, it followeth well in order to speak of the defect which is in public lectures; namely, in the smallness and meanness of the salary or reward which in most 
places is assigned unto them; whether they be lectures of arts, or of professions. For it is necessary to the progression of sciences that readers be of the most able and sufficient men; as those which are ordained for generating and propagating of sciences, and not for transitory use. This cannot be, except their condition and endowment be such as may content the ablest man to appropriate his whole labour and continue his whole age in that function and attendance; and therefore must have a proportion answerable to that mediocrity or competency of advancement, which may be expected from a profession or the practice of a profession. So as, if you will have sciences flourish, you must observe David's military law, which was, That those which staid with the carriage should have equal part with those which were in the action; else will the carriages be ill attended. So readers in sciences are indeed the guardians of the stores and provisions of sciences, whence men in active courses are furnished, and therefore ought to have equal entertainment with them; otherwise if the fathers in sciences be of the weakest sort or be ill maintained,

Et patrum invalidi referent jejunia nati.

"And therefore inasmuch as most of the usages and orders of the universities were derived from more obscure times, it is the more requisite they be re-examined. In this kind I will give an instance or two, for example sake, of things that are the most obvious and familiar. The one is a matter, which though it be ancient and general, yet I hold to be an error; which is that scholars in universities come too soon and too unripe to logic and rhetoric, arts fitter for graduates than children and novices. For these two, rightly taken, are the gravest of sciences, being the arts of arts; the one for judgement, the other for ornament. And they be the rules and directions how to set forth and dispose matter: and therefore for minds empty and unfraught with matter, 
and which have not gathered that which Cicero calleth sylza and supellex, stuff and variety, to begin with those arts (as if one should learn to weigh, or to measure, or to paint the wind) doth work but this effect, that the wisdom of those arts, which is great and universal, is almost made contemptible, and is degenerate into childish sophistry and ridiculous affectation. And further, the untimely learning of them hath drawn on by consequence the superficial and unprofitable teaching and writing of them, as fitteth indeed to the capacity of children. Another is a lack I find in the exercises used in the universities, which do make too great a divorce between invention and memory. For their speeches are either premeditate, in verbis conceptis, where nothing is left to invention, or merely extemporal, where little is left to memory. Whereas in life and action there is least use of either of these, but rather of intermixtures of premeditation and invention, notes and memory. So as the exercise fitteth not the practice, nor the image the life; and it is ever a true rule in exercises, that they be framed as near as may be to the life of practice; for otherwise they do pervert the motions and faculties of the mind, and not prepare them. The truth whereof is not obscure, when scholars come to the practices of professions, or other actions of civil life; which when they set into, this want is soon found by themselves, and sooner by others."

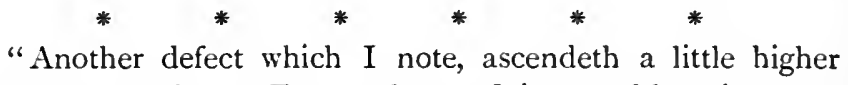
than the precedent. For as the proficience of learning consisteth much in the orders and institutions of universities in the same states and kingdoms, so it would be yet more advanced, if there were more intelligence mutual between the universities of Europe than now there is. We see there be many orders and foundations, which though they be divided under several sovereignties and territories, yet they take thenıselves to have a kind of contract, fraternity, and 
correspondence one with the other, insomuch as they have provincials and generals. And surely as nature createth brotherhood in families, and arts mechanical contract brotherhoods in communalities, and the anointment of God superinduceth a brotherhood in kings and bishops, so in like manner there cannot but be a fraternity in learning and illumination, relating to that paternity which is attributed to God, who is called the Father of illuminations or lights.

"The last defect which I will note is, that there hath not been, or very rarely been, any public designation of writers or inquirers concerning such parts of knowledge as may appear not to have been already sufficiently laboured or undertaken; unto which point it is an inducement to enter into a view and examination what parts of learning have been prosecuted, and what omitted. For the opinion of plenty is amongst the causes of want, and the great quantity of books maketh a show rather of superfluity than lack; which surcharge nevertheless is not to be remedied by making no more books, but by making more good books, which, as the serpent of Moses, mought devour the serpents of the enchanters ${ }^{1}$."

Elsewhere, speaking of universities, he says :

"As water, whether it be the dew of Heaven or the springs of the earth, doth scatter and lose itself in the ground, except it be collected into some receptacle where it may by union comfort and sustain itself; and for that cause the industry of man hath framed and made spring-heads, conduits, cisterns and pools; which men have accustomed likewise to beautify and adorn with accomplishments of magnificence and state as well as of use and necessity; so knowledge whether it descend from divine inspiration or spring from human sense, would soon perish and vanish to oblivion if it were not

1 Advancement of Learning, pp. 78-83 (Aldis Wright's Edition).

L. 
preserved in books ${ }^{1}$, traditions, conferences and places appointed as universities, colleges and schools for the receipt and comforting the same."

In the above passages Bacon has always in his eye the scientific encyclopaedia. And again in his Neri Atlantis Bacon returns to the consideration of the same subject,- "the amplification of the power and kingdom of mankind over the world"; and in the Address made to the traveller by the Father of Solomon's House we get some idea of the vastness of his academic scheme. He says :

"God bless thee, my son; I will give thee the greatest jewel I have. For I will impart unto thee, for the love of God and men, a relation of the true state of Solomon's House. Son, to make you know the true state of Solomon's House, I will keep this order. First, I will set forth unto you the end of our foundation. Secondly, the preparations and instruments we have for our works. Thirdly, the several employments and functions whereto our fellows are assigned. And fourthly, the ordinances and rites which we observe.

"The End of our Foundation is the knowledge of the Causes, and secret motions of things; and the enlarging of the bounds of Human Empire, to the effecting of all things possible."

He then proceeds to develope his conception of a great Institution devoted to Knowledge with a view always to the benefits thereby to be conferred on mankind; and it is no exaggeration to say that were all the Universities, Technical Colleges, Laboratories, Botanic and Zoological Gardens of Europe and America rolled into one, Bacon's great pansophic ideal would even then be only approximately attained.

1 Libraries, he says, are as the shrines where all the relics of the ancient saints, full of true virtue and that without delusion and imposture, are preserved and reposed. 
Writing on the education of Youth to Sir Henry Savill', he expounds his views as to the

\section{Pozver of Education.}

"But certain it is, whether it be believed or no, that as the most excellent of metals, gold, is of all other the most pliant and most enduring to be wrought; so of all living and breathing substances, the perfectest (Man) is the most susceptible of help, improvement, impression, and alteration. And not only in his body, but in his mind and spirit. And there again not only in his appetite and affection, but in his power of wit and reason."

"And as to the will of man, it is that which is most maniable and obedient; as that which admitteth most medicines to cure and alter it. The most sovereign of all is Religion, which is able to change and transform it in the deepest and most inward inclinations and motions. And next to that is Opinion and Apprehension; whether it be infused by tradition and institution, or wrought in by disputation and persuasion. And the third is example, which transformeth the will of man into the similitude of that which is much observant and familiar towards it. And the fourth is, when one affection is healed and corrected by another; as when cowardice is remedied by shame and dishonour, or sluggishness and backwardness by indignation and emulation; and so of the like. And lastly, when all these means, or any of them, have new framed or formed human will, then doth custom and habit corroborate and confirm all the rest. Therefore it is no marvel though this faculty of the mind of will and election, which inclineth affection and appetite, being but the inceptions and rudiments of will, may be so well governed and managed, because it admitteth access to

1 Vol. vir. p. 99 (Spedding's Edition). 
so divers remedies to be applied to it and to work upon it. The effects whereof are so many and so known as require no enumeration; but generally they do issue, as medicines do, into two kinds of cures; whereof the one is a just or true cure, and the other is called palliation." * * * *

\section{Method generally.}

Exercises. "That exercises are to be framed to the life; that is to say, to work ability in that kind, whereof a man in the course of actions shall have most use.

"The indirect and oblique exercises which do per partes and per consequentiam inable those faculties, which perhaps direct exercise at first, would but distort. And those have chiefly place where the faculty is weak not per se but per accidens. As if want of memory grow through lightness of wit and want of stayed attention, then the mathematics or the law helpeth; because they are things wherein if the mind once roam it cannot recover.

"Of the cautions of exercise; as to beware lest by evil doing, as all beginners do weakly, a man grow and be inveterate in an ill habit; and so take not the advantage of custom in perfection, but in confirming ill."

Order of Exercises. "The marshalling and sequel of sciences and practices: Logic and Rhetoric should be used to be read after Poesy, History, and Philosophy. First exercise to do things well and clean; after, promptly and readily."

In the Advancement of Learning ${ }^{-1}$ we find pertinent advice on the order and method in the study of Authors.

"There remain two appendices touching the tradition of knowledge, the one critical, the other pedantical. For all knowledge is either delivered by teachers, or attained by

${ }^{1}$ p. 18 I (Aldis Wright's Edition). 
men's proper endeavours; and therefore as the principal part of tradition of knowledge concerneth chiefly writing of books, so the relative part thereof concerneth reading of books; whereunto appertain incidently these considerations. The first is concerning the true correction and edition of authors; wherein nevertheless rash diligence hath done great prejudice. For these critics have often presumed that that which they understand not is false set down: as the priest that, where he found it written of S. Paul Demissus est per sportam, mended his book, and made it Demissus est per portam; because sporta was an hard word, and out of his reading: and surely their errors, though they be not so palpable and ridiculous, yet are of the same kind. And therefore, as it hath been wisely noted, the most corrected copies are commonly the least correct.

"The second is concerning the exposition and explication of authors, which resteth in annotations and commentaries: wherein it is over usual to blanch the obscure places and discourse upon the plain.

"The third is concerning the times, which in many cases give great light to true interpretations.

"The fourth is concerning some brief censure and judgment of the authors; that men thereby may take some election unto themselves what books to read.

"And the fifth is concerning the syntax and disposition of studies; that men may know in what order or pursuit to read.

"For pedantical knowledge, it containeth that difference of tradition which is proper for youth; whereunto appertain divers considerations of great fruit.

"As first, the timing and seasoning of knowledges; as with what to initiate them, and from what for a time to refrain them.

"Secondly, the consideration where to begin with the easiest, and so proceed to the more difficult; and in what 
courses to press the more difficult, and then to turn them to the more easy: for it is one method to practise swimming with bladders, and another to practise dancing with heavy shoes.

"A third is the application of learning according unto the propriety of the wits; for there is no defect in the faculties intellectual, but seemeth to have a proper cure contained in some studies: as, for example, if a child be bird-witted, that is, hath not the faculty of attention, the mathematics giveth a remedy thereunto; for in them, if the wit be caught away but a moment, one is new to begin. And as sciences have a propriety towards faculties for cure and help, so faculties or powers have a sympathy towards sciences for excellency or speedy profiting: and therefore it is an inquiry of great wisdom, what kinds of wits and natures are most apt and proper for what sciences.

"Fourthly, the ordering of exercises is matter of great consequence to hurt or help: for, as is well observed by Cicero, men in exercising their faculties, if they be not well advised, do exercise their faults and get ill habits as well as good; so as there is a great judgment to be had in the continuance and intermission of exercises. It were too long to particularize a number of other considerations of this nature, things but of mean appearance, but of singular efficacy. For as the wronging or cherishing of seeds or young plants is that that is most important to their thriving, and as it was noted that the first six kings being in truth as tutors of the state of Rome in the infancy thereof was the principal cause of the immense greatness of that state which followed, so the culture and manurance of minds in youth hath such a forcible (though unseen) operation, as hardly any length of time or contention of labour can countervail it afterwards."

In the above quotations we find the prognostication of many much-needed educational reforms. It was not, however, 
within Bacon's purpose to elaborate his views in their specific relation to the ordinary school. This, as regards Method at least, was left to Ratke.

Bacon represented not only the longing for a new Method and for the co-ordination of the sciences; but also the weariness of words and phrases and vain subtleties which had been gradually recovering their old place in spite of Rabelais, Montaigne, Ludovicus Vives, Erasmus, and Ascham. The poets, also, had been placing Nature before the minds of men in a new aspect. The Humanists, while unquestionably improving the aims and procedure of education, had been powerless to prevent the tendency to fall once more under the dominion of words, and to revert to mere gram. matical and rhetorical form. The realism of human life and thought, which constituted their raison d'être, had been unable to sustain itself as a principle of action, because, as we have seen, there was no school of method. It was the study of the realities of sense that was finally to place education on a scientific basis, and make reaction, as to method, impossible, at least in so far as thinkers were concerned.

The thought of any age determines the education of the age which is to succeed it. Education follows, it does not lead. The School and the Church alike march in the wake of science, philosophy, and political ideas. We see this illustrated in every epoch of human history, and in none so conspicuously as in the changes which occurred in the philosophy and education of ancient Rome during the lifetime of the elder Cato, and, in modern times, during the revival of letters and the subsequent rise of the Baconian induction. It is impossible, indeed, for any great movement of thought to find acceptance without its telling to some extent on every department of the body politic. Its influence on the ideas entertained as to the education of the rising generation must be, above all, distinct and emphatic. Every philosophi- 
cal writer on political science has recognized this, and has felt the vast significance of the educational system of a country both as an effect-the consequence of a revolution in thought-and as a cause, a moving force of incalculable power in the future life of a commonwealth. Thus it was that the Humanistic movement which preceded and accompanied the Reformation of religion shook to its centre the mediaeval school-system of Europe; and that subsequently the silent rise of the inductive spirit began to subvert its very foundations.

Bacon, though not himself a Realist in the modern and abused sense of that term, was the father of Realism. It was this side of his teaching which was greedily seized upon, and even exaggerated. Educational zeal now ran in this channel. The conviction of the Churches of the time, that one can make men what one pleases (by fair means or foul), was shared by the innovators. The method which could conquer all knowledge could also train the knowing powers and mould the whole man. By education, rightly conceived and rightly applied, the fervent successors of Bacon dreamed that they could manufacture men; and, in point of fact, the Jesuits had shown that a good deal could be done in this direction. The new enthusiasts failed to see that the genius of Protestantism is the genius of freedom, and that man refuses to be manufactured except on suicidal terms. He must first sacrifice that which is his distinctive title to manhood-his personality. 'That the prophets of educational Realism should have failed to see this is not to be laid at their door as a fault : it merely shows that they belonged to their own time and not to ours. They failed then, as some fail now, to understand man and his education, because they break with the past. The record of the past is with them, as it was with the Baconian realists, merely a record of blunders. The modern Humanist more wisely accepts it as the storehouse of the thoughts and life of human reason. In the life of Man 
each individual of the race best finds his own true life. This is modern Humanism-the Realism of thought. Let us not, however, confound Bacon with his bastard children in these days. He would not have acknowledged them.

Let us at the same time freely grant that it is to the Sense-realists of the earlier half of the seventeenth century that we owe the scientific foundations of educational method, and the only indication of the true line of answer to the complaints of the time. 


\section{CHAPTER XI.}

COMENIUS, THE SENSE-ENCYCLOPAEDIST AND FOUNDER OF METHOD ${ }^{1}$.

(d. 1671.$)$

IN March, 1892, three hundred years had elapsed since Comenius was born. The whole educational world was alive to the fact, and in Germany and America the day was widely celebrated, although forty years ago the name of Comenius was known only to an historical student here and there; and that, chiefly as associated with an illustrated school-book, the Orbis Pictus?

It is not universally true that writers of genuine original vein suffer neglect during their lifetime. Much depends on the position of social authority which they may hold, or on their power of fitting their fresh thought to the forms of expression current in their time. It cannot be said that Comenius, though an unsuccessful man, as all men of ideas are, failed to interest and attract his contemporaries : on the contrary, his two chief school-books were enormously popular; but he was

1 A memorial address for the three-hundredth anniversary of his birth. Delivered in Edinburgh and Birmingham.

The predecessor of Comenius was the Baconian Wolfgang Ratke, 157 I-1635.

2 A full account of Comenius's work on Education and a sufficient account of Ratke will be found in my Life of Comenius. 
scarcely dead when his name and reputation died also. That in him which was specially original was precisely that which most of all fell into oblivion. Bayle, in his "Dictionary" (1695), speaks of him in a depreciating way, though allowing that the Janua is an immortal (!) school-book; and nearly a hundred years afterward, Adelung, in his History of Human Folly, describes him as a man of weak and limited mind, and regards him as little more than a charlatan. Hallam passes him by, with a brief reference only to the Janua and the Orbis, characterizing him as a man of "some ingenuity but little judgment." No doubt much of this neglect of the old bishop was due to the fact that his ecclesiastical and pansophic writings were of only passing interest, and that his chief claim to permanent regard as an intellectual force lay in his contributions to the education of the young. Even in our own day a man who writes on education is regarded as, to some extent, a trifler, if not a fanatic, by historians and men of letters. The mere fact that he occupies himself with the education of the child-mind seems to stamp him as something of a child himself -in any case, as not worthy of notice, except by schoolmasters : and they avoid him. If Milton, the contemporary of Comenius, had written nothing but his Iractate on Education, he would have been long since forgotten, or, at most, known only to a few antiquaries, notwithstanding the literary excellence of portions of the famous essay. Roger Ascham has seldom been assigned his fit place as a stylist and a former of English prose; and this, because he wrote on education. Even many men of letters, whose business is the history of English literature, have not, I find, read his Schole. master, save in extracts, and, in like manner, classical experts know wonderfully little of Quintilian. Mulcaster's Positions has met with a like fate. And yet it is beyond all question that, had the subject on which these men wrote been the political backstairs gossip of "Mémoires pour servir," or tracings on monumental stones, or even the ways of bees or 
beetles, their importance as mere men of letters and as contributors to the enrichment of the substance, and refiners of the form, of the English tongue, would have been kept constantly in the eye of the literary public.

As a partial explanation of this neglect, it has to be noted that to write anything, having the aspect of novelty, on education and schools, is by implication to attack a large and powerful class, and to insure their hostility. This doubtless helps to consign the writers to forgetfulness. Even the venerable Comenius, when his life-work was approaching its close, was assailed at Amsterdam as an arch-enemy of schools and schoolmasters, and had to make a pathetic defence. "I can affirm," he says, "from the bottom of my heart, that these forty years my aim has been simple and unpretending; indifferent whether I teach or be taught, admonish or be admonished; willing to act the part of a teacher of teachers, if in anything it may be permitted to me to do so, and a disciple of disciples where progress may be possible. They say that I write against schools; nay, it is for schools that I speak and have spoken......Why, then, should any delight to molest me? Let me live in tranquillity as long as God wills me to be here."

To resent criticism of an institution, or a mode of administration, as if it were a personal attack on its administrators, is not confined to the teaching profession, but it certainly has been a more active characteristic of schoolmasters than of clergymen, lawyers, or physicians. Teachers, as a rule, do not wish to be disturbed by new ideas. Even Milton, though he shared with Comenius hatred of the traditionary methods, yet, just because he was himself a schoolmaster, suffers from this narrow pedagogic spirit, and declines, in his letter to Hartlib, to have anything to do with new-fangled notions. "To search what many modern Januas and Didactics, more than ever I shall read, have projected, my inclination leads me not." It is true that he also says, "What I have benefited herein among old renowned authors I shall 
spare." Who the "renowned authors" may have been, however, he does not say ; nor does his treatise give any indication that he ever read any of them, although we may, perhaps, not err in presuming that Quintilian, at least, was not unknown to him. Doubtless this peculiar attitude of the scholastic mind is largely due to the position of authority in which teachers are placed when yet young and unformed. They succeed to a certain traditionary way of doing things; a few years' practice habituates them to it, and this habit combines with the almost despotic position in which they are placed to produce a selfconviction of finality. They repeat themselves from day to day and call it experience. It is unreasonable, accordingly, to blame teachers for their attitude to the science, history, and criticism of their art. The causes are obvious : to understand is to sympathise. And it is vain, I think, to expect this attitude to be altered until all intending schoolmasters are required, before they begin their work, to study the theory and history of education. The academic study of their science and art, such as is now found at many universities in America, Germany, and elsewhere, will convey to the young aspirant the best tradition, while stimulating to thought on his own account. If he begins to think about the principles and aims of his profession when still young, he will, in the great majority of cases, continue to think when engrossed with the practical work of the school.

Comenius did not flash on the world unheralded. Perhaps no man ever stood forth as the representative of an intellectual or moral movement by organizing its essential characteristics in a coherent statement, without owing much to his predecessors. Aristotle had his Plato, and Newton his Kepler, and Bacon had many men working for the inductive gospel before he formulated the Novum Organum. So with Comenius. To begin with, the Reformation movement had stirred questions which went far beyond the limits which it had originally prescribed for itself, and in no department did it 


\section{COMENIUS, THE SENSE-ENCYCLOPAEDIST}

more directly assail old conceptions than in that of education. It would be out of place here to show how this was a necessary consequence of the Reformation principle, and it would only irritate a reader to have the words of Luther and others quoted for the hundredth time. The questions, however, of zinom to teach and what to teach, naturally first occupied the field of vision, to the exclusion of the more fundamental question, how to teach. Ascham and Sturm certainly wrote on the "how," but their "how" was limited to the teaching of the Latin language and literature. It is surprising to find how many books treated of the work of schools before Comenius came on the field. Comenius, accordingly, had many forerunners; but this does not justify us in exaggerating what he owed to them, by way of detracting from his greatness and originality. No one is more open and candid on the subject than is Comenius himself. He names the books he had read, always in the sincere hope of finding what he wanted. He had no desire to originate. I doubt if there ever was a man who devoted himself to labour for his fellow-men so ardently as Comenius did, in the field of religion, intellectual progress, and education, who was less of an egotist. He worked and wrote in the most single-hearted spirit. Much, very much, of the work he did for education was, in truth, done unwillingly and from a pure sense of duty. His main intellectual interest was his pansophy, the co-ordination of all knowledge with a view to the advance of humanity and the conciliation of religious parties. All that he conceived and did was conceived and done for the "glory of God," and to advance Christian unity and a rational Christian civilization on a Protestant basis. An irenicon was the necessity of the times, and it was the dream of Comenius, as it was of Vives, Casaubon, and Grotius. Thus, in many essential respects he was the European popularizer of Bacon, and he was perhaps also the first evangelical Broad Churchman among Protestants. He was constantly, however, setting aside his more ambitious schemes to do the educational work that 
lay to his hand; and this he called following the leadings of Providence.

The three most important of the precursors of Comenius were Ludovicus Vives the Spaniard, Bacon the Englishman, and Ratke the Holsteiner.

Vives was born in $\mathbf{1 4 9 2}$, at Valencia, exactly one hundred years before Comenius; Bacon was born in 1561 ; and Ratke in $157 \mathrm{I}$, twenty-one years before Comenius. Rabelais and Montaigne seem to have been unknown to Comenius. Of Vives, Comenius himself says that he knew better where the fault in schools lay than the nature of the remedy; and yet he, like Bacon, owed more to Vives than he imagined--if not in the sphere of education, at least in his whole cast of thought, including his pansophic ideal. For Vives was an encyclopaedist in his range of intellectual activity, an enemy of mere authority, directing attention away from the barren dialectic of the schools to the silent study of nature. Like Comenius, too, he was one of those who were always hoping to find some basis of ecclesiastical and civil unity which might conciliate the distractions of the time. $\mathrm{He}$ is sometimes called a Humanist, sometimes a Realist. The truth is, that after giving promise of future distinction as a schoolman, he grew out of the scholastic philosophy, and became, in relation to the general current of thought, a Humanist, but without falling into the idolatry of style which characterized the leaders of that movement. In relation to education and the school, he was a Realist only in so far as he included in his course of education realistic subjects. In his book, De Tradendis Disciplinis, he treats of the education of the child from infancy, keeping in view always the moral aim of all instruction. What he says is always characterized by good sense; but to us nowadays his rules and recommendations are commonplaces. In his book on the education of women, for which he has been extolled as a reformer, it is the morals, manners, and domestic training of women, along with instruction in reading and 
writing, that he speaks of; beyond this, nothing. The instruction of boys meant, with Vives, as with everybody in those days, Latin chiefly ; and he gives eight or nine years to the acquisition of this language ${ }^{1}$. Into the school curriculum, however, he would introduce Greek, history, geography, and nature-knowledge. But he does not seem to have had any idea of a curriculum through which, with a view to mindculture generally, all boys should be carried. His remarks are generally pertinent and sagacious, and it is believed that the Jesuit teachers learned much from him; but to the specific subject of method, in our modern sense, he does not seem to have made any contribution of value. There is, I suspect, little in Vives that may not be found in Quintilian and Plutarch. The severe discipline of the time, and the want of lightness and variety in school-work, are condemned by him, but in this and in other respects he only shares his opinion with many writers. This slight sketch of the teaching of Vives will suffice to show that Comenius may have owed to him suggestion and stimulus, but nothing more.

The educational activity of men like Vives supports the view set forth in the beginning of this book, viz. that it is impossible clearly to apprehend the history of education from the close of the Middle Ages down to this century, unless we distinctly recognize two lines of thought which run side by side in their beginning, but soon cross each other-the theological and the literary. The Renaissance had many aspects; in its purely educational aims it was an attempt to rouse men from dogmatic slumber, and to bring them face to face once more with nature and life as that was interpreted

1 The latter half of the $15^{\text {th }}$ century was full of complaints as to the time spent in learning Latin and full also of short ways, but no one then or for $\mathbf{r} 50$ years after doubted its absolute necessity. John Sturm states the case thus :"Romanus sermo per omnes nationes et populos et regna commeat. Neque usquam gentium venias ubi non Latinum hospitem invenias qui viam proficiscenti monstret. Adeó linguam hanc hospitalem esse voluit Deus quam laté terrarum orbis patet, hominibus." 
in the great literatures of Greece and Rome. The Reformation of religion was only a part of the movement, and, till Luther's time, a subordinate part. When the Lutheran movement, however, fairly took hold of men's minds, literature and pure Humanism found a potent rival in theology and the new ideal of justification, saving grace, and personal piety. "By faith are ye saved"-not by literature. Unquestionably, the more enlightened reformers, and notably Luther and Melanchthon, accepted literature and a genial view of human life. But the literary and artistic interest was not dominant with them, as with Erasmus. Faith, justification in the sight of God, and morality as fruit of faith, constituted the chief end of man, and consequently of the education of the young. But the reformed faith did not, as yet, wholly break with Humanism, as Christianity had done before the fifth century.

After Luther and Sturm and Ascham, however, the paramount interest began to obscure the less important. The career of Casaubon illustrates this. Though much had been done to improve the curriculum of schools, the literary enthusiasm had exhausted itself, and there was unquestionably a relapse into the old formalism. The Catholic reaction, also, called many minds away to the main issue of modern civilization-personality versus organized spiritual despotism. Then came on the scene a new educational force-the potent ideas of Realism as represented by Bacon. Nature was to be studied at first hand; and studied by silent and faithful observation. This study had more than a mere theoretical interest. The observation of nature and of its teachings was to accomplish great things for the improvement of the social and industrial conditions of human life. In a letter addressed by Bacon to Casaubon, these words are used : "The contemplations I have in view are those which may bring about the better ordering of man's life, with all its turmoil ${ }^{1}$." Nature, in

1 Footnote in Pattison's Life of Casaubon, p. 335. The letter was never sent. 
short, was to be used as a gift of God to man. There was nothing in this nearly so dangerous to the Protestant theological conception of life as pure Humanism was, which in some of its manifestations had little to distinguish it from a cultured paganism; and this the Christian Church had always feared as its chief enemy, until in the middle of the sixteenth century the Jesuits suborned it. There was nothing, in truth, to prevent the whole-hearted union of Realism and a liberal reformed theology; but in their relations to Realism the Jesuits, who had already captured Humanism and subordinated it to the Church, had to reconsider their ways ; and are still reconsidering them. Science and the scientific spirit gave them their death-blow, though it is true they are long of dying.

Now, Ratke and Comenius were the apostolic missionaries of the specific Baconian realistic movement in the field of education. They adopted the saying that "there was nothing in the understanding which had not first been in sense"; but neither they nor any of their contemporaries saw the farreaching and fatal philosophical and theological effects of such a doctrine. The maxim was used only to establish the necessity of founding all instruction on sense, and on all the senses, and the importance of cultivating the powers of observation. "Iive we not in the garden of Nature, as well as those who have gone before us?..... Why, then, learn the works of Nature otherwise than through our senses? Why not substitute for dead books the living book of Nature?" The philosophical consequences, I say, of the celebrated dictum as to intellect and sense could not occur to such men as Comenius ; for, in his crude psychology, there was, quite apart from the mere understanding, the "soul," and the spiritual life of the soul in God.

Bacon's interest lay in the sphere of the higher education. $\mathrm{He}$ was a pansophist, and his ambition was to see a visible organization of science, in the form of a great State-supported academy of investigation and teaching. In this respect 
Comenius directly affiliates himself to Bacon. All that Comenius did in this department of his activity derives itself from the Englishman. The Advancement of Learning and the Nere Atlantis were the teachers of Comenius. The same magnificent conception lay at the foundation of the "Institut National," projected by the French revolutionaries in I 795. "Finally, we propose to you to create a National Institute," they said to the Government, "able in its several parts to give every branch of public instruction and collectively human knowledge carried to its highest point : everything which men know must be taught there to its highest perfection: every man must be able to learn there how to do what any man of any country, aglow with the fire of genius, has done, and is able still to do. This establishment must honour, not France only, but the whole human race, astonishing it by the spectacle of its power and the development of its strength ${ }^{1} . "$ The names of the first members of the Institute were those of men capable of doing the work expected of them-Lagrange, Laplace, Legendre, Cuvier, Volney, Sainte Pierre, Lakanal, Chénier, Lebrun, and Fontanes. It is a curious fact that the Long Parliament (also a revolutionary Parliament) contemplated, in $164 \mathrm{r}$, handing over Chelsea College to carry out the pansophic views of Comenius, thus anticipating the action of the French Republic by one hundred and fifty years. The Baconian, Comenian, and revolutionary ideas have now been, in some places, almost realized; and, in so far as they are not realized, they still enter into the dreams of university reformers. It is of importance to insist on this, because it has been customary to look on the fervent old bishop as a visionary, whereas he was the most practical of men-only living a few centuries too soon.

The advocacy of pansophy and realism did not exhaust the powers of Comenius. He was an ardent worker, as I have

1 Quoted from a paper by Mr. Jamson Smith, Birmingham. 


\section{48 COMENIUS, THE SENSE-ENCYCLOPAEDIST}

indicated above, in the cause of a Protestant union, based on the vital and essential interests of Christianity. His Unum Necessarium had this for its aim. The fanatical divisions of Protestantism had been the Jesuits' opportunity. Being an unorganized mass, they had been swept back by the serried ranks of Loyola. Protestantism was in a critical position.

It has been sometimes said that Comenius owed much to Valentine Andreä, his senior by four years. This remarkable man, born at Herrenburg in 1586 , was distinguished for his learning, energy, and originality, and stood eminent among his contemporaries. Of him Herder said that he "blossomed as a rose among thorns." He was a man of poetic and ideal character, and yet, like Comenius, in the highest degree practical. Like other educational reformers, he attacked the mechanical character of grammar-school instruction, and the equally mechanical character of the people's schools, and of the instruction of children in the Catechism. He desiderated a better method in both the primary and secondary schools, and the substitution of an evangelical spirit for the heathenism and arid curriculum of the latter. His disgust of the narrow range of school instruction made him lean to realistic studies and hail with enthusiasm Comenius's Didactica. Realist as he was, however, education by means of language, and education by means of things, was subordinated to the religious aim-"omnis spiritus cedat Christo." His educational ideas are contained in his Reipublicae Christianopolitanae Descriptio, I6I9. A book published in his youth, called Idea Bonae Institutionis, is lost. The dates of these books show that he had anticipated Comenius as an educational writer; but there is no evidence that Comenius owed anything to him which he did not himself already ascribe to the general influence of Vives. Impulse, sympathy, and encouragement he found, doubtless, in Andreä's strongly expressed views, as he did in the personal recognition and encouragement which Andreä himself generously extended to him by letter; but this was all. 
Within a few years after the publication of the Advancement of Learning (1605), we find Ratke, the Holsteiner, formulating the new ideas in the interest of education and attracting the attention of the princes and universities of Northern Europe. Although it is true that Ratke failed to answer Comenius's letter of inquiry, there can be no doubt that Ratke anticipated him in all his general principles of method. To him, and not to Vives or Andreä, Comenius was directly indebted. There was, perhaps, more of the light of originality in Ratke than in Comenius.

To Bateus, the Irish Jesuit, who died at Madrid in 1614, Comenius was, in an indirect way, also indebted, in so far as the Jesuit's Janua showed the possibility of bringing together a vast number of vocables in a school-book, and also in so far as it showed him what to avoid. He called it a "Noah's Ark for Words." To Professor Lubinus of Rostock, again, who died in 1621 , Comenius certainly owed the first idea of the Orbis Pictus.

I think I have now exhausted the external sources of Comenius's inspiration, and the result is this : In respect of his philosophy, and of the materials which should enter into the education of man, Comenius was a disciple of Bacon, of whom he speaks as "the noble Verulam, who has given us the true key of nature"; in respect of the fundamental conception of method as determined by the inductive process of mind, and many of the rules of method, he was indebted directly to Ratke and only indirectly to Bacon; and to Lubinus he owed the suggestion of the Orbis Pictus. But in the wide reach of his educational conceptions, in the development of the whole subject of method, and in his mode of procedure in discovering it, and expounding it, Comenius was wholly original.

Let us now briefly consider the leading characteristics of Comenius as an educationalist, bearing in mind, the while, that the education of his age consisted of reading, writing, the 


\section{COMENIUS, THE SENSE-ENCYCLOPAEDIST}

Catechism badly taught, and Latin-nothing but Latin, with here and there, but chiefly in the universities, Greek and scholastic logic-even reading and writing being for the few, and further education only for the select among those few.

I. Comenius held that every human being should be educated, simply because he was a human being. This is nothing new to us, but it was an immense step in advance of previous thinkers. Luther and his friends desired to educate the young because they had souls to be saved; Comenius, simply because they were human beings.

2. In perfect consistency with this fundamental view, Comenius advocated pansophy in the school, for only by an encyclopaedic training could we build up the whole fabric of the human mind. We must begin by instructing in the elements of all things, for our final aim has need of them all, that aim being threefold:--First, knowledge universal, including knowledge of oneself; second, virtue; and third, religion. There is involved in the first portion of the threefold end a thoroughgoing encyclopaedism. The work to be done in the school has for its ultimate aim pansophy, and is entirely governed and suggested by the pansophic ideal of man and society. Universal knowledge is to be organized, and all must share in it.

3. Knowledge must be expressed in the vernacular of each nation, for it is a human possession, and not the possession of any one individual or class. This also was logically involved in his fundamental conception. "We desire and protest," he says in the Prodromus, "that studies of wisdom be no longer committed to Latin alone, and kept shut up in the schools, as has hitherto been done, to the greatest contempt and injury of the people at large and of the popular tongues. Let all things be delivered to each nation in its own speech." This was clearly a necessary deduction from his principle that every human being had, as such, a right to 
education. All knowledge existed for the bettering of man's condition and elevating him as a rational being. Nature is God's work, and is an enemy of man only in so far as he does not know it. He must, then, be taught to know nature and to know himself. Why? That he may rule nature; and also rule himself, which is virtue. The more comprehensive the knowledge, the wiser is the ordinary life of man, and the more assured, consequently, is his virtue. Nay, religion, as well as virtue, rests on a knowledge of nature. Man's nature and external nature presented themselves to the mind of Comenius as a fundamental harmony. In this harmony was visible the goodness of God : man's business was to find it and then to refer all things to God, and lead a life in nature and society as with Him. So Milton held that we could not arrive at a "knowledge of God and things invisible, save by conning over the visible inferior creature"; and Picus of Mirandola identified the law of nature with the utterance of "our Lord Himself."

4. If encyclopaedic knowledge is to be acquired, even in its elements, we must take care that every one begins early, i.e. in the infant school. Comenius was the originator of the idea of the infant school-the "school of the mother's lap," as he calls it; and there is little in Pestalozzi and Fröbel which is not in Comenius, though not in him fully developed. Very simple instruction is to be given, only such as infant minds can assimilate; but, however simple it may be, it must be widereaching as nature itself. It must be a foundation broad enough to sustain, in the long run, the weight of the pansophic temple.

5. How this broad foundation was to be laid, and a building erected on it, was the question of questions, for it was the question of method, and is the problem solved in the Great Didactic-Comenius's central work. Ratke's leading positions were that all procedure in education was to be from particulars to generals, and all, consequently, by observation and experiment. The Baconian philosophy showed that thus. we acquired knowledge, and accordingly thus must we impart 
knowledge. For with Ratke, as with Comenius, it was always giving and imparting, but now no longer a mere storing of memory, but all according to a method such that the teaching of one thing should be the teaching to reason on all things. Comenius seized on the same conception, and wrote, as I have said above, to Ratke for fuller information; but his letter remained unanswered, and he had to think out the problem for himself ${ }^{1}$. And just at that critical point, his philosophy of the world and of man's life, and the harmonious relation of the two, came to his aid. The world was not a mechanical construction, but dynamical. It was the wisdom of God making itself manifest; and, as regarded man, God's purpose was to bring him back to himself through nature and life. Let nature and man, then, be conceived as order and law, with a purpose. But if this were so, there must be some way of building up knowledge, virtue, and religion in the mind of man, so as to make him what he is intended to be-an image of his Creator. There must be order and law here as well as elsewhere. The larger cosmical conception suggested the way, for what was true of the whole must be true of the parts. Each individual thing, no less than the cosmic whole, was dynamical; each thing was an organism growing from seed to flower and fruit. In fact, the biological process was the mind-process. In his Prodromus, p. 40, he says, "After many workings and tossings of my thought, by reducing everything to the immovable laws of nature, I lighted upon my Didactica Magna, which shows the art of easily and solidly teaching all men all things."

6. Having already determined the end of education and the materials to be used, it was now clear to Comenius that the building up of the mind by means of these materials must be an organic process. In nature, then, he must find the clue to the method of education-in the chick, and in the seed of the

I Except in so far as he may have read some of Ratke's writings. 
plant, and in their gradual development. The mode of procedure in finding principles and rules was analogical, or, as he calls it, syncretic. The science of nature was then in its infancy, and Comenius could work only on such knowledge as he had-sometimes mistaken, always inadequate. His firm conviction, however, in the harmony of things sustained him. The result was that many of his illustrations were fanciful, and some of his rules of method strained. Yet in the main he was right. In spite of many defects, we have from him the only thoroughgoing treatise on educational method that has yet appeared in the history of the world.

7. Comenius reformed language-teaching, and began a new era in text-books. He had been met at once by a great difficulty in the practical working out of his theory. The curriculum of the schools was substantially Latin, and in Latin. His theory of the building up of the human mind demanded realia. Hence he advocated teaching of and in the vernacular: the vernacular first, and then Latin. When Latin had to be faced, his principles led to the Janua and the Orbis Pictus, which latter is an illustrated real-encyclopaedia for the young. All the words necessary for Latin intercourse must be acquired as soon and as easily as possible. But things had also to be taught, of which words are but the symbols. Words, then, must be taught with and through things. Language and reality must go hand in hand. The building up of a knowledge of things was the true building up of minds. Words being but the symbols of things were best acquired along with the things of which they are the symbols. Thus we kill two birds with one stone. Then, the true process of mind was the inductive. Accordingly, the universal was to be reached through the particular. Hence the multitude of facts in his school-books, which were to be the basis of future generalization and reasoning. As with things, so with language; the elaborate abstractions of Latin grammar are obstructive. Reading and grammar must go together, and grammar itself must be 


\section{54 COMENIUS, THE SENSE-ENCYCLOPAEDIST}

simplified, and dictionaries too. Hence his graded grammars and dictionaries, that the time spent over Latin might be shorter, and progress more pleasant for the pupil. "If so much time is to be spent on language alone," he says, "when is the boy to know about things? when will he learn philosophy, when religion, and so forth? He will continue his life in preparing for life." Again, all was to be graduated, and adapted to the boy's age.

8. As to school discipline, Comenius was far ahead of his own time, and even of ours. The seeds of knowledge, of virtue, and of piety were, to begin with, already in the child. Only wise culture was needed to make them spring into life and grow to maturity, just as with plants. Coercion was thus entirely out of place; method superseded it, although he admitted that corporal chastisement was sometimes necessary for moral offences.

\section{Omnia sponte fluant: absit violentia rebus.}

9. As to the education of girls, Comenius was not only more thoroughgoing than Vives and Erasmus, but two hundred and fifty years in advance of other men. I take Professor Masson's translation of Comenius's utterance on this subject ${ }^{1}$ :$\checkmark$ "Nor, to say something particularly on this subject, can any sufficient reason be given why the weaker sex should be wholly shut out from liberal studies, whether in the native tongue or in Latin. For equally are they God's image; equally are they partakers of grace, and of the kingdom to come; equally are they furnished with minds agile and capable of wisdom, yea, often beyond our sex; equally to them is there a possibility of attaining high distinction, inasmuch as they have often been employed by God Himself for the government of peoples, the bestowing of wholesome counsels on kings and princes, the science of medicine, and other things useful to the human race, nay, even the prophetical office, and the rattling 
reprimand of priests and bishops. Why, then, should we admit them to the alphabet, but afterwards debar them from books? Do we fear their rashness? The more we occupy their thoughts, the less room will there be in them for waywardness, which springs generally from vacuity of mind." $v$

Now it is an easy matter to pick holes in Comenius, whether we regard him as a mystic theologian, a pansophic philosopher, an enthusiastic humanitarian, or an educational reformer. I leave this task to those who care to do it. Assuredly no schoolboy in Europe or America, who understands the nature of the old bishop's work, would do it, even if he had the intellectual power; and this, perhaps, is the highest tribute to the services which Comenius rendered. I confine myself to pointing out the defects which lapse of time and the accumulation of experience have taught us to be defects; for it is the logic of events that teaches us the wisdom we call our own.

The Baconian dictum, "Knowledge is power," is false, or, at least, fallacious. Power lies in ideas and ideals, and a vigorous intelligence behind them. This, Comenius, and with him modern sensationalists, did not see. The mind is not built up by universal knowledge, but by its own native energy and activity in using a little well. Discipline of mind is of more importance than the stocking of mind with multifarious knowledges. "Knowledge comes, but wisdom lingers." We can now scarcely understand that men should seriously maintain that we could form men by knowledge; but it was an earnest conviction. "The mind is the man and the knowledge of the mind. A man is but what he knoweth," says Bacon. This being so, the conception of the school as an officina humanitatis is a logical enough consequence.

Further, the pansophic basis in elementary education is to be advocated only in a restricted sense. Children begin with close and narrow interests and widen as they grow older. 
Literature, which, as artistic expression, includes art, is the most potent of all instruments in the hands of the educator, whether we have regard to intellectual growth, or to the moral and religious life. Comenius, however, had not the remotest conception of the aesthetic and literary, and in this respect is like Locke. His own Latin prose is hard and poor and negligent. So far, he is certainly an anti-humanist. But he is not an anti-humanist in his conception of the ends of education as moral and religious ends, but only in the narrower meaning of Humanism that characterized the first period of the Renaissance, when art and literary form were all in all. $\mathrm{He}$ grew up in the latter half of the second humanistic period, when textual criticism and erudition prevailed, and when men's minds were too much agitated by the success of the Catholic reaction to find time to pick phrases and polish lines. The second epoch, even - that of Scaliger, Casaubon, and Buchanan -was already passing away.

Further, his fanua as a book for learning Latin, is, it must be confessed, a failure.

Finally, Comenius had no psychology to speak of, and thus he was compelled to rely on the frail support of analogy for the grounding of his principles.

Neither in his philosophy nor his erudition was Comenius profound. Joseph Scaliger and Casaubon, of the immediately preceding generation, would have had none of him: Spinoza, writing his Ethica round the street-corner while Comenius was carrying his cumbrous works through the press, would have smiled at his too energetic faith. The theologians, so much in evidence in the beginning of the seventeenth century, would have deplored his vagueness and want of dogmatic system. But, in truth, he was a better theologian than any of them-Swiss Calvinist, Roman Jesuit, or Dutch Arminian; while his moral enthusiasm and educational insight almost raised him to the rank of genius. The present and the future so engrossed him that he had no time to overweight his mind 
by accumulating the written records of the past. He lived at a time when men of intellect were divided into two classes, those who looked back and those who looked forward; he was essentially a modern, and at once put his hand to the work that was most urgent in the interests of Europe, viz. an irenicon, scientific organization, and education.

And yet, whatever his shortcomings, Comenius remains for us the most earnest and simple-hearted worker for the education of the people, and the most penetrating writer on method whom the world has ever seen - in fact, the founder of method. The more we study the subject of education in connexion with the various influences at work in the beginning of the seventeenth century, whether we take its large national, or narrower scholastic, aspects, the more clearly do we see that the simple-minded, much-enduring, and self-denying Moravian bishop, so long forgotten, stands out as a prominent figure even in general European history, and as quite the most eminent in the history of European education. $\mathrm{He}$ is still a living influence, and a power that will remain. When we read the record of his days, we are amazed at the persistency of his self-imposed labours in the midst of uncertain fortunes: of him it may be truly said that he "linked month with month in long-drawn chain of knitted purport."

"I thank God," he said, after a toilsome and disappointing pilgrimage of fourscore years, "that I have been a man of aspirations." But it is not as a man of aspirations alone that we honour him to-day, but as a man who laboured for us as few men have laboured; who, in all the chances and changes of his troubled life, was a unique and touching example of the Christian graces of faith, hope, and love, and who has bequeathed to us, as the solid fruit of his aspirations, the Great Didactic-a possession which the educational world, at least, "will not willingly let die."

NoTE.-There can be no doubt that Mulcaster (died 16II ?) anticipated much of both Ratke and Comenius, but there is no 
evidence that he was known to them. Mr Quick says in his Educational Biographies, "The latest advances in pedagogy have established : (I) That the end and aim of education is to develop the faculties of mind and body. (2) That all teaching processes should be carefully adapted to the mental constitution of the learner. (3) That the first stage of learning is of universal importance, and requires a very high degree of skill in the teacher. (4) That the brain of children, especially clever children, should not be subjected to pressure. (5) That childhood should not be spent in learning foreign languages, but that its language should be the mothertongue, and its exercises should include handiwork, especially drawing. (6) That girls' education should be cared for no less than boys'. (7) 'That the only hope of improving our schools lies in the training of teachers." These were all advocated by Mulcaster. 


\title{
CHAPTER XII.
}

\section{JOHN MILTON', THE CLASSICAL ENCYCLOPAEDIST.}

\author{
(d. 1674.)
}

WHEN we reflect that Milton was not only a Great Poet-one of the greatest-but also the most learned and accomplished man of his time, we naturally approach his Tractate with profound respect and in the anticipation of much instruction. Our expectations, it must be confessed, are at first disappointed. For we are entitled to expect not only philosophic grasp but also practical guidance from a man of genius who happened to be also himself a teacher and for a long time kept a boys' school in Aldersgate Street. On a closer acquaintance with the book, however, we find much more in it than is obvious in a first reading.

Rabelais and Montaigne had first moved in the direction of the realistic in education, but by the real, Montaigne meant studying what was said by eminent writers as opposed to mere words and grammatical rules. $\mathrm{He}$ held that the languages might be taught as they were taught to himself, conversationally, and that the true end of education was not learning, in the linguistic, or any other sense; but Wisdom. Rabelais advocated,

1 Born 1608: died 1674. Tractate on Education, published in 1644 , and a second edition 1673 at the end of the second edition of the minor poems. 
in addition to this, realistic instruction in its usual sense. Milton also, nearly roo years after, wrote in the same sense, but he was largely influenced by the educational movements which had preceded him under Ratke and which were even then represented by Comenius. He directly refers indeed to Comenius's works in a somewhat sneering way in the beginning of his Tractate. "To tell you," he says, "what I have benefited herein among old renowned authors, I shall spare; and to search what many modern Januas and Didactics, more than ever I shall read, have projected, my inclination leads me not." The reference is manifestly to Comenius's Janua Linguarum Reserata and to the Magna Didactica, in which Comenius lays down his principles; or it may be to the Didactics of Ratke. But no man, not even a Milton, however he may ignore the originators of ideas, can keep himself outside the influence of the ideas themselves, if they are in the air.

Let us first of all bear in mind that Milton's Treatise is only a very condensed and brief statement, written at the request of his friend Hartlib, the devoted follower of Comenius, and that it reads more like a summary of opinions to be afterwards elaborated than a complete treatise. It is because of the almost negligent structure of the Essay and the condensed and pregnant character of the style - "a few observations which have flower'd off and are as it were the burnishing of many studious and contemplative years"-that it demands close attention if it is to be thoroughly appreciated.

Milton was to a certain modified extent a Realist and Encyclopaedist like Comenius, but in essential respects different. For he was a realist who sought the study of reality, in so far as realism entered into his system, in the ancients, whereas Comenius sought for the study of reality as modern science presented it, including the ancients or abridgments of their works, only in so far as they were necessary and accessory. In another essential respect Milton differed from Comenius. 
He had not in view the education of the people as a whole. He thought only of the few- "our nobler and our gentle youth" - - those who had time for prolonged study.

Both writers, however, were alike in disregarding mere words-language and literary expression-as in themselves containing the elements of knowledge and discipline during the juvenile or primary period of education.

Oratory, poetry, all art in language, were certainly recognized by both (as they are by all realists whom it is worth our while to consider), but only as the ornament and finish of education and as belonging to the period of adolescence. The peculiar discipline of mind given by the comparison of a modern with an ancient tongue is not even alluded to by either Milton or Comenius. This was largely due to the prevalent method or no-method of teaching which justified Milton in calling the studies of schools and universities "an asinine feast of sow-thistles and brambles," and again, "meer words or such things chiefly as were better unlearnt."

\section{The End of Education.}

Milton's first proposition is thus laid down :

"The end then of Learning is to repair the ruines of our first Parents by regaining to know God aright, and out of that knowledge to love him, to imitate him, to be like him, as we may the meerest by possessing our souls of true virtue, which being united to the heavenly grace of faith makes up the highest perfection. But because our understanding cannot in this body found it self but on sensible things, nor arrive so clearly to the knowledge of God and things invisible, as by orderly conning over the visible and inferior creature, the same method is necessarily to be follow'd in all discreet teaching. And seeing every Nation affords not experience and tradition enough for all kind of Learning, therefore we are chiefly taught the Languages of those people who have at any time 


\section{JOHN MILTON, THE CLASSICAL ENCYCLOPAEDIST}

been most industrious after Wisdom; so that Language is but the Instrument conveying to us things usefull to be known. And though a Linguist should pride himself to have all the Tongues that Babel cleft the world into, yet, if he have not studied the solid things in them as well as the Words \& Lexicons, he were nothing so much to be esteem'd a learned man, as any Yeoman or Tradesman competently wise in his Mother Dialect only."

Now in this passage we have several propositions which it is worth our while to disentangle that we may clearly comprehend Milton's view of the End of Education.

I. The aim of Education is the knowledge of God and likeness to God.

2. Likeness to God we attain by possessing our souls of true Virtue and by the Heavenly Grace of Faith.

3. Knozvledge of God we attain by the study of the visible things of God.

4. Teaching, then, has for its aim this knowledge.

5. Language is merely an instrument or vehicle for the knowledge of things.

6. The knowledge of all the languages in the world, without a knowledge of the solid things regarding which they treat, leaves a man less "learned" than any farmer or tradesman who knows only his own vernacular, but, in and through that, has a competent knowledge of things.

Milton also tells us in another part of his Essay that he considers that to be "a compleat and generous education which fits a man to perform justly, skilfully and magnanimously all the offices, both private and public, of Peace and War." With this large and noble aim all will heartily concur. But we cannot pass without remark the assumption contained in the larger statement of the aim of education. We do not admit that the knowledge of language is not a knowledge of things. We would, on the contrary, maintain that language, apart from the general argumentum of a writer, is a thing-a thing intel- 
lectual and a thing moral. And further in these days, when language extends itself into the science of comparative philology, it is also a thing scientific.

I shall not dwell on this however, because I wish rather to expound Milton's views than to criticize them. It is enough that I emphasize the above aspect of Milton's doctrine, as it is with him fundamental and explains much that follows.

Too much time, he says, is spent in acquiring a knowledge of Greek and Latin. We spend seven or eight years in acquiring what might be acquired in one-especially if we would stop the absurd practice of the "forcing the empty wits of children to write Theams, Verses and Orations, which are the acts of ripest judgment and the final work of a head fill'd by long reading and observing." Another objection to the practice is that the boys are under the necessity of "using such language as they have, thus barbarizing against the Latin and Greek Idiom with their untutored Anglicisms odious to be read."

We may now pass from the general aim of education to the detail of Milton's scheme, merely premising that he had in view boys from 12 to 2 I years of age, that is to say, the secondary and university periods of instruction.

\section{The Materials and Order of Education.}

\section{Secondary School Stage.}

Milton's opinion is that after the boys have acquired the accidence and the "chief and necessary rules" they should have "some chosen short book lessoned thoroughly to them," with a view to praxis of the accidence and syntax. Arithmetic and Geometry are to be learned at "some other hour of the day, even playing as the old manner was."

The pupils, now we may presume thirteen years old, were next immediately to proceed to the study of things in Latin and 
Greek authors, and they would thus "bring the whole language quickly into their power." This he considered to be "the most rational and most profitable way of learning languages and whereby we may best hope to give account to God of our youth spent herein."

The things to be studied first and for long are sensible things and not abstractions. We learn from Phillips, who was a pupil of Milton's at Aldersgate Street, the names of the books which Milton made use of in teaching with a view to give instruction at once in language through things, and things through language:

The work of Cato Major, De Re Rustica-the only work of Cato's which has come down to us.

Columella's $\mathrm{r} 2$ books on the same subject.

Varro [of course De Re Rustica].

Palladius, also an agricultural writer very popular in the Middle Ages. His treatise is in 14 books, mostly in the form of a farmer's calendar.

Celsus on Medicine.

Pliny's Natural History.

Vitruvius on Architecture.

Frontinus on Strategy. (4 books.)

Lucretius's philosophical poem De Rerum Natura.

Manilius, a writer of a poem on Astrology and Astronomy. (Astronomica, 5 books.)

In Greek :

Aratus, who wrote two astronomical poems very popular among the ancients.

Dionysius, commonly called Periegetes, who wrote a description of the earth in hexameters.

Oppian, who wrote on fishing and hunting.

Apollonius Rhodius, whose Argonautica gives a description of the adventures of the Argonauts. 
Quintus Calaber, author of a Greek epic poem on the Trojan war.

Plutarch-(apparently some of the Moral writings?).

Geminus, who wrote on Astronomy.

Aelian on Tactics.

Xenophon's Anabasis and Cyropaedia.

The substantial correctness of the record made by Phillips is guaranteed by the list of books which Milton himself recommends in his treatise, though he omits some of the above books, and adds others. Among those named by Milton and omitted by Phillips are the rural parts of Virgil, Hesiod, Theocritus: also Seneca's Quaestiones Naturales. Milton also names for ethical, philosophical, and political teaching, the moral works of Plato, Xenophon, Aristotle, Cicero and the Greek poets.

Now, if we attempt to arrange the course of study, following such slight indications as are given by Milton, we find that after the initiatory year's work already adverted to (substantially grammatical), the books first to be studied are the writers on agriculture, Cato, Columella, and Varro. These will give the pupils command of all ordinary prose. After reading these books they should study in some modern author "the use of the globes and all the maps." Concurrently with this, Greek would be begun after the same fashion as Latin, and the pupil be introduced to Aristotle's physical works and the history of plants by Theophrastus. To help in these studies in so far as they were of a practical kind, all sorts of mechanical teachers might be employed-such as hunters, fowlers, fishermen, architects, engineers, etc. - in a subordinate capacity, either giving their services gratuitously or for a salary. This course of study would bring the pupil to the age of about i 7 I should say.

The pupils would nowe proceed to Latin and Greek authors on Astronomy and Geometry, and proceed to the study of Trigonometry, Engineering, Fortification, Navigation. A compendium of Physics would be here introduced, and Natural 
History, and even Anatomy and Medicine (within certain limits) studied. Milton's scheme of secondary education (in so far as it has reference to the intellect) is thus at once realistic, encyclopaedic and technical.

\section{University Stage.}

The above studies could not possibly be completed until the pupils were at least 18 years of age-the university age, as we may call it. It is at this age that the purely literary, political, theological, and philosophical course would, according to Milton's scheme, begin. The literary, by the reading of the moral parts of Plato, Cicero, Xenophon, some Greek, Latin or Italian comedies, and those tragedies which "treat of household matters, as the Trachiniae, Alcestis and the like." Then would come the study of Politics, "that they might know the beginning, end and reasons of Political Societies; that they may not in a dangerous fit of the Commonwealth be such poor, shaken, uncertain Reeds, of such a tottering Conscience as many of our great Counsellors have lately shown themselves, but stedfast pillars of the State." Next they would study Law in its grounds and practice, including Roman Law, and the Common and Statutory Law of England, and concurrently with this, on Sundays and in the evening of each day, the high matters of theology and Church History, ancient and modern, "the Hebrew tongue having been already acquired at a set hour" so that the Scriptures might be read "in their own original."

It is only after these "employments are well conquered," and consequently not sooner than the 20 th year (I presume), that the youth is admitted to a purely literary course. This is to consist of choice histories, heroic poems, Attic tragedies and all the famous political orations, "which, if they were not only read but some of them got by memory and solemnly pronounc't with right accent and grace (as might be taught), would 
endue them ever with the spirit and vigour of Demosthenes or Cicero, Euripides or Sophocles."

Last of all-that is to say in the 2 Ist year-might be studied the "organic Arts," viz. Logic, Rhetoric, Poetry, as these are to be found treated by Aristotle, Plato and others. "This," he says, "would make them soon perceive what despicable creatures our common Rimers and play-writers be; and show them what religious, what glorious and magnificent use might be made of poetry, both in divine and humane things."

This large curriculum would be concluded by literary compositions "in every excellent matter." "When fraught with an universal insight into things" will be the right season, Milton says, to form them into able writers. "Then," he goes on, "whether they be to speak in Parliament or counsel, honour and attention would be waiting on their lips. There would then also appear in pulpits other visages, other gestures and stuff otherwise wrought, than what we now sit under, ofttimes to as great a trial of our patience as any other that they preach to us." "These," he cries out, "be the studies in which our noble and our gentle youth ought to bestow their time in a disciplinary way from twelve to one and twenty unless they rely more on their ancestors dead than on themselves living."

Milton's University curriculum is, be it noted, a curriculum of Literature, Rhetoric, History, ethical Philosophy, and Law ; Science is omitted. The curriculum is Humanistic, but it, the real-Humanistic, that is to say, has regard to the substance of what is studied rather than to the formal and linguistic. 
Gymastic.

"I call a complete and generous education," he says, "that which fits a man to perform justly, skilfully and magnanimously all the offices both private and public, of peace and war." The course of discipline which he has as yet sketched out, however, would prepare only for the offices of peace; and he accordingly now proceeds to deal with gymnastic-" the exercises and recreations" that best agree and become these studies. The day should be divided into three parts devoted respectively to studies, exercise and diet.

An hour and a half before they eat at noon is to be allowed the youths for exercise and due rest afterwards; the time for this being extended according as they rise early. Their exercises should be fencing and wrestling "to keep them healthy, nimble and strong and well in breath." "It is also the likeliest means to make them grow large and tall and to inspire them with a gallant and fearless courage"; which he adds "being tempered with seasonable lectures and precepts to them of true Fortitude and Patience will turn into a native and heroick valour and make them hate the cowardise of doing wrong."

With gymnastic should be combined military exercises. "About two hours before supper, they are by a sudden alarum or watch word, to be call'd out to their military motions, under skie or covert, according to the season, as was the Roman wont : first on foot, then as their age permits, on Horseback, to all the Art of Cavalry; That having in sport, but with much exactness, and daily muster, serv'd out the rudiments of their Souldiership in all the skill of Embattelling, Marching, Encamping, Fortifying, Besieging and Battering, with all the helps of ancient and modern stratagems, Tacticks and warlike maxims, they may as it were out of a long War come forth renowned and perfect Commanders in the service of their Country." 
In this way the "Institution of Breeding" which he "delineates" shall "be equally good both for Peace and War."

As to relaxation from study and recreation, he would, after the grounds have been well laid in the first two or three years, give a holiday in Spring. He says beautifully, "In those vernal seasons of the year when the air is calm and pleasant, it were an injury and sullenness against nature not to go out and see her riches, and partake of her rejoycing with Heaven and Earth." But even this holiday he would turn to educative uses. He would have the youths ride out in companies under proper superintendence, to all quarters of the land, learning all places of strength and studying the places most suitable for harbours, ports and industries. Sometimes he would have them take to sea, and visit the navy to learn there something of naval tactics. "These ways would try all their peculiar gifts of nature, and if there were any secret excellence among them would fetch it out and give it fair opportunities to advance itself by, which could not but mightily redound to the good of this nation and bring into fashion again those old admired vertues and excellencies, with far more advantage now in this purity of Christian Knowledge."

\section{Moral, Religious and Aesthetic Training.}

The moral instruction should be direct as well as indirect. In addition to the study of Scripture prosecuted chiefly in the evening, Cebes ${ }^{1}$ and Plutarch in Greek and Quintilian in Latin should be studied in connexion with this reading; but here "the main skill and groundwork will be to temper them such

1 Tabula (a board-hence picture) Cebetis : a philosophical explanation of a picture (said to be hung in the Temple of Cronus in Athens or Thebes) symbolically representing human life, written by Cebes (?), a pupil of Sokrates, very popular in ancient times. Sometimes it has been bound up with the Enchiridion of Epictetus. 
lectures and explanations upon every opportunity as may lead and draw them in willing obedience, enflamed with the study of Learning and admiration of Vertue; stirr'd up with high hopes of living to be brave men and worthy Patriots, dear to God and famous to all ages......infusing into their young breasts such an ingenious and noble ardor as would not fail to make many of them renowned and matchless men."

Chiefly, however, the example of their master was to influence them.

At a more advanced stage when they have been prepared by "years and good general precepts" they will require "a special reinforcement of constant and sound endoctrinating to set them right and firm, instructing them more amply in the knowledge of Vertue and the hatred of Vice": "Their young and pliant affections" should with this view be led through all the moral works of Plato and Xenophon, Cicero, Plutarch etc., they will thus be perfected in the "knowledge of personal duty" and thereafter proceed to the study of Economics. Each day's work is to be closed with the study of the Bible.

Aesthetic. Milton attaches importance to music as an educational agency, but he would teach it as a relief from other studies and from gymnastic. "The interim," he says, "of unsweating themselves regularly, and convenient rest before meat may both with profit and delight be taken up in recreating and composing their travail'd spirits with the solemn and divine harmonies of Musick heard or learnt ; either while the skilful Organist plies his grave and fancied descant, in lofty fugues, or the whole Symphony with artful and unimaginable touches adorn and grace the well studied chords of some choice Composer, sometimes the Lute, or soft Organ stop waiting on elegant Voices either to Religious, martial, or civil Ditties; which if wise men and Prophets be not extreamly out, have a great power over dispositions and manners, to smooth and make them gentle from rustick harshness and distemper'd passions. The like also would not be unexpedient 
after Meat to assist and cherish Nature in her first concoction, and send their minds back to study in good tune and satisfaction."

Of Discipline in the vulgar school sense Milton says little. He believes evidently that the course of daily life which he delineates will be so attractive to boys as to make this superfluous : for, speaking of his own scheme he says, "I will strait conduct ye to a hill side, where I will point ye out the right path of a vertuous and noble Education; laborious indeed at the first ascent, but else so smooth, so green, so full of goodly prospect, and melodious sounds on every side, that the Harp of Orpheus was not more charming. I doubt not but ye shall have more adoe to drive our dullest and laziest youth, our stocks and stubbs, from the infinite desire of such a happy nurture, then we have now to hale and drag our choicest and hopefullest Wits to that asinine feast of sowthistles and brambles which is commonly set before them, as all the food and entertainment of their tenderest and most docible age."

Elsewhere he suggests, but only in a remote and incidental way, coercion ; for if "mild and effectual perswasions" and the teacher's own example fail to gain them (as he thinks they will) to an "incredible diligence," there may be "an intimation of some fear, if need be." One would like to know what Milton's own practice as a teacher was. We can imagine that sheer stupidity would not so much irritate him as make him indignant. If he vented his indignation in words the poor boy would be in a pitiable plight under the torrent of vigorous vituperation of which Milton was a master. It is not a violent supposition that a lexicon might sometimes hurtle through the air-the objective point being some crass skull. In any case we may be sure that the schoolroom 'scene' would be enacted after the grand manner of the demigods and would, doubtless, have its educative uses. 


\section{I72 JOHN MILTON, THE CLASSICAL ENCYCLOPAEDIST}

As to travel; Milton would postpone this till the youths were three or four and twenty. They would then go, "not to learn principles but to enlarge experience and make wise observation"; and, as being already cultivated men, they would be well received by foreigners of eminence.

School Buildings and Apparatus. To carry out his scheme of Education Milton proposes that a "spacious house and ground around it fit for an Academy and big enough to lodge I 50 persons" should be secured and placed under the government of one Head. 'This place should be at once school and University, "not making a remove to any other House of Scholarship" except in the case of those who desired to continue their studies in the specific faculties of Iaw and Physic with a view to being practitioners. Several such institutions ought to be founded throughout the country.

The reader of the Tractate will notice that every recommendation made by Milton is accompanied with a fierce, but wonderfully eloquent, attack on the then existing school practice, or on the melancholy results of that defective practice in every department-Social Life, Letters, Preaching, Politics, Administration and the Military Art. There is much in these passages that recalls Carlyle. Some of them I have already quoted and I shall here conclude my exposition with his invective on Universities-"And for the usual method of teaching Arts, I deem it to be an old errour of Universities not yet well recover'd from the Scholastick grossness of barbarous ages, that in stead of beginning with Arts most easie, and those be such as are most obvious to the sence, they present their young unmatriculated Novices at first coming with the most intellective abstractions of Logick and Metaphysicks; So that they having but newly left those Grammatick flats and shallows where they stuck unreasonably to learn a few words with lamentable construction, and now on the sudden transported 
under another climate to be tost and turmoil'd with their unballasted wits in fadomless and unquiet deeps of controversie, do for the most part grow into hatred and contempt of Learning, mockt and deluded all this while with ragged Notions and Babblements, while they expected worthy and delightful knowledge; till poverty or youthful years call them importunately their several wayes, and hasten them with the sway of friends either to an ambitious and mercenary, or ignorantly zealous Divinity; Some allur'd to the trade of Law, grounding their purposes not on the prudent and heavenly contemplation of justice and equity which was never taught them, but on the promising and pleasing thoughts of litigious terms, fat contentions, and flowing fees; others betake them to State affairs, with souls so unprincipl'd in virtue, and true generous breeding, that flattery, and Court Shifts and tyrannous Aphorisms appear to them the highest points of wisdom; instilling their barren hearts with a conscientious slavery, if, as I rather think, it be not fain'd. Others lastly of a more delicious and airie spirit, retire themselves knowing no better, to the enjoyments of ease and luxury, living out their daies in feast and jollity; which indeed is the wisest and the safest course of all these, unless they were with more integrity undertaken. And these are the fruits of misspending our prime youth at the Schools and Universities as we do, either in learning meer words or such things chiefly, as were better unlearnt."

By way of criticism; I would first take exception to Milton's proposal to institute isolated boy colonies. To shut up $15^{\circ}$ youths from the age of 12 to 2 I and put them through a severe curriculum of study is, altogether apart from the scheme of study which may be adopted, a proposal fundamentally unsound. Boys, like men, learn by contact with the world as it is, and in their own families they acquire that kind of intellectual and moral training which prepares them best for 
the world we live in. Milton's scheme has most of the disadvantages that attend monastic life, and is an exaggeration of the English Public School system from which even Sparta would have shrunk.

The rigid system of intellectual and physical discipline to be carried out in these prison-houses is to be condemned. Neither mind, nor body, can grow to its best if it is always laced tight and dressed in regimentals.

A second obvious criticism is that Milton in allowing only one year for learning as much Latin and Greek as was "scraped together" in seven or eight, absurdly exaggerates the aptitude of boys and the capacity of teachers.

As regards the substance of intellectual instruction: even admitting that real-naturalistic instruction is alone valuable up to the age of say 18 or 19, it certainly would not be practicable to carry boys through the extensive course of reading which Milton advocates. He enormously over-estimates the capacity of the average pupil. A boy would certainly be 15 years of age before his knowledge of Latin (even with the best teaching) or his maturity of intelligence would make it possible for him to begin to read with advantage the authors named by Milton as coming first in the curriculum. The work could simply not be done in any save the most perfunctory manner, even allowing for the fact that some of the books were to be "read to " the boys. On the ground of mere practicability, therefore, the scheme of intellectual instruction must be pronounced a wild imagination, even if it were sound educationally.

But it may be said, and said truly, these objections do not touch the substance of Milton's theory, which is this: The Real or Sensible should alone (with religion and morals) be taught until a boy is 18 or 19 years of age. Even the humble linguistic exercise of composition is to be eschewed until the boy is full of matter. Now this principle can perfectly well be given effect to if we choose to do so. We might confine youths till they had reached the age of i 8 solely to real- 
naturalistic studies. Latin and Greek, of course, we should now, on Milton's principles, exclude entirely, inasmuch as they could in these days contribute nothing to the knowledge of the youth save what was better not learned, because it would have to be unlearned. A few boys might be allowed to take up Latin and Greek on the special ground that they were to continue their education throughout the university stage in which theology, oratory, and literature generally were to be the Miltonic study. But it is doubtful whether the time required for languages of such difficulty would, on the Miltonic theory, be well spent even by the few in these days. By means of good translations in his own or in foreign modern tongues, a youth might be admitted to as much of ancient eloquence and thought as was requisite for general culture or for specialized work.

The conclusion then would be, if we translate Milton into the conditions of the igth century, that none save those ultimately going forward to the university should waste their time over the ancient languages. English, French, German, and Italian would of course take their place in all schools, on the ground that these are now the channels of all real and realistic knowledge, and at the same time are vehicles of philosophy and literature adequate to the full culture of a man. This is truly what Milton proposes when we translate him into contemporary and equivalent terms.

Even the professed philologer and theologian would study Latin and Greek (if he studied these at all) and modern languages not for their own sake, but solely for the sake of the substance of the writings to be met with in the various tongues. By the material of thought, the substance of morality, the ideas of religion, man, according to Milton, can be made all we can mentally and morally make him. Much hard work, much discipline are, doubtless, needed to acquire the material and substance of all knowledge, but the mental discipline which the curriculum of study would necessitate is not valued by Milton, 
- not thought of. It is simply the knowledge acquired, the mental equipment he cares for. By knowledge we are saved, not by discipline or training. Milton, if he were answering an opponent, would doubtless say that he had in his thoughts, implicitly, the whole idea of intellectual and moral discipline as well as instruction. But the answer is, that his theory of education does not take account of the former as an end in itself, and therefore falls to be ranked among those schemes which think that knowledge will accomplish all. Wisely remarked Milton's immediate successor in educational history, John Locke, "Men of much reading are greatly learned but may be little knowing." Mark Pattison also says, "Milton saw strongly, as many have done before and since, one weak point in the practice of schools, namely, the small result of much time. He fell into the natural error of the inexperienced teacher, that of supposing that the remedy was the ingestion of much and diversified intelligible matter. It requires much observation of young minds to discover that the rapid inculcation of unassimilable information stupefies the faculties instead of training them."

Let me by way of caution, however, repeat that Milton does not confine himself to the real of sense, but embraces in his scheme the real of the humanities. At the fitting age the youth, as we have seen, is to be introduced to literature and theology and philosophy. A strictly accurate exhibition therefore of Milton's system would show that he confines himself almost wholly to the realistic of sense (but always including moral and religious instruction and training) up to a certain age (say $\mathrm{r} 8$ ), and thereafter takes the youth into that other realm of the Real, viz. Poetry, Politics, Oratory and Philosophy.

Milton's conception of the substance of the education of a man has, if we take it as a whole, an air of magnificence. But it is crude in its general conception-not thoroughly thought out.

His prime defect is that he takes account only of a limited class of the community, and his educational views suffer from 
this. They were limited and narrow. Even judged by the needs of this limited class his curriculum of instruction is inadequate. He keeps in view the final stage of instruction, which comprehends all that is best in Humanism; but the long road that has to be traversed to reach this is occupied with Latin and Greek and the realistic instruction to be found in ancient writers. The secondary school would be on his principles a home neither of discipline nor culture.

Under Milton's scheme accordingly the mass of boys would enter life unhumanized by their education, and with their minds filled, or rather, congested, - not disciplined and trained. Even the few who went forward to university study could not, without great, perhaps insuperable, difficulty, enter on the 'organic' studies and the pursuit of literature and philosophy. Moreover instruction in the Latin and Greek languages, which alone saved Milton's primary and secondary course from pure sense-realism, would in these days be a waste of time, for in all matters of science our modern books are alone worthy of study.

Samuel Johnson in a criticism of Milton puts the antagonistic view exceedingly well : "The truth," he says, "is, that the knowledge of external nature, and the sciences which that knowledge requires or includes, are not the great or frequent business of the human mind. Whether we provide for action or conversation, whether we wish to be useful or pleasing, the first requisite is the religious and moral knowledge of right and wrong; the next is an acquaintance with the history of mankind and with those examples which may be said to embody truth and prove by events the reasonableness of opinions. Prudence and Justice are virtues and excellencies of all places. We are perpetually moralists, but we are geometricians only by chance. Our intercourse with intellectual nature is necessary ; our speculations upon matter are voluntary and at leisure. Physiological learning is of such rare emergence, that one may know another half his life, without being able to estimate his" 
skill in hydrostatics or astronomy; but his moral and prudential character immediately appears. 'Those authors, therefore, are to be read at schools that supply most axioms of prudence, most principles of moral truth, and most materials for conversation; and these purposes are best served by poets, orators, and historians. Let me not be censured for this digression as pedantic or paradoxical; for, if I have Milton against me, I have Socrates on my side. It was his labour to turn philosophy from the study of nature to speculations upon life; but the innovators whom I oppose are turning off attention from life to nature. They seem to think, that we are placed here to watch the growth of plants, or the motion of the stars. Socrates was rather of opinion that what we had to learn was, how to do good and avoid evil '."

Johnson, however, omits to notice the very large place assigned by Milton to the moral and religious education of boys. In this respect, indeed, Milton stands out conspicuously as an advocate of direct moral instruction, while the practice of schools, then and now, is to rely almost wholly on such indirect instruction as school events may yield and on the dogmatism of religious creeds. A just criticism would be that Milton did not see the importance of language and literature as a moralizing agent in the education of the young, and so dispensed with them till it was too late to make use of them.

A serious error of omission in Milton is due to his contemptuous ignoring of the work which the Baconian school of educationalists was doing. Method is not even mentioned by him. His treatise keeps steadily in view a great aim, but in other respects it presents us, not with a method, but only with a ratio studiorum or Lehrplan, and that a bad one.

Nor can we approve of Milton's giving a practical and useful turn to play. The essence of play is that it shall be useless. The objection may also be urged that Milton's course of instruction is not boyish enough for boys ; but while recog-

1 Johnson's Lives, vol. I. p. 95. 
nizing the force of this objection, I am yet disposed to agree with Mr Browning when he says", "One of the main hopes of the improvement of education lies in adopting the truth that manly and serious studies are capable of being handled and mastered by intelligent schoolboys."

Because of the obvious defects of Milton's scheme, it has been the habit of schoolmasters to treat his Tractate with something like contempt, or, at least, to ignore it. Drop the mere externalities of the scheme however and contemplate the ideas inherent in it, and we find much that is valuable: (I) A condemnation of exclusive Latin and Greek instruction with which all thinking men now agree. (2) A condemnation of the verbalism and formalism of school teaching, which also now meets with universal acceptance. (3) An advocacy of natureinstruction and of practical handwork: who is there among thinking educationalists now to question this? (4) An earnest plea for direct moral instruction: still awaiting response from our schools. (5) A denunciation of attempts at composition without material to write about. (6) Generally, the putting of the study of the real of sense and the real of the Humanities before the study of the organic arts-Grammar, I,ogic, Rhetoric : "Matter before Form," as Comenius was then preaching and which all intelligent teachers (at least theoretically) now accept. (7) The recommendation of technical instruction in its widest sense. (8) The advocacy of gymnastic and physical drill, now accepted elements in all properly organized education. (9) The teaching of Latin Grammar by means of the English tongue and not in Latin as was then, and till quite recently, universal ${ }^{2}$. Even his encyclopaedism may be defended as a necessary protest against the meagre intellectual life of the schools of his time. And greater than all was the profound conviction, which

' Educational Theories, p. 97.

2 Milton's first publication after Paradise Lost was a Latin Grammar for Beginners within the compass of $6_{5}$ pages and written in English. It is entitled Accedence Commenc't Grammar, 1669. 
he has handed down to all worthy to inherit it, of the efficacy of education to mould the jouth of a country to virtue, generosity and sacrifice. Professor Masson well says,-_" "The noble moral glow that pervades the Tract, the mood of magnanimity in which it is conceived and the faith it inculcates in the power of the young spirit are merits everlasting ${ }^{1}$."

Milton himself, remember, recognizes the ideal character of his scheme of education. For he tells us that "this is not a bow for every man to shoot in that counts himself a teacher; but will require sinews almost equal to those which Homer gave Ulysses." And in truth this is what every man is driven to say who seriously thinks about national education-its nature and its possibilities, viz. where are we to find the Educators? Few are born in the purple: how can we make the average man worthy to assume it?

Some writers would class Milton among the Realists in education, but this is only a partial truth. It is true that Milton was of opinion that the books read by boys, both in the primary and secondary stages, should treat of things, but his whole scheme of higher education is, as we have seen, literary and oratorical and musical-essentially Humanistic. The distinctive note of the earlier Humanists is that while "real" subjects should be taught, the governing studies of youth should be Language and Literature with History ; the strict Realist, on the other hand, would make the Real or Naturalistic along with Arithmetic and Mathematics dominant. Even language should be taught, as a subordinate though necessary study, mainly through things, according to the Realist, while in the case of foreign tongues it is the utilities of life that govern instruction in them-not language and literature as such. This being so, to class Milton among sense-realists is incorrect. He stands by himself. I have called him a Classical Encyclopaedist.

Note. The quotations in the above Lecture are printed verbatim from Mr Browning's edition of the Tractate (Pitt Press).

1 Professor Masson in Life of Milton. 


\section{CHAPTER XIII.}

\section{JOHN LOCKE, THE ENGLISH RATIONALIST.}

Introduction.-Value of Education.-Aim of Education.-Vigour of body.-Virtue or Morality and Good Breeding.-Habit.-Fundamental Principle of Locke,-Authority.-Enforcing of Authority, - (a) Punishment in relation to Moral Training,-(b) Punishment in relation to Instruction,- $-(c)$ Rewards.--Substance and Method of Moral Training.

JоHN LOckE was born in $163^{2}$ and died in 1704 . His Thoughts on Education were published in 1693 .

Locke is the most important English writer on education next to Ascham. I devote considerable space to him because no writer on education surpasses him in my opinion. His personal experience, however, was limited. As tutor of Lord Shaftesbury's son, and thereafter as adviser and guide of the education of that son's children, he had his attention directed to the subject practically; but his knowledge of school work was restricted to his own experience as a boy at Westminster and as a lecturer in Oxford. Hence many defects in his book and many merits; defects arising from his ignorance of the routine of the school and the difficulties which a master has to encounter; merits arising from the close and paternal relation in which he stood to his pupils. This close and paternal relation led him to see that the daily moral training had far more effect in producing the ultimate result at which all wise 
educationalists aim-cultured, virtuous, and generally well informed and capable men-than instruction in the narrower scholastic sense. He was led however to underrate both the importance and difficulties of instruction; and valuable as were his thoughts on moral training, much significance cannot be attached to his treatment of Method as applied to those subjects which all must learn, and which he says "may be had into the bargain, at a very easy rate, by methods that may be thought upon."

While residing in Holland he had corresponded with his friend Mr Clark, member for Taunton in King William's Parliament, on the bringing up of that gentleman's children; and yielding to the solicitations of many of his friends, especially of William Molyneux, his Iublin correspondent, he reduced his letters to shape and published them in 1693 under the title Some Thoughts concerning Education. 'The form in which the Thoughts were originally cast explains the want of method and the frequent repetitions.

The admirable, but loosely constructed book on The Conduct of the Human Understanding, though not professedly written as an educational treatise, ought to be read with the Thoughts, and as the complement of them, if we would understand fully Locke's real views and adequately exhibit them; for what is the conduct of the understanding, or in Spinoza's phrase Emendatio Intellectus, but education?

In my exposition I of course follow Locke closely; but I endeavour to give a more articulate shape to what he has somewhat loosely set down; and it is because I do so, that I think my exposition will be of service to the student or teacher.

Locke seems to have been ignorant of Comenius and Ascham, but he must have known Milton's Tractate, and the influence of Montaigne is everywhere conspicuous. Had it not, indeed, been for the influence of Montaigne and the circumstances in which his Thoughts were written, he could not have, I think, so entirely parted company with his philosophical system when 
he came to write on education. It is true we find a treatment which is generally in perfect consonance with the doctrine of the Essay on the Human Understanding, but there is no purposed or conscious connexion; nor could this have been expected in a book which he himself says is rather of the nature of "a private conversation" between two friends than "a discourse designed for public view"."

\section{Value of Education.}

To begin with, we must note carefully that Locke does not think of the education of the people any more than Milton does. $\mathrm{He}$ considers the education of a young gentleman only. And as he presumes that the education is domestic, his remarks are not always very applicable to schools. Still substantially, mutatis mutandis, many of his principles are of universal application. By way of introduction he points to the effects of education in a well-known passage, in the first part of which he somewhat exaggerates the influence of education.

$\S \mathrm{I}$, pp. I, 2. "A sound mind in a sound body is a short but full description of a happy state in this world. He that has these two has little more to wish for: and he that wants either of them will be but little the better for anything else. Men's happiness or misery is most part of their own making. He whose mind directs not wisely will never take the right way, and he whose body is crazy and feeble will never be able to advance in it. I confess there are some men's constitutions of body and mind so vigorous and well framed by nature, that they need not much assistance from others, but by the strength of their natural genius they are from their cradles carried towards what is excellent and by the privilege of their happy constitution are able to do wonders ${ }^{2}$."

"But examples of this kind are but few, and I think I may say that of all the men we meet with, nine parts of ten are

1 Letter addressed to Mr Clark when sending the book to him.

2 The quotations are from Quick's edition. 
what they are, good or evil, useful or not, by their education. It is that which makes the great difference in mankind. The little, or almost insensible impressions on our tender infancies, have very important and lasting consequences, and there it is (as in the fountains of some rivers) where a gentle application of the hand turns the flexible waters into channels that makes them take quite contrary courses; and by this little direction given them at first in the source, they receive different tendencies, and arrive at last at very remote and distant places."

\section{Aim of Education.}

Locke's educational aims may be summed up thus :

I. Vigour of body.

II. Virtue in the soul, with its manifestation in good breeding: wisdom in conduct. I add wisdom because towards the end of his Treatise, p. 200 , he says, "The great business of all is Virtue and Wisdom.

Nullum numen abest si sit Prudentia!"

III. Knowledge, or mental acquisition: but this subordinate to health of body, and virtue, and good breeding.

His first concern is for the corpus sanum, the "case," the "clay cottage."

I. THE BoDy.

$\mathrm{He}$ recommends absence of cockering and generally the hardening of childhood. Bare heads, especially in bed, and leaky shoes (!).

Swimming and exposure of head and person generally urged.

As to girls he says, "The nearer they come to the hardship of their brothers in their education the greater advantage they

1 The more logical order, perhaps, would be to make Wisdom a fourth head as being the fruit of II and III. 
will receive from it all the remaining part of their lives." It is of importance, however, in this climate to be careful against chills after exercise. Women guarded very strongly against tight-lacing. Nature alone can develope the frame harmoniously. P. 7 .

Diet should be simple. No flesh meat for the first three years. Careful chewing. Much bread should be eaten. Small beer to be allowed if taken with bread. Drink no more than natural thirst requires. Above all things the young should avoid wine and all strong drinks. Fruits, except stone fruits, if quite ripe, wholesome for children-in moderation of course. Early to bed and early to rise: quantity of sleep not to be limited in case of very young children; very much a matter of temperament. Children to be awoke from sleep gently ( $\$ 2 \mathrm{r}, \mathrm{p} . \mathrm{r} 6$ ), and "give them none but kind words and usage until they be come perfectly to themselves." Hard beds recommended.

\section{ViRTUe OR MoRality.}

(1) Habit in relation to early training in virtue and the hardening of body and mind.

"Due care being had to keep the body in vigour and strength, so that it may be able to execute and obey the orders of the mind; the next and principal business is, to set the mind right, that on all occasions it may be disposed to consent to nothing but what may be suitable to the dignity and excellency of a rational creature.

"If what I have said in the beginning of this discourse be true, as I do not doubt but it is, viz. that the difference to be found in the manners and abilities of men is owing more to their education than to anything else, we have reason to conclude that great care is to be had of forming children's minds and giving them that reasoning early, which shall 
influence their lives always after; for when they do well or ill the praise or blame will be laid there, and when anything is done awkwardly, the common saying will pass upon them, that it is 'suitable to their breeding.'

"As the strength of the body lies chiefly in being able to endure hardships, so also does that of the mind. And the great principle and foundation of all virtue and worth is placed in this, that a man is able to deny himself his own desires, cross his own inclinations, and purely follow what reason directs as best, though the appetite lean the other way.

"The great mistake I have observed in people breeding their children has been that this has not been taken care enough of in due season, that the mind has not been made obedient to discipline and pliant to reason, when at first it was most tender, most easy to be bowed." [ "The most early habits are the most lasting," says Bishop Butler-a truism.]

"It is not that the performance of a single act is in itself to be deprecated perhaps; but the formation of Habit is all important ${ }^{1}$.

"When a child is young, therefore, obedience and control of temper and sacrifice of desires must be taught. Why should a child who has had his will up to the age of $1_{4}$ or $1_{5}$ be expected to submit to checking then? And if checked, with what hope of true success?" Pp. 20, 2 I.

"Try it in a horse or dog or any other creature and see whether the ill and resty tricks they have learned when young are easily to be mended when they are knit; and yet none of these creatures are half so wilful and proud or half so desirous to be masters of themselves and others as man." P. 22.

"The having desires accommodated to the apprehensions and relish of those several ages is not the fault; but the not

1 Erasmus says: Plato "adolescentem quod lusisset aleam graviter increpuit: qui quum dixisset, Sic objurgas ob rem parvam? At parvum non est inquit assuescere." Apophth. vir. 
having them subject to the rules and restraints of reason: the difference lies not in having or not having appetites but in the power to govern and deny ourselves in them. $\mathrm{He}$ that is not used to submit his will to the reason of others when he is young, will scarce hearken to submit to his own reason when he is of an age to make use of it. And what kind of a man such a one is like to prove is easy to foresee." P. 22.

Locke expresses his surprise that men turn out morally as well as they do, when we consider how they are brought up. The bad example of parents, the violence which takes the place of reason, the love of dress encouraged in girls, lying and equivocations seen in the family or overlooked when done for the interest of the family, over-eating and drinking, etc.

"It seems plain to me," he says, "that the principle of all virtue and excellency lies in a power of denying ourselves the satisfaction of our own desires, where reason does not authorize them. This power is to be got and improved by custom, made easy and familiar by an early practice. If therefore I might be heard, I would advise that contrary to the ordinary way, children should be used to submit their desires and go without their longings, even from their very cradles. The first thing they should learn to know should be that they were not to have anything because it pleased them, but because it was thought fit for them. If things suitable to their wants were supplied to them, so that they were never suffered to have what they once cried for, they would learn to be content without it, would never with brawling and peevishness contend for mastery, nor be half so uneasy to themselves or others as they are, because from the first beginning they are not thus handled. If they were never suffered to obtain their desire by the impatience they expressed for it, they would no more cry for it than they do for the moon." P. 25.

The main thing accordingly is the formation of good habits. 
"Habits," he says, "work more constantly and with greater facility than Reason, which when we have most need of it, is seldom fairly consulted and more rarely obeyed." This can be accomplished only by seeing that certain things are done and done rightly. And this you will do by watchfulness and by encouragement, and kind words and reminders and not by force. Concentrate yourself on one or two habits at a time, and when these are pretty well formed go to others.

It will be noticed (and this is a guide to the understanding of Locke) that just as he advocates the hardening of the body he advocates the hardening of the mind by refusing children all they want, simply because they want it. This kind of hardening is, I think, irrational. The true principle of action is rather this-Iet children have what they want, unless their having it is hurtful to themselves or hurtful or annoying to others. Training to virtue is a training not to sacrifice for the sake of sacrifice, but to sacrifice of some one object to another, of the lower to the higher, the worse to the better. To this, children should be daily inured; and Dugald Stewart well says :

"To a certain hardness of character, not unfrequently united with an insensibility to the charms of poetry and eloquence, may partly be ascribed the severe and forbidding spirit which has suggested some of the maxims in his Tract on Education. He had been treated himself it would appear with very little indulgence by his parents, and probably was led by that filial veneration, which he always expressed for their memory, to ascribe to the early habits of self-denial imposed on him by their ascetic system of ethics the existence of those moral qualities which he owed to the regulating influence of his own reason in fostering his natural dispositions, and which under a gentler and more skilful culture might have assumed a still more engaging and amiable form. His father, who had served in the Parliament's army, seems to have retained through life that austerity of manners which characterized his 
puritanical associates; and notwithstanding the comparative enlargement and cultivation of Mr Locke's mind, something of this hereditary leaven, if I am not mistaken, continued to operate upon many of his opinions and habits of thinking. If in the Conduct of the Understanding he trusted (as many have thought) too much to nature and laid too little stress on logical rules, he certainly fell into the opposite extreme in everything connected with the culture of the heart, distrusting nature altogether and placing his sole confidence in the effects of a systematical and vigilant discipline."

\section{(2) Fundamental Principle of Training-Authority.}

The condition essential to the training of children to the habit of virtue is the recognition by them of the authority of the educator-be he parent or master.

"Those then that intend ever to govern their children should begin it while they are very little, and look that they perfectly comply with the will of their parents. Would you have your son obedient to you when past a child, be sure then to establish the authority of a father as soon as he is capable of submission and can understand in whose power he is. If you would have him stand in awe of you, imprint it in its infancy; and as he approaches more to a man, admit him nearer to your familiarity; so shall you have him your obedient subject (as is fit) whilst he is a child, and your affectionate friend when he is a man." P. 27.

"Thus much for the settling your authority over your children in general. Fear and awe ought to give you the first power over their minds, and love of friendship in riper years to hold it, for the time must come when they will be past the rod and correction, and then if the love of you make them not obedient and dutiful, if the love of virtue and reputation keep them not in laudable courses, I ask, what hold 
will you have upon them to turn to it? Indeed, fear of having a scanty portion if they displease you, may make them slaves to your estate but they will be nevertheless ill and wicked in private: and that restraint will not last always. Every man must sometime or other be trusted to himself and his own conduct and he that is a good and virtuous and able man, must be made so within. And therefore what he is to receive from Education, which is to sway and influence his life, must be something put into him betimes: habits woven with the very principles of his nature and not a counterfeit carriage and dissembled outside, put on by fear, only to avoid the present anger of a father who perhaps may disinherit him."

Locke pushes the necessity of establishing a feeling of awe and fear in the child's mind a great deal too far. Respect for authority and obedience can be secured by better and juster means. The assumption is, that there is no instinctive feeling of reverence in the human mind. If there be this, then all we have to do, is to conduct ourselves as rightful authorities ought to conduct themselves, in order to secure respect and obedience. Then the affections of children being active we can make obedience a pleasure to them through their regard for our affection and esteem. Mr Daniell truly says, "Had Locke been a parent he might have known that there was no greater need of imperiousness and severity in dealing with infancy than in dealing with adolescence."

\section{(3) Enforcing of Authority.}

(a) Punishments in relation to moral training.

To secure the above results, which (as has been shown) are to be obtained by a process of training or discipline under authority, does not involve punishment.

"To bring_a young man to [the Habit of] submitting his appetite to Reason, I know nothing which so much contributes as the Love of Praise and Commendation." * * "Make 
his mind as sensible of Credit and Shame as may be: and when you have done that you have put a principle into him which will influence his actions when you are not by $*{ }^{*} *$ and which will be the proper stock whereon afterwards to graff the true principles of Morality and Religion." $\$ 200$.

This is Locke's great instrument of moral training. But the child may not respond to praise or blame. What then? Must we compel from without by flogging? Locke does not answer this wholly in the negative, though he denounces severe punishment.

$\S 43$, p. 19. "A great severity of punishment does but very little good, nay, great harm in education, and I think it will be found that cet. par. these children who have been most chastised seldom make the best men." Now why should a child care for your orders, or for your praise, or blame at all? Locke does not ask or answer this save by assuming the existence of an unquestioned authority. But awe must be implanted and for this purpose severity must be increased if necessary.

Severity so as to secure awe and obedience should however be got over, before children have memories to retain the beginning of it. In this way it will seem natural to them and be unconsciously established and more rational relations may then gradually be established. That the bringing up must be rational is evident from this that we desire to produce an inclination to virtue from within (Positive Morality). If there be too much curbing and severity the spirits are abased and broken, the timid never become worth anything, although it is to be admitted on the other hand that those who are by nature lively and spirited may throw off the oppression and become able men.

$\S 46$, p. 30. "He that has found a way, how to keep up a child's spirit, easy, active and free, and yet at the same time to restrain him from many things he has a mind to, and to draw him to things that are uneasy to him; he I say that knows how to reconcile these seening contradictions has in my opinion 
got the true secret of education." But still he has suggested no means but praise and blame.

$\S 47$, p. 30. "The usual lazy and short way by chastisement and the rod which is the only instrument of government that tutors generally know or ever think of, is the most unfit of any to be used in education."

$\S 48$, p. 30. "This kind of punishment contributes not at all to the mastery of our natural propensity to indulge corporal and present pleasure and to avoid pain at any rate, but rather encourages it, and therefore strengthens that in us, which is the root from whence spring all vicious actions and all irregularities of life. For what other motive, but of sensual pleasure and pain does a child act by who drudges at his book against his inclination, or abstains from eating unwholesome fruit that he takes pleasure in, only out of fear of a whipping? He in this way only prefers the greater corporal pleasure or avoids the greater corporal pain. And what is it to govern his actions and direct his conduct by such motives as these? What is it I say but to cherish that principle in him which it is our business to root out and destroy? And therefore I cannot think any correction useful to a child, where the shame of suffering for having done amiss, does not work more upon him than the pain."

$\$ 49$, p. 3 I. "This sort of correction naturally breeds an aversion to that which it is the tutor's business to create a liking to. How obvious is it to observe that children come to hate things which were at first acceptable to them when they find themselves whipped and chid and teased about them? And it is not to be wondered at in them, when grown men would not be able to be reconciled to anything by such ways. Who is there that would not be disgusted with any innocent recreation, in itself indifferent to him, if he should with blows or ill language be hauled to it when he had no mind; or be constantly so treated for some circumstances in his application to it? This is natural to be so. Offensive circumstances 
ordinarily infect innocent things, which they are joined with : and the very sight of a cup, wherein any one uses to take nauseous physic, turns his stomach, so that nothing will relish well out of it, though the cup be never so clean and well-shaped and of the richest materials."

$\S 50$, p. 31. Such a sort of slavish discipline makes a slavish temper. The child submits and dissembles obedience whilst the fear of the rod hangs over him: but when that is removed and by being out of sight he can promise himself impunity, he gives the greater scope to his natural inclination; which by this way is not at all altered, but on the contrary heightened and increased in him; and after such restraint breaks out usually with the more violence; or $(\S 5 \mathrm{I})$ " If severity carried to the highest pitch does prevail and works a cure upon the present unruly distemper it is often by bringing in the room of it a worse and more dangerous disease by breaking the mind; and then in the place of a disorderly young fellow, you have a low-spirited moped creature, who, however with his unnatural sobriety he may please silly people, who commend tame, inactive children, because they make no noise, nor give them any trouble, yet at last will probably prove as uncomfortable a thing to their friends, as they will be all their lives a useless thing to themselves and others."

What Locke means in his apparently contradictory statements is this: Do not exercise severity, do not resort to punishment even in the details of moral training. Attract and guide to goodness, do not coerce. But you are helpless to begin with and all through, unless you have authority and unless that authority is recognized. Accordingly, this central virtue in the child-respect and obedience-must be established in him somehow and at all hazards as the foundation of all possible moral training. Any amount of severity is justifiable in the interests of authority pure and simple. But this once established, coercion, castigation and chiding are hurtful. 
It may be here noted that at the time Locke wrote great severity was practised by both parents and schoolmasters. Hallam says, "The mode of treatment seems to have been passionate and barbarous severity, alternating with foolish indulgence. The spirits [of children] were often broken down and their ingenuousness destroyed by the former, their habits of self-will and sensuality confirmed by the latter" (Lit. Hist. II. I 83).

\section{(b) Punishment in relation to instruction.}

As might be expected Locke returns to this question of coercion and punishment in connexion with intellectual work, and speaks substantially as follows:

$\mathrm{He}$ objects to forcing children to learn. We must take advantage of the natural disposition to learn when we find it and make the most of it. We are not always in the humour to do even the things which we are really fond of. Why then expect children to be always ready? The seasons should be warily observed and taken advantage of, and if we have to call on them to apply themselves when they are not disposed, we should prepare their minds for the task-dispose them to it, and so gradually accustom them to get a dominion over themselves and to be able on choice to turn from one thing to another, and so forth :

This course of procedure, even if desirable, is manifestly only practicable where there are only one or two pupils under a man who lives with them. In my opinion it is not desirable. We have to form the habit of putting a pressure on one's self. This is the truest of all discipline. It is not merely an intellectual, but a moral, discipline. Energizing of will to overcome difficulty is the root of all virtue. Moreover, a fixed time for studies once recognized is more easily observed from day to day. The formation of intellectual habit is just as easy' as the formation of moral habit. 
Chiding is as bad as blows, Locke says, in giving instruction just as in moral training. A nod or look should suffice, and when words are used they should be calm and serious, not passionate. Children easily distinguish between passion and reason. Rating breeds a dislike both of the teacher and of the lesson. It has to be remembered that beating, as such, does no real good. It is the shame and disgrace of it that are moral in their effects. And if these be not found, the beating soon loses its terror.

Generally, Locke's doctrine of punishment is this, that every motive to do right, including attention to work, should be exhausted by the master and parent before beating is resorted to. The child should even be reasoned with, not on broad general grounds, but with such reasonings as are suited to his age. He deprecates beating for intellectual defects or for idleness or want of attention to study, until these are so often repeated as to show perverseness and deliberateness of disobedience. They then become moral faults, nay the supreme moral fault-the fault of disregard of authority; and for this, in accordance with the principles already laid down, he would flog soundly.

He guards parents, however, from elevating trifles into serious offences. ( $(80$, p. 59.) "Inadvertency, carelessness, and gaiety" in the child, account for much. "Nor is that to be hastily interpreted obstinacy or wilfulness which is the natural product of their age or temper." "With a gentle hand the faults natural to childhood should be set right as time and age permit." "Nor is relapse into minor faults to be construed into wilfulness."

At the same time if there be unmistakable wilfulness amounting to obstinacy and rebellion, beating must be resorted to, and then it should be so severe as not to need repetition. An obstinately disobedient child must be bent. Locke tells us of a mother, who, receiving her child home from nurse and finding her peevish and disobedient, beat her for seven 


\section{JOHN LOCKE, THE ENGLISH RATIONALIST}

successive mornings without effect, and succeeded in bending her only on the eighth. He applauds her for her perseverance. His approbation of the monstrous conduct of this woman reveals the weakness of Locke's position. By such pitting of the adult will against the child's will we abuse our strength. If we succeed, it is only an apparent success :- that is to say, the boy yields externally, but is full of passionate hate towards his master-a hate which carries its demoralization into every corner of his being. Or he is, when we think him bent, in truth broken in spirit, and all manhood and inner moral growth, which must be free to be true, rendered impossible-a melancholy result. Nor is this all, for in such contests the adult is simply pitting his obstinacy against the child's and so strengthening the latter by exercise and example. Another illustration of the weakness of Locke's position is his recommendation that when a child cries under a beating he should be beaten more if he does not stop cryinga wholly unnatural proceeding. He assumes that this continued crying indicates continued perversity and rebellion, which it by no means does. The continued crying is generally nervous and automatic. Again, he would beat till a child said he was sorry for his fault. Now neither child nor man can be expected at a moment when their passions are roused to admit their fault (save hypocritically). This is to expect passion and calmness of mind to coexist, which is impossible. Give the beating, I should say, if it must be given, and have done with it.

I am not prepared to say that we must never beat; but, assuredly, beating should be always merely a vehicle for conveying the disapprobation with which we regard the boy's conduct; it, in truth, should be merely an emphatic way of saying, "You are behaving badly and all the world would think so." By means of a beating, a boy, who persists in a perverse wrong-doing without ever realizing its badness, may have its badness and the shame of it carried home to him in a way which nothing else can do. 
In cases of obstinacy, I should say, always give an alternative. Never push the contest to an extreme. "If you don't do this, then you must do that, or lose such or such a pleasure." Thus avoid a pitched battle. For by such battles you do one of two things certainly - either break the boy or confirm his obstinacy which is roused to passionateness and increased persistency. Another course with very young children is to shunt them. One engine advancing against another brings about damage to both when the collision takes place, and, probably, complete destruction to one. Run to the points and shunt one of them into a siding, and you are safe. In like manner, distract the perversely obstinate child by presenting some new object or idea. When the fit is over, you may calmly remonstrate, and with effect.

Locke, while requiring that the parent, and consequently the master, shall establish his authority so as to be regarded with awe by his pupils, urges strongly (as we have seen) that this relationship, once established, shall be gradually relaxed, and that, as the boy grows older, there should be a growing equality and familiarity of treatment. In this way the pupil will grow up to regard the master or the parent as his best friend, he says. Yes, truly his best friend in a sense : but it seems to me that there can never be in such cases the equality of all true friendship between father and son. The father will remain "a governor" till the end, though "not a bad sort of fellow."

\section{(c) Rezvards.}

\$ 52, p. 31. "Beating then and all other sorts of slavish and corporal punishments are not the discipline fit to be used in the education of those we should have wise, good, and ingenuous men: and therefore very rarely to be applied, and that only in great occasions and in cases of extremity. On the other hand to flatter children by rewards of things that are pleasant to them is as carefully to be avoided." "Esteem and disgrace" are the proper instruments 
of discipline. But you must inspire them with a love of the one and fear of the other if they are to operate. This is certainly difficult, but it is the secret of education. The parents must caress and commend when their children do well, and show a cold exterior when they do ill.

The remaining remarks of Locke may be summed up as follows: To make the sense of esteem and disgrace sink deeper they should be followed with agreeable and disagreeable things respectively-not as rewards but as the necessary consequences of this or that kind of action. They thus associate well-doing with the attainment of desires and vice versâ. In this way they will be gradually shamed out of their faults and in love with all the ways of virtue.

Beating or chiding have only the effect of causing annoyance, with the miscarriage that brought it on them, whereas if their pain be not regret for having done amiss the beating will have no true effect. It only patches up and skins over a sore, but does not reach to the bottom. Ingenuous shame and the apprehensions of displeasure are the only true restraint.

This love of good reputation is not (it is true) the real principle and measure of virtue (for that is the knowledge of duty and the desire to please God), yet it is that which comes nearest to it, and is therefore the proper guide and encouragement of children. The rebukes and chidings which the faults of children sometimes make necessary should not only be in sober, grave, and impassionate words but also alone and in private; but the commendations they deserve should be in the presence of others.

To conclude; if a right course be taken with children there will not be so much need of the application of the common rewards and punishments as we imagine. All their innocent folly, playing and childish actions are to be left free and unrestrained as far as they consist with due respect to those present, and that with the greatest allowance. These faults should be left to years to cure. If we reprove too much for 
small things, we make correction in more serious cases of less avail. A gamesome humour should be rather encouraged, the authority of parents being however so established that a look or word will suffice to quiet them.

Rules. In connexion with moral discipline generally Locke speaks of Rules and says,

"Avoid heaping up rules. Few years require few rules." If there are too many it is simply impossible for the nature of children to remember them all always and also for you always to punish the infringement. Thus your rules fall into contempt and the important and unimportant are confounded. Especially in the matter of manners, these are best learned by example and commendation when things are rightly done rather than by rules. Rules, I may here add, should not be laid down before offences, but should arise out of offences.

\section{(4) Substance and Method of Moral Training.}

Dealing, as Locke does, with the moral upbringing of youth and giving prominence to that, he first by way of introduction considers the comparative advantages of a private and public education. He considers that "the breeding of a young man at home in his father's house and under a good governor is much the best and safest way to the great and main end of Education." He considers that the roughness, trickery, rudeness, sometimes called "spirit," acquired among a company of boys drawn from homes of very varying kind, are, so far from being an advantage, a positive evil. There are faults no doubt in a domestic education, but these are of a kind which can easily be cured. Shamefacedness and absence of that modest confidence which are characteristics of good breeding can easily be guarded against by accustoming a boy to his father's society and to free intercourse with his visitors. In any case $(\S 70)$ 
"Virtue is harder to be got than a knowledge of the world: and if lost in a young man is seldom recovered." In a school, even a well-disposed and competent master cannot have the requisite opportunities for forming the minds and manners of his pupils, which require constant attention and "particular application to every single boy." The "waggeries and cheats" etc. practised among schoolboys will not make a thriving man. "He that lays the foundation of his son's fortune on virtue and good breeding takes the only sure and warrantable way." The restraint of discipline it is which makes a great nation.

$\$ 70$, p. 50. "It is virtue, direct virtue which is the hard and valuable part to be aimed at in education and not a forward pertness or any little arts of shifting. All other considerations and accomplishments should give way and be postponed to this. This is the solid and substantial good, which tutors should not only read lectures and talk of, but the labour and art of education should furnish the mind with, fasten there, and never cease, till the young man had a true relish for it and placed his strength, his glory and his pleasure in it."

(Note here that Locke contrasts Domestic Education with Public Education in the English sense. The Scottish and German system would be in his view the next best; -in fact the best, if we consider that Locke's system, even if the best theoretically, is impracticable for all save a few wealthy. We have only to introduce morality as a conscious end and object into our public day schools to have as perfect a system as the conditions of life admit of.)

Virtue, then, by which is here meant the subjection of our inclinations to duty, is the main thing. How is this to be taught? According to Locke almost wholly by training : not by instruction.

The great governing rule of Method here is, that you yourself afford in your own person an example of virtue.

\$ 7 I, p. 51. "Maxima debetur pueris rezerentia." You must 
do nothing before them which you would not have them imitate -nothing which you would regard as a fault in your pupil.

But virtue is a general term, and we must be watchful of our pupils so that vices as they arise may be checked and tendencies to virtue encouraged. If we would detect these incipient vices we should watch children at play when they fancy themselves unnoticed.

Locke does not exhaust the various vices and virtues, nor does he follow any intelligible order in discussing them, as might have been expected from the author of the Essay on the Human Understanding. He seems very much to take them up as they occur to him, and deals with their superficial aspect only; but in spite of this, there are few books better suited to form an elementary manual of morals and manners than the sections in Locke's treatise which deal with the various moralities, or rather immoralities. I shall take up only a few of those which Locke deals with, as a specimen of his way of looking at moral training.

\section{(r) Love of Pozver.}

When watching children at play we shall see that special development of selfishness which we call Love of Power. This must be curbed, because it is the root of almost all injustice and contention and if we do not restrain it we cannot lay the "foundations of a good and worthy man." To check this vice Locke proposes that "children ( 107) $_{\text {) should never }}$ have what their inclinations lead them to ask for, unless it be the satisfaction of their actual needs. They should be trained so that they would not dare to express their desires when these were mere fancies, and the parent should as occasion served reward them for their general restraint and self-denial by indulgence."

Locke here, it seems to me, advocates an unnatural and irrational system, as I have previously pointed out. If a child 
desires a box of sweetmeats or a cricket-ball or a pair of skates, why should he not desire them? And if he desire them why should he not express his desire to his parents or master? Locke's system, in fact, introduces a forced and artificial relation between parents and children, out of which love and sympathy and that mutual confidence which is the source of all true moral influence over the young cannot possibly grow. If we lose this, what have we gained? Nothing. Moreover, the suggestion is based on an inadequate moral analysis. Children are just like ourselves. IV'e desire many things which we cannot get : there is nothing wrong in desiring them, or in expressing our desires. The wrong consists in not sacrificing our desires to higher considerations. So with children: let Johnny have his box of sweetmeats by all means, if there is no higher consideration forbidding it. If there be; $\iota . g$. if his having them prevents his brothers or sisters having what is necessary for them; or if it be a purely selfish desire, he intending to eat them all himself; or if it be a question between spending the money in gratifying this desire or in relieving the hunger of some poor destitute child, put these motives before him and get him himself to crucify his love of sweetmeats for the sake of these higher things. A child well brought up will do so. It is the supplying of the higher motives wherewith to suppress the lower that moral training consists in. The mere law or command of a superior is to be resorted to only if moral motives fail. And even then,-not by way of defeating the child's desire, but with a view to impress him with your conviction of its unworthiness. How can you do this at all, if you refuse satisfaction on every side indiscriminately, thus substituting your ipse dixit for the true spirit of morality?

Locke is, I think, more successful in suggesting the true way of combating selfishness and love of power when he speaks of the virtues of liberality and justice. 
JOHN LOCKE, THE ENGLISH RATIONALIST 203

\section{(2) Liberality.}

Encourage children to be kind and generous to each other, and let them see that the esteem and commendation of others always attend the exercise of generosity.

\section{(3) Justice.}

\$ I Io, p. 90. "Great care is to be taken that children transgress not the rules of justice, and whenever they do, they should be set right, and if there be occasion for it severely rebuked." Through ignorance, children are "apt to deviate from just measures of right and wrong, and, consequently, even the least slip in this great social virtue should be taken notice of and rectified." Wonder and abhorrence should be expressed at any unjust act, and the foundations of justice laid in the practice of liberality. As they grow in years they will understand better what justice means, and if then or indeed at any time an act of injustice proceeds not from mistake but perverseness, and gentle rebukes fail, "rougher remedies" must be resorted to. For example, the father or tutor may keep forcibly from them something they think their own, and so show how little advantage they are likely to gain by appropriating unjustly what is another's so long as there are people stronger than they. But the best way is when they are yet young to implant in them an ingenuous detestation of all injustice.

\section{(4) Cowardice and Fortitude.}

Again, in speaking of the moral fault of cowardice, and the virtue of fortitude, Locke suggests the hardening of children to blows and making light of their pains lest we soften them too much. Nay we are sometimes to subject them to pain with a view to hardening. This strikes us as unsound. There are pains enough without inventing them. And again it is unnatural, because a child should express its suffering and be sympathised with reithin limits, so long as the expression is not 
excessive. It is the excess which is wrong. If I knock my knuckles against a door I probably utter some impatient word, and I confess I think none the worse of myself for doing so. I should be ashamed, however, of myself if I gave any sign of pain even when I burnt my finger if there were sufficient reason for concealing my suffering. So with children. Let us be reasonable and not exaggerate acts which in themselves are truly of little importance, of great importance only when higher considerations enter. By just and rational treatment we shall, nay we cannot but, form the highest character. Artificial pretences are out of place.

\section{(5) Cruelty.}

On the subject of cruelty, Locke thinks that the tendency which many children have to inflict pain on the lower animals should be carefully watched, and in connexion with this he animadverts strongly on the manners of wealthy children towards servants.

\section{(6) Sauntering or Idleness.}

First make sure whether it be at his lessons only that the boy is idle. If he is active in other things there is hope of him, and by counsel or severe measures you may get him to reform.

If, however, the idleness be constitutional the case is more difficult. The only remark of Locke's of any value with respect to such cases is to watch the boy and see whether he has a liking for any one thing and encourage this. For the main object is to get him to overcome the constitutional tendency, by getting him to work at something, be it what it may-beetlecollecting or carpentering, if not Latin or French.

The above question naturally suggests again to Locke's mind the question of compulsion, and he finds the means of 
getting children to attend to lessons by making their play a task. Order a boy to whip his top and not to stop for a certain time, and the boy will at once get disgusted with the amusement and gladly accept his reading or writing, as a change. Whatever elder people choose to make a reward or a task can be made so.

Playthings. As to playthings: let the children have very few, and invent what more they want for themselves. Nothing is more hurtful than an excessive abundance of toys. It tends to create luxurious habits and immoderate desires.

\section{(7) Lying.}

§ 13 I. "Lying is so ready and cheap a cover for any miscarriage and so much in fashion among all sorts of people that a child can hardly avoid observing the use which is made of it on all occasions, and so can scarce be kept without great care from getting into it. But it is so ill a quality and the mother of so many ill ones that spawn from it and take shelter under it, that a child should be brought up in the greatest horror of it imaginable." The first lie, he thinks, should be treated with surprise and astonishment that such a thing should be possible. The second with coldness and displeasure of all about him. If this fail, the lying may be held to be deliberate and therefore a sign of obstinacy. In accordance with his fundamental idea, beating must now be resorted to. When children commit faults they will "like the rest of the sons of Adam be apt to make excuses." This borders on untruth and they must be urged to be ingenuous. But when they confess ingenuously they must be commended for this, and not punished for the fault which they have confessed. And this condonation of the fault should be thorough; no allusion should afterwards be made to it. If sometimes there be a few slips in truth do not be too ready to take notice of them, lest the boy should feel that he has lost his reputation with you, than which nothing can be more 
hurtful. When you have once detected him in a lie you must be most vigilant and severe.

\section{(8) Truth and Good Nature.}

Having laid the foundations of virtue in a true knowledge of God, the next thing is to keep him exactly to speaking the truth and to cultivate his "good nature." By this Locke means his benevolence, for as he truly remarks "injustice generally springs from too great love of ourselves and too little of others."

\section{(9) Wisdom.}

Wisdom is the managing of one's affairs ably and with foresight in this world. It has however a moral side. In its full sense it can only be learned from experience and observation, but we can at least guard the young, with a view to wisdom, against that "ape of wisdom" cunning, resorted to by those who cannot gain their ends by direct ways. Accustom them in truth and sincerity to a submission to reason, and as much as may be to reflection on their actions.

\section{(10) Good-breeding.}

On the subject of good-breeding Locke has some good observations. He speaks at length and with such wisdom and knowledge of the world that I would recommend teachers to read what he says. Indeed it is to young men and women alone that his remarks can be serviceable. In the case of mere boys, I think we have only to cultivate good-nature and a moderate estimate of themselves. The rest will come from the experience of life, and above all from the society they keep : for as Locke truly says, "the tincture of company sinks deeper than the outside." The breaches of good breeding he says may be all avoided by observing this one rule, "Not to think meanly of ourselves and not to think meanly of others." 


\section{JOHN LOCKE, THE ENGLISH RATIONALIST 207}

\section{(I I) Relision.}

Religion being ( $(\mathrm{I} 36)$ " the foundation of all virtue, there ought very early to be imprinted on a child's mind a true notion of God as of the independent Supreme Being, Author and Maker of all things, from Whom we receive all our good, Who loves us and gives us all things": but this without any attempt to enter into the subtler questions of Deity. Simple prayer, night and morning, should be practised. 


\section{CHAPTER XIV.}

JOHN LOCKE-continued.

Knowledge or Learning,-(a) Method,-(b) Materials,-

(c) The Recreative,-(d) Qualification of the Teacher.

LOCKE is a utilitarian in this sense that he holds that a boy should learn what will be useful to him as a man in intercourse with his fellows and in the conduct of ordinary affairs. He is also cyclopaedic, because he advocates the learning of the elements of many things. In both these respects Locke is in accord with almost every thinker in these days. It is only a gradually decreasing number of secondary schoolmasters who differ from him. Were it not however for the argument of the treatise on the Conduct of the Understanding we should quarrel with him as to his restricted use of the term "useful." Next to moral principles and a religious habit of mind, nothing surely is so "useful" to a man as a vigorous and sound judgment. The materials and methods of instruction have to be considered in view of this supreme end-what Locke himself would call Wisdom. The great merit of Locke is that he denounced the rigid classicism of his time which led to instruction exclusively in the instruments of knowledge and of thought-not in knowledge and thought themselves. As regards materials of instruction Locke was a Realist as opposed to the Formalists, but this does not mean that he was a 
naturalistic realist. At the same time, it must be admitted that he had, like Comenius, the conspicuous defect that he was unable to comprehend the education which was to be found in literary expression and was not alive to the intellectual discipline which grammatical studies yield.

(a) Method. As regards method in instructing, Locke makes many pertinent remarks, but it had never occurred to him, though a philosopher, that method had a scientific basis in psychology. He dealt with the whole subject in a somewhat light, but by no means perfunctory, spirit. He considers that good methods may be easily found, and that as children naturally love knowledge, the task of instruction should not be so very difficult. "Knowledge," he says, "is grateful to the understanding as light to the eyes." Outside the three "R's" his remarks are rather directed to what ought to be the matter of instruction than to the hore of method, although his pages are full of admirable suggestions. Knowledge may be had "at a very easy rate by good methods," but he does not suggest anything save what are rightly to be called wise expedients rather than methods strictly so called. The most valuable of his remarks to be found in the Thoughts on the subject of method in general are these: $\left(\$ \mathrm{r}_{7}\right)$ " Children's minds are narrow and weak and usually susceptible but of one thought at once. Whatever is in a child's head fills it for the time, especially if set on with any passion. It should, therefore, be the skill and art of the teacher to clear their heads of all other thoughts while they are learning of anything, the better to make room for what he would instil into them, that it may be received with attention and application, without which it leaves no impression. The natural temper of children disposes their minds to wander. Novelty alone takes them; whatever that presents they are presently eager to have a taste of and are as soon satisfied with it. They quickly grow weary of the same thing, and so have 
almost their whole delight in change and variety. It is a contradiction to the natural state of childhood for them to fix their fleeting thoughts." Again he says that the success of instruction depends on the activity of the pupil's mind relatively to the instruction given and to its attractiveness. In this Locke is right. But he is wrong, I think, when he says that everything must be made pleasant and attractive. The object of education in so far as it is discipline is, as I have already pointed out, to induce a child to put pressure on himself and to initiate intellectual effort under a sense of duty. This is one of the "hardships of the mind" which every young person has to endure and overcome. It is moral as well as intellectual in its effect. In some of his utterances Locke seems to recognize this fact himself, but he certainly does not take firm hold of it. The sum of the matter is that the instruction should always be as pleasant and attractive as it can possibly be made, and for this we rely on Method.

(b) Materials. As regards the matter of knowledge Locke lets us clearly understand that this is quite secondary. Virtue, wisdom, and breeding, these are the chief ends of education. Other things he only "allows to be necessary." We must however give an account, however brief, of this portion of Locke's treatise.

Reading. The letters of the alphabet (Locke thinks) may be learned as an amusement. Let them be pasted on a many sided bale or on four dice, and let children amuse themselves by casting these and seeing what letter is thrown. Then when the letters are known let the same process be followed, the players seeing after every throw who has thrown most words. Thus much for learning to read. Cheat your pupil into it if you can. In this way he will soon be able to read some "easy pleasant book," Aesop's fables being the best, and if it has pictures in it so much the better. Reynard the Fox he also recommends. Learning by heart and learning to read should 
not be made to "clog one another," as it is essential that the reading should always be associated with pleasure. The Creed and Ten Commandments and Lord's Prayer for example should not be learned by heart from a book, but by the oral repetition of others. Locke complains of the want of pleasant and suitable reading for children. He objects to the promiscuous reading of the Bible, for obvious reasons.

Writing. This is to be begun only when the pupil can read English well, and first he should be taught to hold his pen right, and this before he is suffered to put it to paper. Then the proper placing of the paper and of his body is to be attended to. He should then trace over with black ink, letters lithographed in red ink. Then he may write without tracing. $\mathrm{He}$ recommends also shorthand.

Drazuing. This is recommended as a part of the education of a young gentleman: but solely because of its future utility.

French and Latin. As soon as he can speak English it is time for him to learn some other language. This is to be talked into him, and begun early, that the organs of speech may be adapted to the French pronunciation. A year or two will enable a boy to speak French.

Latin. When he can speak and read French well he should proceed to Latin. This should be learned in the same way, by talking and reading. "Latin I look upon as absolutely necessary to a gentleman." But can there be anything more absurd than forcing boys to learn Latin who will never need it afterwards, entering perhaps some trade? But custom is so strong that even tradesmen think that their children have not an orthodox education unless they learn Lilly's Grammar.

The ordinary way of learning Latin is bad. The true way is by talking it into him, and thus he will learn easily what is usually whipped into boys over a period of 6 or 7 years. "Our knowledge [even of foreign tongues] should all begin in the things of sense and not in the abstractions of Logic and Metaphysics." § 166, p. 140. 
If a man cannot be got who can teach your son in the way suggested, the next best thing is to give him some easy book with an interlinear word for word translation-taking care that he makes himself perfect in one lesson before he goes to another. But as a preliminary it will be necessary that he first get the accidence by heart. More than this of grammar he need not have until he can himself read "Sanctii Minerva'."

If a boy encounters difficulties in reading Latin do not trouble him to find them out, but tell him and help him on. Everything is to be made as easy and pleasant as possible. "Languages are to be learned by rote, custom, and memory."

The grammar of a language he admits is to be studied critically, but only by professed scholars. In further considering the method of teaching Latin, he says that after some facility has been attained by reading the interlinear book, he may then be advanced to Justin or Eutropius, helping himself with an English translation. If this involves rote work what then? All languages are really learned by rote and are only well known when the words to express thought come readily without thought and without the conscious application of grammatical rules.

Grammar is not on this account to be said to be of no use, but children in grammar schools should not be perplexed with it. People acquire great correctness and elegance in speaking a language who know nothing about its grammar. Conversation is that whereby people acquire languages. If grammar is to be studied with a view to greater correctness of speech it ought to be the grammar of our own tongue. At present one would think that all our youths were being trained to be teachers of the dead languages.

Grammar, then, should be taught to those who desire to write or speak with elegance and to scholars, but only after they can speak and write the tongue whose grammar they study. [Note however that the accidence is to be got by

1 A treatise on Latin Grammar rather than a Latin Grammar (now forgotten). 
heart.] Its proper place in truth is as an introduction to rhetoric. The speaking and reading are all that is necessary to those who merely want a gentleman's acquaintance with a tongue: the critical knowledge is for those who have to write it with exactness. In any case there is no doubt in Locke's mind that those are tormented about grammar to whom it does not at all belong, "I mean children at the age wherein they are generally perplexed with it in grammar schools." $\S \mathrm{I} 68$, pp. I $45,146$.

He can scarcely find words strong enough to express his contempt for Latin in those schools that prepare for ordinary middle-class life. Latin is necessary to a "gentleman"; at least it was so in Locke's time, but the argument of utility, in the vulgar sense of that word, breaks down when we consider its employment as an instrument of education in the schools of the bourgeoisie.

Let the scholar translate Latin into English, but as the mere learning of words is a very unpleasant business let him "join as much real knowledge with it as he can," beginning still with that which lies most obvious to the senses, such as is the knowledge of minerals, plants, and animals, and particularly timber and fruit trees * * "more especially geography, astronomy, and anatomy." (§ I69.) [Here we see the influence of Milton.] But whatever he is taught let virtue be the chief end.

Spite of all that has been said, a boy if he has to go to school must submit to the usual routine, but by all means try to get him exempt from writing Latin themes and, above all, verses. As to themes, Locke considers it an Egyptian tyranny to ask boys to write themes when they have not, by reason of their age and ignorance, the materials. He suggests their being induced to speak to a subject which they know something about without preparation.

As to verses the school practice is absurd and indefensible. Locke had an aversion to poetry. He says that if a boy 
shows a poetic vein it should be stifled and suppressed, if he is not to grow up to a dislike of all other "callings and businesses" and to be led into frivolous company. Poetry and gaming go together. And even if any one desires to cultivate the poetic vein he will do it best by reading the poetscertainly not by writing Latin verses.

Locke further objects to learning parts of classical authors by heart as tending to make a pedant, and yet he commends the learning of beautiful passages, if selected for this reason, that they are beautiful. As to exercising the memory, that is not improved by learning by heart. The learning one class of things by heart does not improve the memory for others. "What the mind is intent upon and careful of that it remembers best" $\left(\sum_{17} 6\right)$; and if we add to this order and method we have done all that can be done. Yet Locke does not mean that there should be no exercise of memory. Useful things and fine sayings might well be learned by heart and frequently called for that they may not be forgotten.

Greek. When a youth is grown up he may acquire the Greek tongue for himself if he desire it, without the aid of a tutor. Greek is for a professed student and is not necessary to the equipment of a gentleman.

Geography. While a child is learning French and Latin he should learn things through these-arithmetic, geometry, geography, chronology and history.

Geography should be begun with the globe; as the leading outlines being dependent entirely on the eye will be learned readily.

Arithmetic. When he has the natural parts of the globe in his memory it may then be time to begin arithmetic, which is the easiest and first sort of abstract reasoning that the mind is accustomed to and of universal application. A man cannot have too much of it.

Along with this, the globe should again be studied, advancing from the terrestrial to the celestial globe. Then 
the planetary system should be taught to him; but always begin with what is plain and simple, and settle that well in the pupils' heads before proceeding further. "Give first one simple idea and see that they take it right and perfectly comprehend it, before you go further, and then add some other simple idea which lies next in your way to what you aim at, and so proceeding by gentle and insensible steps children, without confusion and amazement, will have their understandings opened and their thoughts extended farther than could have been expected." (\$ I 8 I. $)^{1}$

Geometry. The six books of Euclid should be learned in the ordinary school course: but it is in the essay on the Conduct of the Human Understanding, not here, that we find Locke's estimate of mathematics in education. $\mathrm{He}$ there says (Fowler's edition, section viı, p. 23):-

"I have mentioned mathematics as a way to settle in the mind a habit of reasoning closely and in train; not that I think it necessary that all men should be deep mathematicians, but that, having got the way of reasoning, which that study necessarily brings the mind to, they might be able to transfer it to other parts of knowledge, as they shall have occasion. For, in all sorts of reasoning every single argument should be managed as a mathematical demonstration; the connexion and dependence of ideas should be followed till the mind is brought to the source on which it bottoms, and observes the coherence all along; though in proofs of probability one such train is not enough to settle the judgment, as in demonstrative knowledge."

Chronology. A boy should have a general knowledge of the great dates and epochs as preparatory, along with geography, to the proper understanding of history.

History. This delights the young, and they should read history in Latin, e.g. Eutropius, Justin and Curtius, and thus prepare themselves for the more difficult authors. They need not be troubled as to the period at which they begin, because

1 The teaching of Locke's philosophy is to be seen in this. 
their chronology will keep them right. As boys grow up, history is an important subject as "the great mistress of prudence and civil knowledge."

Ethics. This having been all along taught by practice rather than by rule, nothing more is needed than what the Bible, and, later, Tully's offices afford. Yet it is worthy of notice here that while Locke relies mainly on the formation of moral habits, he yet considers that the study of morality as maxims and precepts-in other words, instruction in the substance of morality-should enter into school-work.

Civil Law. This should be studied in Puffendorf and Grotius. There he will be instructed in the natural rights of men and in the foundations of Civil Society. A virtuous young man who knows Latin and the Civil Law and writes a good hand, may be turned out into the world with the certainty that he will "find employment and esteem everywhere." Civil law and history are in Locke's opinion "studies which a gentleman should constantly dwell upon and never have done with."

Law (Municipal). A gentleman should not be ignorant of the law of his own country by studying the ancient books of the Common Law, and "taking a view of our English constitution and Government." Then in connexion with this he should read the history of his own country.

Rhetoric and Logic. These are not to be learned from books of rhetoric and logic, but from the study of good models and by practice.

Style. As to style, youth should be trained to write, being practised first in narrative and then in epistolary composition. A gentleman should labour to get facility, clearness, and elegance, in expressing himself in his own tongue; and "to this purpose he should be daily exercised in it." Locke is bitterly satirical on the neglect of English composition in schools. "To mind what English his pupil speaks or writes is below the dignity of one bred up amongst Latin and Greek." 
Natural Philosophy. Locke thinks that the works of nature "are contrived by a wisdom and speak by ways too far surpassing our faculties to discover or capacities to conceive, for us ever to be able to reduce them into a science!"

There are two parts of Natural Science-that which has to do with Spirit and that which has to do with Body. The study of Spirit or Spirits ought to precede that of Body, not as a science but as an enlargement of mind "towards a fuller comprehension of the intellectual world to which we are led both by Reason and Revelation" (\$ 190). He thinks the best way of doing this would be the perusal of Bible history, in a book written for the young. This is all the more necessary "because matter being a thing that all our senses are constantly conversant with, it is so apt to possess the mind and exclude all other beings but matter, that prejudice grounded on such principles often leaves no room for the admittance of spirits or the allowing any such thing as immaterial beings in rerum natura; when yet it is evident that by mere matter and motion none of the great phenomena of nature can be resolved: to instance but that common one of gravity, which I think impossible to be explained by any natural operation of matter or any other law of motion but the positive will of a superior Being so ordering it." ( $\left({\text { I } 92 .)^{\prime}}^{\prime}\right.$ The world, he says, is full of systems of Natural Philosophy, but as there is no true or certain science I conclude that none of them are to be read, though a gentleman may look into some of them to fit himself for conversation. Yet Locke adds laudation of the "incomparable Mr Newton's" application of Mathematics to Natural Philosophy.

Locke evidently means that too much occupation with the things of sense has a tendency to extrude moral and spiritual ideas from the mind of youth. This is much better put in

${ }^{1}$ Locke tries to explain the Noachian Deluge by the alteration of the centre of the earth's gravity by the will of God. 
the Conduct of the Human Understanding (Fowler's edition, section Ix.), where he says, "Outward corporeal objects, that constantly importune our senses and captivate our appetites, fail not to fill our heads with lively and lasting ideas of that kind. Here the mind needs not to be set upon getting greater store; they offer themselves fast enough, and are usually entertained in such plenty, and lodged so carefully, that the mind wants room or attention for others that it has more use and need of. To fit the understanding therefore for such reasoning as I have been above speaking of, care should be taken to fill it with moral and more abstract ideas; for these not offering themselves to the senses, but being to be framed to the understanding, people are generally so neglectful of a faculty they are apt to think wants nothing, that $I$ fear most men's minds are more unfurnished with such ideas than is imagined. They often use the words, and how can they be suspected to want the ideas?"

We may fitly conclude Locke's views of the subjects and methods of instruction with his own words, "The tutor should remember that his business is not so much to teach his pupil all that is knowable as to raise in him a love and esteem of knowledge, and to put him in a right way of knowing and improving himself when he has a mind to it." $\$ 195$, p. 171.

(c) The Recreative. When we reflect that Locke was a physician and recall his remarks about the importance of having a body which would be a willing servant of the mind, his almost total omission of all that comes under the head of Gymnastic is strange. In Gymnastic in the form of games, apart from its influence on the body, there is also a species of moral training of great value which ought to have commended the subject to him. Nay in public schools it is often the chief moral training which those boys receive who are inapt to learn. When Locke speaks of bodily exercises he has in view only those exercises which make an accomplished gentleman 
and contribute to an easy bearing in society and to the enjoyment of life.

Dancing for example is to be taught because it gives an easy and graceful motion to the body and "manliness."

Music Locke sets little store by, but admits it as a recreation, since we cannot be always at work.

Riding the "great horse" he commends as necessary to gentlemen, but fencing he discourages as leading to quarrels and duelling.

As to recreations in addition to the usual exercises of the body, Locke recommends gardening, husbandry, and working in wood. Recreation "is not being idle but easing the wearied part by change of business."

Again, he says, "nothing is recreation which is not done with delight." All sorts of manual occupations might be taken to, e.g. varnishing, graving, cutting precious stones, etc., etc.

(d) The Qualifications of a Teacher, and his personal relation to his Pupil. (\$94.) "The great work of a governor is to fashion the carriage and form the mind, to settle in his pupil good habits and the principles of virtue and wisdom; to give him by little and little a view of mankind, and work him into a love and imitation of what is excellent and praiseworthy; and in the prosecution of it to give him vigour, activity, and industry. The studies which he sets him upon are but as it were the exercises of his faculties and employment of his time, to keep him from sauntering and idleness, to teach him application and accustom him to take pains, and to give him some little taste of what his own industry must perfect. For who expects that under a tutor a young gentleman should be an accomplished critic, orator, or logician; go to the bottom of metaphysics, natural philosophy or mathematics, or be a master in history or chronology? though something of each of these is to be taught him; but it is only to open the door, that he may look in, and as it were begin an acquaintance, but not to dwell there ; 
and a governor would be much blamed that should keep his pupil too long and lead him too far in most of them. But of good breeding, knowledge of the world, virtue, industry and a love of reputation he cannot have too much; and if he have these he will not long want what he needs or desires of the other. And since it cannot be hoped he should have time and strength to learn all things, most pains should be taken about that which is most necessary, and that principally looked after which will be of most and frequentest use to him in the world."

In teaching, he says, try to dispose the mind of your pupil to his work, but remember the instability of children's minds and be easy with them. To rate and chide and punish is to instil a hatred of the lesson hour, and moreover it confuses the child's mind, so that he does not know what he is doing or what you are saying to him. (\$ 167.) "It is as impossible to draw fair and regular characters on a trembling mind as on a shaking paper. The great skill of a teacher is to get and keep the attention of his scholar; whilst he has that he is sure to advance as fast as the learner's abilities will carry him; and without that, all his bustle and pother will be to little or no purpose. To attain this he should make the child comprehend (as much as may be) the usefulness of what he teaches him and let him see by what he has learnt that he can do something which he could not before. To this he should add sweetness in all his instructions and by a certain tenderness in his whole carriage make the child sensible that he loves him and designs nothing but his good, the only way to beget love in the child which will make him hearken to his lessons and relish what he teaches him. Nothing but obstinacy should meet with any imperiousness or rough usage. All other faults should be corrected with a gentle hand, and kind engaging words will work better and more effectually upon a willing mind, and even prevent a good deal of that perverseness which rough and imperious usage often produces in well-disposed and generous minds. It is true, 
obstinacy and wilful neglect must be mastered even if it cost blows to do it: but I am apt to think perverseness in the pupils is often the effect of frowardness in the tutor; and that most children would seldom have deserved blows, if needless and misapplied roughness had not taught them ill nature and given them an aversion for their teacher and all that comes from him. Inadvertency, forgetfulness, unsteadiness and wandering of thought are the natural faults of childhood, and, therefore, when they are not observed to be wilful, are to be mentioned softly and gained upon by time."

He concludes his treatise by stating that he has made no pretension to write a full and "just" tractate, but only to record some general views "regarding the main end and aims of education, and these designed for a gentleman's son," and he commends them to those who "dare venture to consult their own reason in the education of their children rather than rely wholly upon old custom." 


\section{CHAPTER XV.}

\section{JOHN LOCKE-concluded.}

Conduct of the Understanding.-Method and Intellectual Discipline: Words: Judgments : Reasonings.

LockE's method in the department of instruction is not so much a method in any philosophic acceptation of the term as a collection of empirical rules and hints as to the easiest way of disposing of the difficulty of getting the work of mere learning well over. One might rightly conclude that Locke had never fairly faced the question of the discipline of intelligence as opposed to mere instruction, were it not for the Conduct of the Understanding - the last of his writings. In this book the training and discipline of the intelligence is the theme, and while treating of this, many sound rules of general method are given and vividly illustrated. This essay, as Hallam truly says, is a "treatise on the moral discipline of the intellect." I shall first give a few extracts bearing on method generally and then on discipline of the intellect. 
(1) Method generally-Step by Step-Little by Little-Predisposing the mind of the Pupil-Labour.

\section{The analytic method. $(\$ \times \times \times 1 \times 1 \times)^{1}$}

"Things that in a remote and confused view seem very obscure must be approached by gentle and regular steps; and what is most visible, easy, and obvious in them, first considered. Reduce them into their distinct parts; and then in their due order bring all that should be known concerning every one of these parts into plain and simple questions; and then what was thought obscure, perplexed and too hard for our weak parts, will lay itself open to the understanding in a fair view, and let the mind into that which before it was awed with, and kept at a distance from as wholly mysterious."

\section{Step by step: graduation of studies. (\$ $\mathrm{xxxix.)}$}

"The surest way for a learner in this, as in all other cases, is not to advance by jumps and large strides; let that which he sets himself to learn next be indeed the next; i.e. as nearly conjoined with what he knows already as is possible; let it be distinct but not remote from it : let it be new, and what he did not know before, that the understanding may advance; but let it be as little at once as may be, that its advances may be clear and sure. All the ground that it gets this way it will hold. This distinct, gradual growth in knowledge is firm and sure; it carries its own light with it in every step of its progression in an easy and orderly train; than which there is nothing of more use to the understanding. And though this perhaps may seem a very slow and lingering way to knowledge, yet I dare confidently affirm that whoever will try it in himself or any one he will teach, shall find the advances greater in this method than they would in the same space of time have been in any other he could have taken."

1 Fowler's edition. 


\section{Little by little. The nere out of the old. (\$ $\mathrm{xxxIx.)}$}

"I therefore take the liberty to repeat here again what I have said elsewhere, that in learning anything, as little should be proposed to the mind at once as is possible; and, that being understood and fully mastered, to proceed to the next adjoining part yet unknown, simple, unperplexed proposition belonging to the matter in hand, and tending to the clearing what is principally designed."

\section{Predisposing the mind of the Pupil and co-operation} of the Teacher. (\$xxx.)

"He that will observe children will find that even when they endeavour their utmost, they cannot keep their minds from straggling. The way to cure it I am satisfied is not angry chiding or beating, for that presently fills their heads with all the ideas that fear, dread, or confusion can offer to them. To bring back gently their wandering thoughts by leading them into the path and going before them in the train they should pursue without any rebuke or so much as taking notice (where it can be avoided) of their roving, would I suppose sooner reconcile and inure them to attention than all those rougher methods, which more distract their thought and, hindering the application they would promote, introduce a contrary habit."

\section{Labour necessary. ( $\mathrm{xxxviI.)}$}

In his Thoughts Locke would have everything, as we found, made easy for the young learner, but in the Conduct of the Understanding he says,

"We are born ignorant of everything. The superficies of things that surround them make impressions on the negligent, but nobody penetrates into the inside without labour, attention, and industry. Stones and timber grow of themselves, but yet there is no uniform pile with symmetry and convenience to 
lodge in, without toil and pains. God has made the intellectual world harmonious and beautiful without us; but it will never come into our heads all at once; we must bring it home piecemeal, and there set it up by our own industry, or else we shall have nothing but darkness and a chaos within, whatever order and light there be in things without us."

\section{(2) Discipline of the Intellect.}

I do not suppose anyone would be disposed to quarrel with the substance of Locke's views on moral training and discipline, nor yet in these days at least with his advocacy of a wide range of study, for boys, so long as the range was not so wide as to dissipate all the powers and train none. But I imagine all men who have thought about educational principles and aims must concur in feeling that instruction given on Locke's plan as contained in the Thoughts, would fail to give discipline or power to the intelligence. This would not be a matter to grieve over were it not that we cannot separate the intellectual and moral nature, and that the discipline of the intellect is a discipline of the will, and indirectly a training to virtue.

In the Conduct of the Human Understanding, however, we find the necessary supplement to the Thoughts on this point as on others, for it is in fact a treatise on mental Discipline: and it is to this valuable essay that we must go, if we wish to know what Locke's idea was of the proper aim of education as regards the intellect. He there shows what a sound intellect and habit of mind are and what an unsound. His characteristics of the former constitute his educational ideal as regards intellect, his remarks on the latter point out what we have to guard against and correct both in ourselves and in those we educate. 


\section{Words and Judgments.}

Discipline is to be obtained by the analysis of words as the vehicles of things, the analysis and reconstruction in our own minds of the reasonings which we encounter in literature and by the exercise of our own reason. On these points let us see what Locke says.

\section{Analysis of Words. ( $(\mathrm{xv}$.}

"The sure and only way to get true knowledge is to form in our minds clear settled notions of things, with names annexed to those determined ideas. These we are to consider and with their several relations and habitudes, and not amuse ourselves with floating names, and words of indetermined signification, which we can use in several senses to serve a turn."

Again he says (Fowler's edition, § xxIx.):

"I have copiously enough spoken of the abuse of words in another place ${ }^{1}$, and therefore shall upon this reflection that the sciences are full of them, warn those that would conduct their understandings right, not to take any term howsoever authorised by the language of the schools, to stand for anything till they have an idea of it. A word may be of frequent use, and great credit, with several authors, and be by them made use of as if it stood for some real being; but yet, if he that reads cannot frame any distinct idea of that being, it is certainly to him a mere empty sound without a meaning; and he learns no more by all that is said of it, or attributed to it, than if it were affirmed only of that bare empty sound. They who would advance in knowledge and not deceive and swell themselves with a little articulated air, should lay down this as a fundamental rule not to take words for things, nor suppose that names in books signify real entities in nature till they can frame clear and distinct ideas of those entities."

1 In the Essay on the Human Understanding. 
Elsewhere :

"Words are not made to conceal, but to declare and show something. Where they are by those who pretend to instruct, otherwise used, they conceal indeed something; but that they conceal is nothing but the ignorance, error or sophistry of the talker; for there is in truth nothing else under them."

\section{Analysis of the substance of Reading.}

When he speaks of Reading and the uselessness of it without analysis and thought, he has some remarks which notwithstanding their length I may here quote with advantage to all who read. $\$ \mathrm{xx}$.

"This is that which I think great readers are apt to be mistaken in. Those who have read of everything, are thought to understand everything too; but it is not always so. Reading furnishes the mind only with materials of knowledge; it is thinking makes what we read ours. We are of the ruminating kind, and it is not enough to cram ourselves with a great load of collections; unless we chew them over again they will not give us strength and nourishment. There are indeed in some writers visible instances of deep thoughts, close and acute reasoning and ideas well pursued. The light these would give would be of great use, if their reader would observe and imitate them; all the rest at best are but particulars fit to be turned into knowledge; but that can be done only by our own meditation, and examining the reach, force, and coherence of what is said ; and then, as far as we apprehend and see the connexion of ideas, so far it is ours; without that, it is but so much loose matter floating in our brain. The memory may be stored, but the judgment is little better, and the stock of knowledge not increased, by being able to repeat what others have said, or produce the arguments we have found in them. Such a knowledge as this is but knowledge by hearsay, and the ostentation of it is at best but talking by rote, and very often upon weak and wrong principles. For all that is to be 
found in books is not built upon true foundations, nor always rightly deduced from the principles it is pretended to be built on. Such an examen as is requisite to discover that, every reader's mind is not forward to make; especially in those who have given themselves up to a party, and only hunt for what they can scrape together, that may favour and support the tenets of it. Such men wilfully exclude themselves from truth and from all true benefit to be derived by reading. Others of more indifferency often want attention and industry. The mind is backward in itself to be at the pains to trace every argument to its original, and to see upon what basis it stands and how firmly; but yet it is this that gives so much the advantage to one man more than another in reading. The mind should by severe rules be tied down to this, at first, uneasy task; use and exercise will give it facility. So that those who are accustomed to it, readily, as it were with one cast of the eye take a view of the argument and presently, in most cases, see where it bottoms. Those who have got this faculty, one may say, have got the true key of books and the clue to lead them through the mizmaze of variety of opinions and authors to truth and certainty. This young readers should be entered in, and showed the use of, that they might profit by their reading. Those who are strangers to it will be apt to think it too great a clog in the way of men's studies, and they will suspect they shall make but small progress, if, in the books they read, they must stand to examine and unravel every argument, and follow it step by step up to its original.

"I answer, this is a good objection, and ought to weigh with those whose reading is designed for much talk and little knowledge, and I have nothing to say to it. But I am here inquiring into the conduct of the understanding in its progress towards knowledge; and to those who aim at that, I may say, that he who fair and softly goes steadily forward in a course that points right, will sooner be at his journey's end than he 
that runs after every one he meets, though he gallop all day full speed.

"To which let me add, that this way of thinking on, and profiting by what we read, will be a clog and rub to any one only in the beginning: when custom and exercise have made it familiar, it will be despatched on most occasions without resting or interruption in the course of our reading. The motions and views of a mind exercised that way are wonderfully quick; and a man used to such sort of reflections sees as much at one glimpse as would require a long discourse to lay before another, and make out in an entire and gradual deduction. Besides, that, when the first difficulties are over, the delight and sensible advantage it brings mightily encourages and enlivens the mind in reading, which without this is very improperly called study."

\section{Reasoning and Principles.}

Then when he speaks of the necessity of reasoning, and resting our convictions on principles, he points out how generally men fail to use their reason. \$vi.

"Few men (he says) are from their youth-(observe from their youth) -accustomed to strict reasoning, and to trace the dependence of any truth, in a long train of consequences, to its remotest principles and to observe its connexion; and he that by frequent practice has not been used to this employment of his understanding, it is no more wonder that he should not, when he is grown into years, be able to bring his mind to it, than that he should not be, on a sudden, able to grave or design, dance on the ropes, or write a good hand, who has never practised either of them.

"Nay, the most of men are so wholly strangers to this, that they do not so much as perceive their want of it; they despatch the ordinary business of their callings by rote, as we say, as they have learnt it; and if at any time they miss success they impute it to anything rather than want of thought or skill." 
Again ( $($ XLIV.) :

"To accustom ourselves in any question proposed, to examine and find out upon what it bottoms. Most of the difficulties that come in our way, when well considered and traced, lead us to some proposition, which, known to be true, clears the doubt and gives an easy solution of the question: whilst topical and superficial arguments, of which there is store to be found on both sides, filling the head with variety of thoughts and the mouth with copious discourse, serve only to amuse the understanding, and entertain company, without coming to the bottom of the question, the only place of rest and stability for an inquisitive mind, whose tendency is only to truth and knowledge."

Here then in these quotations we have laid down with sufficient clearness and vigour of language, wherein intellectual virtue consists in almost all the operations of the understanding. We now know what is the educational aim as regards intelligence. Is this intellectual excellence, the issue of which is truth and wisdom, to be acquired by simply wishing for it? Certainly not. It is a habit of mind to which we have to be trained or to train ourselves, and is to be attained only (save in the case of genius) by a slow and laborious process of discipline. "What then," Locke says, "should be done in the case?" (§vi.) "I answer, we should always remember what I said above that the faculties of our souls are improved and made useful to us just after the same manner as our bodies are. Would you have a man write or paint, dance or fence well, or perforn any other manual operation dexterously and with ease; let him have ever so much vigour and activity, suppleness and address naturally, yet nobody expects this from him unless he has been used to it, and has employed time and pains in fashioning and forming his hand, or outward parts, to these motions. Just so it is in the mind, would you have a man reason well, you must use him to it betimes, exercise his mind in observing 
the connexion of ideas, and following them in train. Nothing does this better than Mathematics, which therefore I think should be taught all those who have the time and opportunity, not so much to make them mathematicians as to make them reasonable creatures; for though we all call ourselves so, because we are born to it if we please, yet we may truly say, nature gives us but the seeds of it: we are born to be, if we please, rational creatures; but it is use and exercise only that make us so: and we are indeed so, no farther than industry and application have carried us. And, therefore, in ways of reasoning, which men have not been used to, he that will observe the conclusions they take up must be satisfied they are not all rational."

\section{Elsewhere he says ( $\S \mathrm{vi}$.$) ,$}

"What then can grown men never be improved or enlarged in their understandings? I say not so; but this I think I may say, that it will not be done without industry and application, which will require more time and pains than grown men settled in their course of life will allow to it, and therefore very seldom is done. And this very capacity of attaining it by use and exercise only brings us back to that which I laid down before, that it is only practice that improves our minds as well as bodies, and we must expect nothing from our understandings any farther than they are perfected by habits."

\section{Conclusion.}

Locke has been called a Realist and Cyclopaedist, and perhaps if we are to classify him he would fall under these designations as compared with other men of his time were we to consider the Thoughts alone; but the Conduct of the Understanding throws fresh light on his position.

As to Encyclopaedism he himself says: "Others that they may seem universally knowing, get a little smattering in every- 
thing. These may fill their heads with superficial notions of things, but are very much out of the way of attaining truth or knowledge." \$xvir.

The general object of all instruction he puts before us in the following words ( $\$ \mathrm{xIx}$.): "The business of education is not to make the young perfect in any one of the sciences, but so to open and dispose their minds as may best make them capable of any, when they shall apply themselves to it. * * It is therefore to give them this freedom that I think they should be made to look into all sorts of knowledge and exercise their understanding in so wide a variety or stock of knowledge. But I do not propose it as a variety and stock of knowledge but a variety and freedom of thinking; as an increase of the powers and activities of the mind, not as an enlargement of its possessions."

It is now, I should say, sufficiently clear that if we wish fully to understand Locke's educational views we must read his Thoughts and his Conduct of the Understanding together. And if we do so we find on his own showing, not that Virtue in the moral sense and good manners and general information constitute the sole educational aim, but also Virtue of the Intellect. We also find on his own showing that this latter virtue is truly a training to accurate knowledge of things and words and the putting of a man in possession of his own Reason. We further find that an intellectual result so high is to be attained only by labour, by exercise, by discipline. Let us then read his educational system back from this its admitted aim, and we find it in complete discord with the prevalent tone of the section of the Thoughts which has to do with intelligence and instruction. It is in childhood and boyhood that we can alone sow the seeds of a good habit of Intelligence as well as of a good habit of Will according to Locke himself. The intelligence then has to be trained and disciplined as well as the moral nature. The materials of that training we may take from Locke's Thoughts, if we please, 
but the mode of procedure suggested by him is always vitiated by the exclusion of toil and the overcoming of difficulty. His method is in the Essay essentially subverted by himself. It seems accordingly to be a necessary consequence of Locke's position that through Language and Literature (not therefore excluding other instruments) we can best give that very discipline which Locke finds to be necessary to the full growth of Reason.

In respect then of Intellectual as well as Moral aims Locke, properly interpreted, is more of a Humanist than a Realist-an unimaginative Humanist-but yet a Humanist, though not of course in the narrow, classical sense. In respect of the matter of instruction he wisely includes much that did not till recently enter into the curriculum of schools, but he specially guards against too exclusive an occupation of the mind with sense-knowledge in a passage which I have quoted and which is repeated in the Conduct of the Understanding in another and a better form, a repetition which shows the importance he attached to this point. It may seem from the Thoughts that he at least verges on superficial encyclopaedism, a characteristic generally of the Sense-realists; but he even guards against this in a passage also cited above. He desires that boys in reading their own tongue or learning a foreign one read about things; in other words acquire knowledge as well as words, or rather, with words; and he also desires that many subjects should be taught which in his time were (and still are) neglected, but this does not constitute him a Realist in the naturalistic sense. He merely as a philosopher saw that young people must be occupied first and chiefly with the concrete. In this he agrees with Comenius and Milton, and every other competent writer. Encyclopaedism, let me add, in the vulgar sense of the word is a great error in the education of the adolescent, but during the sense and acquisitive period it is to be commended in order that we may attain our ultimate aim, which is that men 
should have a rational attitude to all knowledge, and be open to the influences and experiences and questions of life from day to day. Encyclopaedism, not of acquired knowledge, but of faculty and interest-that is what we aim at.

In respect then both of Aim, Method, and Matter of Education I claim Locke as essentially a Humanist, who had gone astray on the subject of language and discipline in his Thoughts, while he corrected himself in his Conduct of the Understanding. Had he deliberately connected the latter work with the former he would have seen the true significance, and indeed the necessity, of language-discipline in the school. By what other road indeed save Language and Mathematics is it possible for a man to reach that Ideal of Reason which he sketches in the more advanced book, the statement of his latest thoughts and not published till after his death? Locke's supreme defect, which detracts from his Humanistic claims, was his inability to see the educative effect of literature as such, and his entire ignorance of the relation of the aesthetic emotions to the moral and religious education of youth.

I have dwelt longer on Locke than on any other educational writer because I consider him the greatest of them all, in spite of his attitude to Language and Literature, and his encyclopaedism. After all, the encyclopaedism is justifiable from his point of view; for he was considering the all-round education of a "young gentleman" only; nor did he for a moment contemplate that all the subjects he recommends should be taught in schools. As to the middle and artizan classes, he belonged to his own epoch and considered that a knowledge of the Bible and of their own trades would suffice. Notwithstanding his debt to Rabelais, and still more to Montaigne, his educational conceptions are in the truest sense his own?

1 His Essay on Study (collected from his Joumal) should be read as an appendix 10 the Conduct of the Understanding. I1 is printed by Quick at the end of his edition of the Thoughts. 


\section{CHAPTER XVI.}

\section{HERBERT SPENCER, THE MODERN}

SENSE-REALIST.

I HAD not intended in this volume to speak of the educational system of any contemporary, but on reflection it seemed to me that an exception should be made in the case of Mr Herbert Spencer, whose little volume has had so wide a circulation. And this because I consider him to be the most eminent and most logical representative of the Naturalistic School of Philosophy, sometimes called Sensationalist, Utilitarian and Phenomenalist ${ }^{1}$. It is most instructive I think to have before us an illustration of the fact that the philosophy of a man must determine his educational theory and his advice to the world as to educational practice.

It is in the bearing of a philosophical theory on Moral Education-the ethical ideal which we propose to ourselves in educating - that we see the true significance of the philosophy we profess or affect, and it is this to which I would chiefly refer in the subsequent remarks.

But first, in justice to Mr Spencer, I must say something on his educational aim. It is "Complete Living." No one can take exception to the phrase so far as it goes, but when we look to its definition by Mr Spencer himself, we find that it

1 Not that any of these terms accurately describes Mr Spencer's philosophical position. 
practically means the adaptation of man to his environmentenvironment of nature and of other men with whom he is associated in a political society- "in what way to treat the body; in what way to treat the mind; in what way to bring up a family; in what way to behave as a citizen; in what way to utilize those sources of happiness which nature supplies; how to use all our faculties to the greatest advantage of ourselves and others." If we learn to do all this we have attained to "Complete Living." But inasmuch as we cannot exhaust a complete preparation, we must lay chief stress on the most important subjects.

The subject of primary importance is the preservation of health and life. Therefore teach physiology, that is to say, in the sense of Hygiene.

Next comes preparation for making a living, and as all industrial activities rest ultimately on science, the subject next in importance to physiology is Science in general and in particular.

After this will naturally come instruction in the rearing of offspring. This also depends on Science. Then also the moral discipline of offspring can be illuminated only by mental science.

Next come the functions of the Citizen-History properly understood and presented, and Economics. The key is here again Science.

Finally, those occupations which promote the enjoyment of life and are for leisure are not to be neglected, 'but postponed; and even these things Literature, Art, etc., though it may not be at first sight obvious, rest for their true appreciation on Science. "Accomplishments, the fine Arts, Literature, etc.," all those things which constitute the efflorescence of civilization should be wholly subordinate to that instruction and discipline on which investigation rests. " $A s$ they occupy the leisure part of life, so should they occupy the leisure part of education." 
Science, also, is not only best for knowledge, but for intellectual discipline. Nay also, it has direct bearing on the moral perceptions and the religious emotions. Thus to the question "What knowledge is of most worth?" the uniform reply is 'Science.' And to the question "What discipline is of most worth?" the answer is again 'Science'; and this even in the moral and religious sphere.

We see in all this the most logical and lucid exposition of the educational theory of the Sense-realistic school. It rests on a philosophy of man, which amounts to this, that man's task on this earth is, like that of any other sentient organism, to adapt himself to his environment in order that he may live comfortably, and, as a condition of comfort, reputably. Morality even is subordinated to comfortable living-called Complete Living. The theory opposed to this, as light to darkness, we have called the Real-humanistic. Its aim is not complete living but complete life. It may be summed up as character and culture. It seeks to define the life of man as that of a spirit which rises above its environment and seeks ideal aims, ethical, aesthetic, and religious, and a will formed to right conduct. But it does not, on that account, ignore the claims of a knowledge of the phenomenal world and of society and of man's relations to both. It assumes this as necessary alike to conduct and the highest spiritual life; but in the education of the people, as in the development of the man to his full manhood, it regards the knowledge of all that has to do with the body and with nature as merely contributory to true education.

The best reply to Spencer is Locke, although he was no idealist. And all I would say here is that, suppose we had a man with all the pigeon-holed acquirements that Mr Spencer would give him, we should say 'Now let us begin to educate him.' In fact suppose an anthropoid ape who had lost the divine gift of instinct and was endowed with the imperfect beginnings of reason instead, and Mr Spencer's system of 
education would be admirable. The literary, aesthetic, religious and even morality as an ideal system of perfection, are all decorative merely. The intelligent anthropoid ape's desire for decoration would be satisfied with coloured ribbons and straw which please the village idiot, and would rightly be postponed to material necessities. Man's function on earth, we believe, is to use his environment as a mere basis for higher things-the things by which men truly live, and these must from the first and all through, constitute the substance of his education.

Assuredly, we all hope never to be, and never to meet, that incorporation of the elements of all the sciences which Mr Spencer calls a man, even though endowed with the prudential bourgeois morality which by the help of the police keeps things going. A classical prig and pedant is bad enough, but, after all, he is in touch with the best in humanity: the prig pedant who has fed on the dry crumbs of science since he was a baby would be wholly intolerable. There is surely some other ideal of the completely educated man which carries us far beyond the sphere of "complete living" in the Spencerian sense. The total inadequacy of sense-realism to conceive such a theory will I think be well illustrated by turning to Mr Spencers special treatment of Moral Education which has not so far as I know been subjected to adverse criticism, attention having for the most part been directed to the intellectual part of his treatise.

But before doing so I would say that Mr Spencer's chapter on Method, although it is, perhaps because it is, a collection of recognized precepts lucidly and logically put, is well worthy of the perusal, both of teachers and theorists.

\section{Moral Education.-A Criticism.}

I heartily concur with $\mathrm{Mr}$ Spencer, both in the beginning and the conclusion of his chapter on "Moral Education." His first paragraph concludes with this utterance:- "The subject 
which involves all other subjects, and therefore the subject in which education should culminate, is the Theory and Practice of Education." We cannot, of course, teach boys and girls at school how to discharge their duties as parents : at the school age, such instructions could have no link of association with the knowledge and experience of the boy and girl, and would, therefore, be wholly futile. We teach children these, their future duties, by being ourselves an example to them, which they will remember and imitate: nothing in education is so potent as tradition early received. But when Spencer suggests that the education of young men and women should culminate in the study of education - that is to say, of moral educationI think he gives utterance to a novel idea, which is not to be set hastily aside because of its novelty. Perhaps it will one day be accepted as a truism - at least as regards young women. I remember, many years ago, being much impressed, but, of course, not surprised, when I beheld young ladies hurrying in considerable numbers to University lectures in Logic, Latin, Mathematics, and Physiology, while the subject which most nearly concerned the future life of more than ninety per cent. of them, viz., Education, was taken only by the few who meant to be school teachers. It will not always be so. Mothers of the wealthier classes will tell us that they have no time for the training of their children; the demands of society are too exacting to admit of it. The day will come, if the race is to make progress, when it will be the other way about, and "Society" will have to content itself with taking a second place, while the duties of the nursery and the parlour will make good their prior claim. If the mother, though never the sole, yet always (theoretically, at least) the chief educator, is unfit for these duties, as is too commonly the case, it is just as well that she should delegate them, for, as Spencer truly says, "The defects of children mirror the defects of their parents "- a remark to be extended, I need scarcely say, from the parent to the teacher. That the teacher who professes to be an educator should study education 
before he enters on his task would seem to be a proposition beyond all question, and yet it is still questioned by not a few survivals of a passing generation at Eton and elsewhere.

Mr Spencer adverts to the irrational severity of domestic discipline, but he omits the still greater evils which flow from the training which is irrationally indulgent. In this respect Locke takes a much firmer and more profound view of the relation between parent and child, though he errs in the excessive severity which lies at the foundation of his system of moral training. We are not to suppose that over-indulgence is limited to the well-to-do; it is even more common among the poorvaried, of course, with fits of passion. The following incident (a part of my own personal experience) sums up the attitude of the indulgent maternal mind :-

"Why do you not send your children to school?" said the minister to a fisherwoman in a Banffshire village.

"Because they dinna want to gang," answers the mother.

"But, surely, it is not what they want that you should think of, but what is good for them."

"Oh, puir things," retorts the mother, "they maun hae their ane wull, for it's a' we puir folk hae to gie them"!

So far, I say, we shall concur with Mr Spencer. But now he plunges into a sea of error, putting what he has to say, however, in a way so lucid, pleasant, and seeming-logical as to seduce the young reader into the acceptance of a fatal doctrine-a doctrine, moreover, which, if understood and held, degrades the position, by degrading the aims and work, of the educator. He discusses the end or aim of moral education, and the relation of this end or aim to an ideal morality and an ideal system of training. Adaptation to environment governs all he says in the moral, as it did in the intellectual, education of the young.

Here I shall let Spencer speak for himself before I proceed to criticize his position :

"Even were there methods by which the desired end [the 
practice of an ideal system of morality] could be at once effected, and even had fathers and mothers sufficient insight, sympathy, and self-command to employ these methods consistently, it might still be contended that it would be of no use to reform family government faster than other things are reformed. What is it we aim to do? Is it not that education, of whatever kind, has for its proximate end to prepare a child for the business of life-to produce a citizen who, while he is well-conducted, is also able to make his way in the world? And does not making his way in the world (by which we mean, not the acquirement of wealth, but of the funds requisite for bringing-up a family) - does not this imply a certain fitness for the world as it now is? And if by any system of culture an ideal human being could be produced, is it not doubtful whether he would be fit for the world as it now is? May we not, on the contrary, suspect that his too keen sense of rectitude, and too elevated standard of conduct, would make life intolerable or even impossible? And, however admirable the result might be, considered individually, would it not be self-defeating in so far as society and posterity are concerned? There is much reason for thinking that, as in a nation so in a family, the kind of government is, on the whole, about as good as the general state of human nature permits it to be. We may argue that, in the one case, as in the other, the average character of the people determines the quality of the control exercised. In both cases it may be inferred that amelioration of the average character leads to an amelioration of system; and further that, were it impossible to ameliorate the system without the average character being first ameliorated, evil rather than good would follow. Such degree of harshness as children now experience from their parents and teachers may be regarded as but a preparation for that greater harshness which they will meet with on entering the world. And it may be argued that, were it possible for parents and teachers to treat them with perfect equity and entire sympathy, it would but intensify the sufferings 
which the selfishness of men must, in after life, inflict on them.

" 'But does not this prove too much?' someone will ask. 'If no system of moral training can forthwith make children what they should be-if, even were there a system that would do this, existing parents are too imperfect to carry it out-and if, even could such a system be successfully carried out, its results would be disastrously incongruous with the present state of society-does it not follow that to reform the system now in use is neither practicable nor desirable?' No. It merely follows that reform in domestic government must go on pari pass $u$ with other reforms. It merely follows that methods of discipline neither can be nor should be ameliorated except by instalments. It merely follows that the dictates of abstract rectitude will, in practice, inevitably be subordinated by the present state of human nature-by the imperfections alike of children, of parents, and of society-and can only be better fulfilled as the general character becomes better.

"'At any rate, then,' may rejoin our critic, 'it is clearly useless to set up any ideal standard of family discipline. There can be no advantage in elaborating and recommending methods that are in advance of the time.' Again we contend for the contrary. Just as in the case of political government, though pure rectitude may be at present impracticable, it is requisite to know where the right lies, in order that the changes we make may be towards the right instead of away from it; so, in the case of domestic government, an ideal must be upheld, that there may be gradual approximations to it. We need fear no evil consequences from the maintenance of such an ideal. On the average, the constitutional conservatism of mankind is strong enough to prevent too rapid a change. Things are so organized that, until men have grown up to the level of a higher belief, they cannot receive it; nominally they may hold it, but not virtually. And, even when the truth gets recognized, the obstacles to conformity with it are so persistent as to outlive 
the patience of philanthropists, and even of philosophers. We may be sure, therefore, that the difficulties in the way of a normal government of children will always put an adequate check upon the efforts to realize it." Note now the "proximate end" of moral education, as defined by Spencer (p. 99), viz.: "to produce a citizen who is well-conducted, and is also able to make his way in the world," that is to say, "acquire the funds requisite for bringing-up a family." This "proximate end" he elsewhere identifies with the "practical ideal."

We at once quarrel with $\mathrm{Mr}$ Spencer's conception of the moral or ethical end. If he simply means that, try as we may, we ourselves shall never be able to lead ideal lives or train up others to lead them, he utters a commonplace which is all too true; but this is not what he means, as we may see from the rest of his argument. Although it may be that we must often enough be content with the attainment of a "proximate end," in the sense of an approximation to an ideal end, the approximation is not our end or aim. The proximate end, as conceived by $\mathrm{Mr}$ Spencer, has its value; but as an educational end it is contemptible, and would take the very heart out of any teacher worth his salt. There is such a conception as that of the ideal man: that is to say, the man to whom the great ethical ideas of justice, benevolence, integrity, purity, and the thought of God in whom all ideals rest, are a sacred possession, and who strives daily to make them the guide of his conduct, though they may often lead him to suffering, nay, sometimes to death. No man succeeds perfectly; but, that each may be even such as he is, it is necessary that he strive after something higher than his actual attainment or the practical ideal. In the ideas resides the imperative moral law, and it is this the true man would fain, by God's help, fulfil. The fulfilment of the law in the ideas is the spiritual life-the true life of a rational spirit; all else is life inadequate and imperfect. This true life is, for each, simply the completion of himself as man. All created things tend unconsciously or 
consciously, through the forces within them, to their own fulfilment or completion, while the self-conscious man purposely endeavours to realize that fulfilment in himself, if he is to be truly man. This, I submit, is the true doctrine; and it is to this we have to educate children and youths; and if we fail, accept our failure. It is also, substantially at least, the doctrine of Plato, Aristotle, and the New Testament.

I must assume that you have read the relative passages in Spencer. If you have, you will have learned that the young must not be trained to seek and serve the ideal, but for the "world as it now is." If too good for it, or trying to rise above the average, first the child, then the youth, and finally the man will suffer. We must abjure the highest, because it leads to possible pain-this pain having chiefly or wholly to do with our "getting on." We must not try to be better than our neighbours. If a youth has ideals of conduct, he must keep them under lock and key. They are too good for daily use. He had better, I should say, expunge them from his mind altogether, lest he should inadvertently act in accordance with them. His best course would be not to deny their existence, but to write them on a card, and hang them on his walls, to be read over-say, on birthdays; but, when he has read them, he must, with a cynical smile, exclaim: "All these I shall not observe from my youth up. These are the solid coins of fools, but only the counters of wise men-in this sense: that the wise do not deny their absolute truth as symbolic of something or other which is real and true ideally, but they must not treat these idealities as realities here and now in this world. They are for some other place and time."

This is no misrepresentation of our author, for he admits that there is a true ideal; it is to be known to us that we may be aware "where the truth lies," and to guide us in making cautious and calculated changes in the right and true direction; but that is all. You may live, more or less, according to an ideal standard, and teach others to live according to an ideal 
standard, but only in so far as it does not separate you and others too far from the common motives that govern the average man. Out of a kind consideration for those who have an ideal standard, Spencer condescends to say, that if we only work in the direction of it, without trying too hard, "we need fear no evil consequences"! (p. IOI). Such, according to Spencer, is the moral aim generally, and such the place and dangers of the ideal.

I would remark that this practical ideal of Spencer's is not an ideal at all. There cannot, if there is any meaning in words, be two ideals. 'The practical ideal, which he commends, is the ideal; the other ideal - what we should call the ideal-is with him so remote as to be little better than an illusion. What reality can there be in that which cannot be used?

"Let us now," he says, "consider the true aims and methods." But there is confusion here, for he has already given us his true aim, which is that a man shall be trained "to be no better than he should be," to use a phrase which is strictly true of Spencer's aim, and conveys also its criticism.

Spencer has already, I repeat, got his aim or end in the sphere of moral education, and what he now proceeds to consider are the methods whereby we may attain that aim or end-how we are to train children to be as good as their neighbours, and prevent their being any better, lest "evil consequences" should follow. But he is, very naturallyindeed, necessarily, when he begins to think of method-led aside for a moment to consider the final standard or criterion of all morality whatsoever. $\mathrm{He}$ has already said, remember, that our approximate end, as he calls it, is to produce a wellconducted citizen, who "can make his living," etc. That there is an ideal greater and higher than this, however, he admits, but he sets it aside as if it were the dream of enthusiastssomething we may as well know, that our conduct generally, and our teaching generally, may tend that way, so far as it 
is quite safe. There might, he grants, flow "evil consequences" even from merely keeping ideals in view; there is some danger in this, but he trusts to human wickedness and weakness to obviate these evils. That is to say, the evil in men may be trusted to obviate the evils arising from the pursuit of the ideal good-a singular position! There is manifestly something hopelessly mixed here, to say the least. The evil in man is to be relied on to keep him safe from evil-a remarkable assertion! We wonder what the author can mean by "evil," and in what sense he uses the word.

And he must sympathise with the wonder of his reader, for he proceeds to consider how the (dangerous) true and absolute ideal in life and conduct is ascertained. By what mark shall I know it when I see it? What is its criterion? Important this, because it may not only make the whole argument logical and coherent, but also, perhaps, suggest a method of procedure in educating the young. The criterion or standard he seeks is thus propounded: that conduct is right and good "whose total consequences are beneficial"; and by the word 'beneficial' he means "resulting in happiness." This is the way (we are told) we find the true-the moral ideal.

But as he has already said that we must not make the ideal our aim in educating, but that our aim should rather be the adapting of the young to the time and circumstances in which they live-a training of them to a kind of average morality which sets aside the ideal and perfection as idle dreams-the standard of the said ideal which he now exhibits to us lands him in endless contradictions. If the ideal is that whose total consequences are most pleasurable and beneficial, then, surely, we ought always ourselves to aim at the "most pleasurable and beneficial," in other words, the true ideal, and train the young to do so; for, if we do not aim at it, we shall be aiming at something which is not pleasant and beneficial, or, at best, only in a minor and subordinate degree pleasant and beneficial. To do what is most pleasant and beneficial to you 
as a man, would, inasmuch as it is the true ideal, be unpleasant and unbeneficial! Has he not already virtually said, "Be not too good, lest you suffer in this unsatisfactory world"? And now he tells us that the goodest goodness is the pleasantest thing going. How, then, by pursuing this goodest goodness-this true and absolute ideal-can I suffer-at least in the moral and spiritual sense? Why should I content myself with hanging up ideal principles on the wall, and suspending them in my daily conduct? How, in short, can that which is "pleasant and beneficial" be undesirable, according to Spencer's theory of morals? Not to aim at the "ideal" is to aim at that which is not pleasant and beneficial, according to Mr Spencer's own theory, or, at least, not so pleasant and beneficial as the ideal, by his own showing, is. This is a singular result of the happiness theory of morals. He would rejoin, doubtless, that the practical ideal it is which contradicts the true ideal. Men are not yet ready for the pleasures of the true ideal; it would be painful to them, not pleasant; striving itself, in fact, is unpleasant ; therefore, don't strive.

Now, I do not think we can let such an argument pass without protest. If the true ideal is the most pleasurable in its consequences, it can have been ascertained only by experienceif not the experience of everybody, yet the experience of Mr Spencer and other thinking men. If so, then it is surely his duty to educate to this "highest pleasure," this true ideal, and not to allow his fellow-men to go on living without even trying to get the "greatest pleasure." Doubtless, he might reply: "I cannot admit the duty, because I know very well the mass of mankind cannot rise to such enjoyments." Then, we say : Why talk about the true ideal at all, and dangle it before their eyes as a thing first to be looked at and then to be looked away from? For, if it is the highest pleasure, it can exist to their consciousness at all only in so far (according to your criterion) as it is conceived as the highest pleasure - the ideal. For the ideal and the highest pleasure are interchangeable terms. 
Accordingly, it can only add to their pain, not their pleasure, to see the highest pleasure, and then to be told to rest content with the lower pleasure, as best suited to them. And, again, if they pursue the lower pleasure, as best suited to them and their environment, this must mean that they get more pleasure out of the lesser pleasure than they could out of the so-called greater pleasure. Their ideal is, in short, the lesser pleasure, and they have as much right to call it the true ideal as you have to call the scheme of life hanging on the wall the true ideal. "So long as they are happy, what's the odds?"

True, Mr Spencer might say: "I do not try to teach what I regard as the highest pleasure, the true ideal, to children and men because I would not disturb them in their greatest pleasure [beer and skittles], though it is really painful to them more than they know; but to pursue the true greatest pleasure, the true ideal, would be more painful still." Then, may I not rejoin, neither the true ideal nor the pursuit of the true ideal is so pleasurable to them as their own lower ideal, and (according to you) greater pain? That is to say, they already have the true ideal, and not you at all. They have summed up one way, and you have summed up another; your criterion or standard is manifestly no standard, for a standard is not a standard unless it is a fixed something by which all else can be measured. Pleasure and pain, we may conclude, are not the criteria of virtue and vice.

Another answer to the question, "Why do you not train men to the highest pleasure, the true ideal?" might be this. Mr Spencer might, quite consistently, say that he did not try to teach men the highest pleasure, the true ideal, because it was such a bore to him. In other words, the mere labour of doing so was a pain greater than any pleasure that could come out of it to him, and, as detracting from his pleasure, detract consequently from his own ideal moral state. In brief, to attempt to convert men to his ideal, he would, in his ozen person, be untrue to the standard of all morality - the greatest 
sum of pleasure; nay, inasmuch as it would be purposely done, he would be profoundly immoral in so acting, so far as his own ethical completeness was concerned. Nay, further, knowing, as he did, the pain they would suffer from pursuing his ideal, his purpose would be a purpose of evil-at best, a doing evil that good might, perhaps, come. But, surely, we ought not to be afraid to teach men the true ideal-the most pleasurable; for has it not been already said that, men being so wicked and weak, we need not anticipate any "evil consequences" from keeping the ideal in view. This ought to console us, and encourage us in teaching the true ideal. "Do not hang back," he might say, "for the pursuit of that which is absolutely pleasant and beneficial (the true ideal) will not result in evil consequences (i.e. the unpleasant and unbeneficial) so much as we might fear (!), because men have such a strong natural bias to the unpleasant and unbeneficial."

It is assumed, remember, all this while, that there exists a true moral ideal ; it is distinctly stated that that moral ideal yields the maximum of pleasure, and is finally to be tested by its power to do so; but we are to set it aside in favour of the relatively right and good-the practical ideal-of that which shall make us good enough, and no more, for the society into which we are born. In other words, we are to adopt as our standard the less pleasurable and the less beneficial meanwhile, in order that we may secure the maximum of pleasure obtainable now and here-London, 1902-the maximum possibile varying as we may happen to be in England or France or Syria or India or China. Why are we to do so? Because if a man aimed at true and genuine pleasure and happiness, and so lived, or strove to live, the true ideal life, he would, inasmuch as his "sense of rectitude" would then be too keen and his standard of conduct too "elevated" (p. 99), fail to secure the greatest pleasure and benefit; therefore, the standard of conduct is never that which would yield to a man the greatest pleasure and benefit, but that which would, taking all his circumstances 
into consideration, yield the greatest pleasure and benefit in his own judgment at the moment. As it is absurd, in such a case, to suppose a man not choosing the greater pleasure, we may be sure he always does so; consequently, every man is always moral, always in harmony with his ideal, i.e., his greatest pleasure and happiness at the time.

And yet there can be no doubt that Mr Spencer does actually believe in a true moral ideal which, though measured by pleasure, is different from a "practical" ideal also measured by pleasure. But, if we are to measure conduct by the sum of the pleasurable which it yields, and not by law, how can any ideal be truer than another? Mr Spencer has no right to speak of a true ideal which shall be a standard for all ; one man's ideal is as good as another's if it happens to be the greatest pleasure for him, which we may always presume it is, for why should he not choose pleasure? What prevents him doing as he pleases, unless it be the policeman? But although Mr Spencer has, in my opinion, no philosophical right to speak of a true ideal, he yet does so, and sets this true ideal against the practical ideal. The former, Spencer evidently quite honestly holds to be truly morality as being the true ideal; the latter, then, is not morality at all, but an approximation, an adaptation of some of the truths of morality to the average of a particular time, place, and circumstance. This latter is always at war with the former - the true ideal - and our business is, according to Mr Spencer, after taking a passing glance at the impossible true ideal of conduct to educate ourselves and others in that which is not too moral-that is to say, not too pleasure-giving, not too beneficial in its results!

It is manifest, then, that the "practical" moral ideal, which is to be the working ideal of teacher and parent, is a gathering together of the dubious and admittedly defective, untrue, and pain-giving principles which regulate the Church, the Market, and 'Change, and training our children in these. Be just, but not too just ; be benevolent, but not too benevolent; be self- 
controlled, but not too self-controlled; be pure, but not too pure; be virtuous, but not too virtuous; be good, but not too good : this is the working ideal.

Where, then, can the true ideal-the just, the good, the noble, the heroic, the self-sacrificing, and so forth-be all this while? In Spencer's view, doubtless, as well as in ours, this ideal is in the thoughts of all the wise of all ages, who have preached it and pressed it on men, not altogether in vain. Have they been wrong to preach it as yielding a scheme of conduct? If not, are we wrong to teach it? Shall we deliberately counterwork it? Shall we set aside Christ and Paul, and all the philosophers and poets, and say to them, "Go to, do not interfere with our practical teaching; do not fill our children's heads with ideal nonsense. We have to prepare for the world that now is, and the world is to him who can take it; and he alone can take it who sands the sugar of his justice, who waters the milk of his human-kindness, who mixes his truthfulness with prevarications, his wisdom with cunning, his self-sacrifice with selfishness, his reverence with impudence, his nobleness with ignobleness, his virtue with vice, his good with evil." If Mr Spencer does not mean this, what does he mean? Do you not feel that there is an error somewhere, that $\mathrm{Mr}$ Spencer and his school either use language in a non-natural sense, or that they are hopelessly wrong in their attempts to give the philosophy of the moral and spiritual life of man? The maximum of pleasure, now and here, is to be your aim, and you are not to bother yourselves or your pupils about the true ideal (the most pleasurable, note), save by a passing allusion to what is essentially an illusion. Now, to compare such teaching as this of Spencer's with that of Greek or Roman thought, would be an insult to the latter. Nay, even the educated Chinaman would abjure it, and as to Christianity, what shall we say? Is this the teaching of Christ? And yet our training colleges exist as Christian institutions. The Churches are eager to take Government money to conduct these colleges 
in order that, at the very fountain-head, they may guarantee Christian teachers and Christian teaching; and this is the book $^{1}$ which those who are shortly to be placed in a position of authority over the coming generation are told to study as if it were a Gospel-a new evangel to English men and women. In one room the Churches teach Christ, and in the other Spencer-Christ the teacher of Divine law, the preacher of transcendent ideals, the priest of self-sacrifice. I do not doubt that the training college authorities, generally at least, try to counteract this teaching; but is it wise to give young and wholly unformed minds such a foundation for their philosophy of life?

According to Spencer, Christ on the cross, and all the crucified and self-sacrificed martyrs, were enjoying the greatest sum of pleasure possible for them. I ask you: Is this the true reading of history? According to Spencer, it was foolish of Christ and the others; they were mistaken. They were blind to their environment. Unadapted to their environment they did not "survive." Mr Spencer might, perhaps, admit that they were nobly blind; but he must at heart despise their intelligence, and denounce their blunder. No wonder the people mocked at them and went off self-complacently to their beer and skittles - their greatest sum of pleasure, and, therefore, as moral and as lofty as the faith of the martyr on the cross or the rack. Alas, for Christ and the others, who misprized the common pleasures of life ; they had made a mistake in arithmetic. 'That figure there on the board, running into the thousands, with a fraction (a circulating decimal, and a little elusive), represents pleasures; it has to be divided by something called the "sum," and these mistaken martyrs brought out a wrong quotient.

It would be out of place here to enter further into philosophical argument than we have done. But, speaking generally,

1 It is no longer specially recommended. 
I may say that the Christian faith (it matters not to what extent men may differ regarding facts and doctrines) always includes this ethical substance, viz. the innate instincts and needs of man's nature, as a complex of feeling, tendency, emotion, and reason, yield to us, in the long-run, certain ethical ideas-for example, truthfulness, benevolence, justice, integrity, purity, self-sacrifice, and so forth; these ideas, in their highest and purest form, constitute the law of our nature-the law of God in us. It matters not that these ideas may have taken generations to grow, if they are the true reading of the moral and spiritual nature of man. It is precisely these ideas, in their most generalized and universal form, with Divine law inherent in them, that constitute the ethical ideal ; and up to this we have ourselves to strive, and up to this we have to educate the young. The process by which we educate them we call training to the good, and discipline to duty ; and the question of method, which so much concerns us as teachers, is simply an inquiry into the "way" whereby we may build up this ethical ideal in the minds of children and youths, and make it the motive force in their conduct of life, as at once the law of God and alone the true life of man on earth-here and now. This brings us to the question of method, as dealt with by Mr Spencer.

As might be expected, his method is the method of consequences. We accept this. In our own adult case, however, the consequences of misconduct are the inner pain of sentiment ignored, of a foregone ideal, of a broken law, of an outraged nature, of God defied; and in the case of the young, the pain of the disapprobation of teachers and parents, as embodying for the young the ideal and the law. Material consequences may or may not follow - that is to say, the punishment of the body in various ways, direct and indirect, positive and negative. Whether they should ever follow is one of the debated questions. 
You will see that, even to train up children to be no better than they should be, and always to choose what yields the most pleasure, some method is wanted. They have to be taught wherein their true pleasure lies when they are men, although it may seem not to be their true pleasure when children, because of their immaturity of judgment. How are we to proceed? Doubtless, if we may make a reasonable inference from a statement in the beginning of the chapter, Spencer would say, along with all other educational moralists, "By example." But, outside example, some other mode of procedure is necessary. This mode of procedure is called a method. Now, it is manifest that if morality is identical with the most beneficial or pleasing consequences, I must train to morality by painful consequences. The child-sum of pleasures must be rectified by the adult-sum.

Mr Spencer points out, I have just said, that the method is the method of consequences; but the consequences are, in the larger part of his argument, always material, not moral-with the boy, the pain of burning his finger or having to put right what he has put wrong; with the man, indigestion or the pain of being deprived of his salary or the injury to his prospects of salary. Thus, he says, the child and the youth attain to a "knowledge of right and wrong by personal experience of good and bad consequences."

If I amuse myself by sticking a pin into my leg, I feel pain, and I seek some other amusement in future. There is here what Spencer calls a "natural reaction"-that is to say, nature instantaneously punishes an infraction of nature's laws. Spencer's main proposition, then, as regards method of moral training is, let the reaction of nature take place. Now, it is not morally wrong to stick a pin into my leg. It is merely a physical miscalculation. Mr Spencer confounds moral and emotional with purely physical reactions. When a little boy, in his anger, smashes his mother's best china-bowl, the natural reaction is a feeling of great satisfaction. When he burns his 
catechism in the hope of so ending a painful series of daily lessons, the flames are less bright and joyous than those that blaze up in his own heart. This is, as a matter of fact, the natural reaction. Then, again, when he climbs a tree, and falls and breaks a leg, the natural reaction of his being such a goose as to lose hold of one footing before he has secured the next is manifest. He has broken a physical law, but not a moral law, and must take the physical consequences. If he has taken firm hold, and secures the object of his ambition-the thrush's nest-and sells the eggs for $6 d$. apiece, he now enjoys the natural reaction, as before he suffered from it. It is quite clear from these illustrations that "natural reactions" are outside the moral sphere altogether, and that if there be anything immoral in his act, it must arise in some other way. In what way? It arises from the fact that he has broken a moral law; and that moral law can only be to a child the command of his parents and teachers. What, then, is the natural reaction? Spencer gets so confused over his natural reactions that he begins, towards the end of this chapter, to see that he is somehow wrong, and says that the disapprobation of the parent or teacher is itself a "natural reaction." Here he is at last on the right scent. But what becomes of his original "natural" reaction? The natural reactions he has been talking of are the reactions of nature in the sense of physical laws. He would now include the parent's disapprobation under the same head, using the word "natural" in the vulgar sense of what might be "reasonably expected to follow." I see my boy in the tree where he has been told not to go. Am I cunningly to shake it, that I may cause him to fall and break his leg, and so facilitate the natural reaction? IVhat natural reaction-the reaction of physical law or of moral law? Is this to be his punishment, a fall that breaks his leg, and to which I have cunningly contributed? I think not. The parent who did it would soon be in the hands of the police.

In fact, the much-lauded doctrine of natural reactions in 
the sense of reactions of physical law, carries us a very little way indeed. At best it is a physical reaction to a breach of physical law. We are compelled from the first to consider moral reactions for moral offences, and let the physical blunders correct themselves, after we have given due warning.

No parent or teacher needs to be told that ninety-nine per cent. of the wrong-doing of the young is, not a breach of physical laws, but simply disobedience-the breach of moral law as that is centred in the parent or teacher, the moral authority set over them. There would be no natural reaction (i.e., no material consequences) at all in the great majority of cases of wrong-doing, and the majority of the remainder would be pleasant were it not for the purposed intervention of the parent or teacher, who deliberately inflicts certain unpleasant material consequences under the name of punishments. And $\mathrm{Mr}$ Spencer himself is compelled to admit that this is so, for when he leaves certain little childish faults behind him, he virtually admits that he is on the wrong track, and has to rest the training of the child on the simple approval or disapproval of the master or parent, with such punishments, if any, as they may choose to inflict. There is no other course open to him. In the sphere of child-morality there is no "natural " reaction available, except approval or disapproval. But if this is so in all important cases, it is equally true of the unimportant. The child who makes a litter (to take Mr Spencer's illustration), and is required as a punishment to put things right, is not morally educated by that, but by the disapproval of his mother, who emphasizes her disapproval by imposing this task-a course of conduct on her part to be justified by the fact that it impresses her disapproval and puts it in a concrete form. Again, the restitution of a stolen knife, or of the knife of another lost through carelessness, does not give rise to any moral feeling; that moral feeling must precede the restitution, this latter being only the outward and visible sign of an inward spiritual grace. So the boy, of whom Spencer speaks, who, having been kindly 
and generously treated by an elder, declines to do a kindness to him in return, and, when he finds the consequences of it in the elder refusing to amuse him any more, then, and not till then, of his own accord brings him his shaving water and boots in order to restore friendly relations, has gone through no moral training at all, except in so far as he first felt the disapprobation of his elder, and, feeling that, felt his own unworthiness, and then tried to make amends. And what does Mr Spencer himself say of the father who has the "perfect confidence and affection of his children"? He says that the said father finds that the " simple display of his approbation or disapprobation gives him abundant power of control." Of course it does. But is this the calculation of material consequences by the children? If so, they are mean and demoralized little monsters.

Thus the method of Spencer, no less than his end and criterion, breaks down all round, even taking him on his own showing; and, in so many words, he has to tell us at last what he ought to have told us in the beginning, that the disapprobation or approbation of the teacher is itself a "natural reaction," and this is not a reaction of nature at all, but a moral consequence. Mr Spencer, when he gets on the right track, begins to talk of sympathy between parent and child, and the power of approbation and disapprobation where this sympathy exists. With all this I believe we should all substantially concur, as well as with his remarks on the importance of not expecting children to be too good, and so forth. But as regards the moral end, the moral aim, the moral motive, the moral criterion, and the moral method, his doctrine is always wrong, and sometimes pernicious. Then, when he begins at last to see light, in the course of his fluent argument, instead of tearing up his MS. and beginning over again from a new and higher point of view, he involves himself in intellectual confusion and moral contradiction, as he did when he spoke of true and practical ideals.

The old doctrine of "natural reactions," which Mr Spencer 
fathers anew, simply amounts to this: "We see how nature inflicts a physical penalty for a breach of physical law ; if, then, we desire to inflict a physical punishment over and above the moral penalty, so as to emphasize the breach of moral law, let us take a hint from nature, and let our physical punishment, as far as possible, have some relation to the physical character of the moral offence. It is not a method of moral education at all; but simplya Rule to guide us when we find it necessary to mark, in an external way, our disapproval or condemnation-the disapproval being the essential punishment, and the gain of that disapproval being the stirring-up of a moral emotion in the breasts of the young. Even as a rule for our guidance in carrying our moral disapproval out into painful material consequences, the method of natural reactions is of very restricted application. Bentham's word is much preferable. Let the punishment, he says, be "characteristical." It is the voice of moral authority, and the force of example in the parent and teacher, that teach morality. In brief, and without dwelling longer on the subject, I repeat that the whole principle of natural reactions does not touch the theory of punishment for moral offences, but at best only gives a rule for the selection of physical punishments when we have once made up our mind, on moral grounds, to inflict them, and then, if possible, they should certainly be "characteristical."

I would impress the futility of the so-called method on you with a few additional remarks. It is evident enough that, following the rule of natural reactions without considering moral elements, we should constantly be led into blunders. When a boy breaks a wine-glass through carelessness, we might say that he should be required to replace it ; but "nature" does not require this, and to insist on it would be unjust. If he is the son of poor parents, and makes great efforts to economize, with a view to replacing it, he does so because of his feeling of sympathy with his parents in their loss, and of vexation with himself, as having inadvertently caused a loss. The replace- 
ment, then, is a moral act pure and simple, and has nothing to do with nature's reactions. If, again, he has broken the glass intentionally, in order to pay his parents out for some imaginary injustice, there is no natural reaction of replacement, but quite the reverse. He would like to break two glasses. This is the natural reaction ; and, if I wish to correct the boy, I must first get him to feel what the good boy, who inadvertently broke the glass, felt, and, out of the strength of that feeling, condemn himself, and seek to make restitution. Bentham's recommendation is a sound one, because, among other advantages, it admits of our bringing in reason and common-sense to control nature's reactions, which are generally irrational. A good thing it is that we have to determine punishments, and not nature; for nature is blind, and stupid, and often cruel. Spencer says that natural reactions are "pure justice." On the contrary, they very seldom are justice at all, if men do not guide and control them. Natural reactions are constantly too slight for the offence, more frequently too grave. Two boys are clambering over a high wall. They have no right to do so, but "boys will be boys," and one falls and breaks his leg; the other falls, and escapes with a slight bruise. Which of them has been justly treated by nature? Both boys will certainly be more careful in future, but the boy who broke his leg will, perhaps, be, ever after, afraid of high places. This, surely, is an unfortunate result. Courage is a virtue. By over-severity, nature has extinguished the growth of a possible virtue. An infant puts his finger into a candle-flame. Surely, the punishment of hours of pain is too severe. In truth, nature is a very hard task-master, and if we were to follow her example we should often be most unjust. A boy snaps the blade of his knife through carelessness. Let him be punished by going without a knife, Mr Spencer would say. This may be called a natural reaction, but why should I permit nature to inflict it? I have to consider the boy's motive. What is there that is morally wrong in snapping the blade of his knife through carelessness? 
I should say, regret the incident with him, and give him a shilling to buy another knife. If there is anything wrong in the snapping of the blade, it must have been that he did it purposely, or while using it for some purpose forbidden by you. The wrong then is breach of law imposed by authority. So with a child littering the floor. Punish by making the child set everything in order again, says $\mathrm{Mr}$ Spencer. But why punish at all? There is nothing wrong in littering the floor; it is a very innocent and very pleasant and seductive amusement. The natural reaction is a disposition to make the litter greater than ever, that the joy may grow with the mess. The wrong exists only if you, the parent, have forbidden it. Here, again then, the wrong is against law as imposed by anthority. Mr Spencer has exaggerated the range and misinterpreted the meaning of nature's reactions. In the whole of moral training it is the motive of the child's act that you have to consider; other offences due to thoughtlessness or redundancy of animal life must be kept outside the moral sphere and gently dealt with.

One of Mr Spencer's punishments shows, in an amusing way, how little he has realized the difficulties of the teacher and parent: "Stop pocket-money," he says. How many boys have any pocket-money to stop? It is as if you were to pass a law to punish thieves by increasing their income-tax.

One excellent result, however, it seems, would flow from Mr Spencer's doctrine. He tells us that parents, having to reflect, after a misdemeanour, as to the proper natural reaction applicable to that particular misdemeanour, would learn selfcontrol, and no longer punish impulsively. This is like telling an angry man to count twenty before he speaks. It manifestly assumes that the parent already sees the importance of selfcontrol, and desires and endeavours to exercise it. If he does, the end is gained without the help of the necessity of considering natural reactions. He cannot consider these until he has first controlled himself. 
I would, in conclusion, point out that Mr Spencer's method is a method of merely negative training in morality ; not a word is said about positive training. Negative training can repress the external exhibition of a vice, while the vice itself may be more deeply rooted than ever. I say there is no positive training to moral ideas, and to a habit of virtue: but with Spencer's moral theory how could there be? The theory is: Do so-and-so or you will suffer; you will get the minimum of pleasure and the maximum of pain, and the maximum of pain is vice. Accordingly you cannot train except negatively, if you are to work out this theory consistently. And negative training will produce only negative results.

I hope that these critical notes have made it clear: (I) that Mr Spencer's ideal aim in education is false: (2) that his standard of morality is false : (3) that his "method" of moral education is nothing save a Rule to help you in selecting a punishment in certain cases; and that of very restricted application: (4) that, while there is much sound practical advice scattered throughout the chapter, the whole argument is as confused as it is misleading and pernicious, until he comes to the moral instrument of approbation and disapprobation, as resting on sympathy: (5) that the Spencerian moral training would be exclusively negative and deterrent training, and only incidentally and uncertainly secure the positive results at which the parent and teacher alike aim. For the attainment of this, not for punishing error, we want a method-a method which shall have for its aim the true ideal; for, we are assured by Quintilian and all the wise, that we can reach any height worth reaching only by striving to reach the top of the hillnot by sitting down despairingly at the foot of it or building a hut with a good kitchen and comfortable bed one-third of the way up. 



\section{BY THE SAME AUTHOR.}

The Institutes of Education. 2nd ed.

OLIVER AND BOYD, EDINBURGH.

Primary Instruction in relation to Education. 6th ed. OLIVER AND BOYD, EDINBURGH.

Language and Linguistic Method in the School. $4_{\text {th }}$ ed.

OLIVER AND BOYD, EDINBURGH.

The Training of Teachers and Methods of Instruction. 2nd ed.

THE UNIVERSITY PRESS, CAMBRIDGE.

The Life and Educational Writings of John Amos Comenius. 6th ed.

THE UNIVERSITY PRESS, CAMBRIDGE.

Historical Survey of pre-Christian Education. 2nd ed. LONGMANS, GREEN AND CO., LONDON AND NEW YORK. 


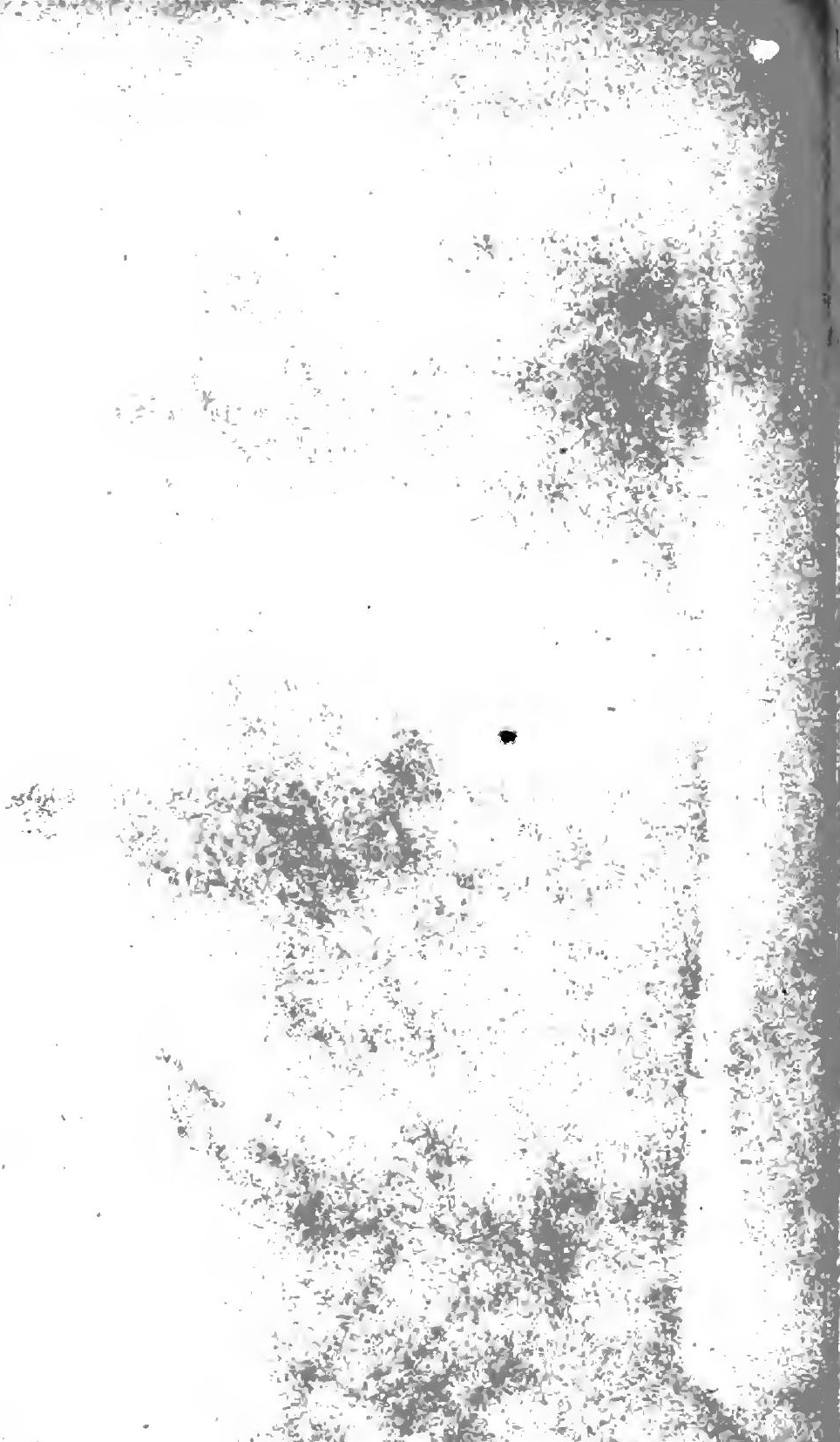



University of Cailomla

O5 HIITRN REGIONAL LIBRARY FACILITY

405 Hilgard Avenue, Los Angeles, CA 90024-1388

Return this material to the library

from which it was borrowed.
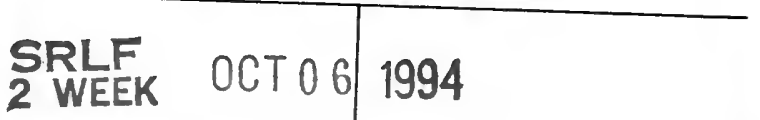

\section{THE LIBRART ONIVERSTIY OF CALIFORIN" LOS ANGELES}




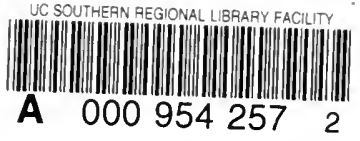

:

$-4$ 


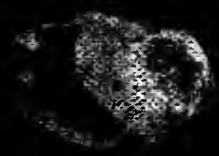

Uni 